\title{
Efeitos da nutrição na atividade cíclica reprodutiva e nas concentrações plasmáticas de melatonina em ovelhas mantidas em pastagem e submetidas ao efeito macho durante 0 anestro sazonal
}

\section{Aya Sasa}

Dissertação de Mestrado depositada na Seção de Pós-Graduação da Faculdade de Zootecnia e Engenharia de Alimentos da USP , como parte dos requisitos para a obtenção do Título de Mestre em Zootecnia, na área de Concentração: Qualidade e Produtividade Animal.

Orientadora: Profa. Dra. Lia de Alencar Coelho 


\section{Efeitos da nutrição na atividade cíclica reprodutiva e nas concentrações plasmáticas de melatonina em ovelhas mantidas em pastagem e submetidas ao efeito macho durante 0 anestro sazonal}

\section{Aya Sasa}

Dissertação de Mestrado depositada na Seção de Pós-Graduação da Faculdade de Zootecnia e Engenharia de Alimentos da USP, como parte dos requisitos para a obtenção do Título de Mestre em Zootecnia, na área de Concentração: Qualidade e Produtividade Animal.

Orientadora: Profa. Dra. Lia de Alencar Coelho 


\section{FICHA CATALOGRÁFICA}

preparada pela

Biblioteca da Faculdade de Zootecnia e Engenharia de Alimentos da Universidade de São Paulo

Sasa, Aya.

S252e Efeitos da nutrição na atividade cíclica reprodutiva e nas concentrações plasmáticas de melatonina em ovelhas mantidas em pastagem e submetidas ao efeito macho durante o anestro sazonal / Aya Sasa. -- Pirassununga, 2002.

Dissertação (Mestrado) -- Faculdade de Zootecnia e Engenharia de Alimentos, Universidade de São Paulo. Departamento de Zootecnia.

Área de concentração: Qualidade e Produtividade Animal. Orientador: Prof ${ }^{\mathrm{a}} \mathrm{Dr}^{\mathrm{a}}$ Lia de Alencar Coelho.

Unitermos: 1. Anestro sazonal 2. Ciclo estral, progesterona 3. Ovinos, efeito macho 4. Ovinos, raças 5. Ovinos, suplementação 6. Reprodução, melatonina I. Título. 
A meus pais Hiroyoshi e Sumiko, E a Eduardo Cavaguti,

Dedico 


\section{Agradecimentos}

À Faculdade de Zootecnia e Engenharia de Alimentos da Universidade de São Paulo, pela oportunidade de realização da graduação e neste momento do Mestrado.

A CAPES pela concessão da bolsa de estudo.

A Prof ${ }^{a}$. Dr ${ }^{a}$. Keico O. Nonaka, pelo auxílio nas dosagens hormonais

Ao Prof. Dr. Paulo Roberto Leme pela colaboração no manejo nutricional dos animais.

À Prof ${ }^{a}$. Dr ${ }^{a}$. Catarina Abdalla Gomide, Rose e Rosilda pela atenção e contribuição nas análises bromatológicas.

Ao Prof. Dr. Edson Ramos de Siqueira pela doação de parte dos animais que constituíram o projeto.

Aos funcionários Ricardo e Mané, pelo cuidado e atenção com os animais, e auxílio sempre que necessário.

Aos funcionários Antônio Piovato e China pela cooperação e atenção, sempre que possível, com os animais.

Ao Prof. Dr. João Alberto Negrão, pela concessão do laboratório para processamento das amostras.

Ao Prof. Dr. Antônio Joaquim Rossini, pela concessão das instalações que alojaram os animais .

A funcionária Alessandra pelo auxílio nas análises de OPG.

Ao zootecnista e amigo Eduardo Cavaguti pelo auxílio e ensino da parte nutricional

A Prefeitura do Campus de Pirassununga (PCAPS) da USP, pela concessão do pasto.

A Nadja, pela colaboração e auxílio na língua Inglesa.

Aos amigos que fizeram deste tempo uma estada melhor, e em especial ao Ricardo Hotta (Fimose) pelo auxílio infinito na parte experimental e pela demonstração de amizade.

A todos que de alguma forma contribuíram para esta realização pessoal e profissional.

Agradecimento especial à Profa. Lia, que mais uma vez me orientou, recebendo-me de braços abertos. Obrigada, pela paciência, atenção, amizade e confiança depositada em mim. 


\section{LISTA DE TABELAS}

Tabela 1 Valores bromatológicos do concentrado comercial utilizado no tratamento 1 (suplementação).

Tabela 2 Análise bromatológica do capim Panicum maximum cv. Aruana no início e meio do período experimental.

Tabela 3 Coeficientes de variação intra-ensaio dos ensaios hormonais (RIE) para a progesterona.......

Tabela 4 Coeficientes de variação intra-ensaio dos ensaios hormonais (RIE) para a melatonina.

Tabela 5

Delineamento experimental para o ganho de peso total, de ovelhas Santa Inês, Romney Marsh e Suffolk.

Tabela 6 Delineamento experimental para o número de dias para retornar a atividade cíclica reprodutiva após introdução dos machos em ovelhas Santa Inês, Romney Marsh e Suffolk.

Tabela 7 Delineamento experimental das concentrações plasmáticas de melatonina do período 1 (antes do início do tratamento em 22/09/2001) de ovelhas Santa Inês, Romney Marsh e Suffolk.

Tabela 8 Delineamento experimental das concentrações plasmáticas de melatonina do período 2 (antes da introdução dos machos em 20/10/2001) de ovelhas Santa Inês, Romney Marsh e Suffolk.

Tabela 9 Delineamento experimental das concentrações plasmáticas de melatonina do período 3 (final do período experimental em 01/12/2001) de ovelhas Santa Inês, Romney Marsh e Suffolk.

Tabela 10 Delineamento experimental para a duração da secreção de melatonina do período $3(01 / 12 / 2001)$ de ovelhas Santa Inês, Romney Marsh e Suffolk.....

Tabela 11 Delineamento experimental para o horário de início da secreção noturna de melatonina no período $3(01 / 12 / 2001)$ de ovelhas Santa Inês, Romney Marsh e Suffolk.

Tabela 12 Delineamento experimental para o horário de término da secreção noturna de melatonina do período $3(01 / 12 / 2001)$ de ovelhas Santa Inês, Romney Marsh e Suffolk.

Tabela 13 Resultado da análise de variância para o ganho de peso de ovelhas das raças Santa Inês, Romney Marsh e Suffolk dos tratamentos de suplementação e não suplementação durante o período experimental $(18 / 09 / 2001$ a 01/12/2001).

Tabela 14 Médias e desvio padrão do ganho de peso total de ovelhas Santa Inês, Romney Marsh e Suffolk, sob regime de pastagem, submetidas ou não à suplementação.

Tabela 15 Médias e desvio padrão do ganho de peso total de ovelhas de diferentes raças, sob regime de pastagem.

Tabela 16 Quantidade de animais (e \% por raça) por tratamento e por raça em atividade cíclica reprodutiva antes e após a introdução dos machos. 
Tabela 17 Classificação (grupos) de acordo com a atividade cíclica reprodutiva antes e depois da introdução dos machos.

Tabela 18 Resultado da análise de variância para o retorno da ACR, em ovelhas Santa Inês, Romney Marsh e Suffolk, considerando o fator tratamento (análise I) ou peso (análise II).

Tabela 19 Médias e desvio padrão de dias para retornar a ACR em ovelhas Santa Inês, Romney Marsh e Suffolk, por tratamento nutricional (análise I) e por ganho de peso (análise II).

Tabela 20 Médias e desvio padrão de dias para retornar a ACR de fêmeas Santa Inês e Suffolk......

Tabela 21 Resultados da análise de variância referente às concentrações plasmáticas de melatonina $(\mathrm{pg} / \mathrm{mL})$ de ovelhas das raças Santa Inês, Romney Marsh e Suffolk no período 1 (antes do início do tratamento nutricional em 22/09/2001).

Tabela 22 Resultados da análise de variância referente às concentrações plasmáticas de melatonina $(\mathrm{pg} / \mathrm{mL})$ de ovelhas das raças Santa Inês, Romney Marsh e Suffolk no período 2 (antes da introdução dos machos em 20/10/2001).

Tabela 23 Resultados da análise de variância referente às concentrações plasmáticas de melatonina $(\mathrm{pg} / \mathrm{mL})$ de ovelhas das raças Santa Inês, Romney Marsh e Suffolk no período 3 (final do período experimental em 01/12/2001).

Tabela 24 Resultados da análise de variância referente a duração da secreção de melatonina noturna (horas) observada em ovelhas Santa Inês, Romney Marsh e Suffolk no final do período experimental em 01/12/2001.

Tabela 25 Resultados da análise de variância referentes ao horário de início (análise I) e de término (análise II) da secreção de melatonina observada em ovelhas Santa Inês, Romney Marsk e Suffolk no final do período experimental em 01/12/2001. 


\section{LISTA DE FIGURAS}

Figura 1

Fêmeas da raça Santa Inês

Figura 2

Fêmeas da raça Romney Marsh.

Figura 3

Fêmeas da raça Suffolk.

Figura 4

Animais no pasto no período diurno.

Figura 5

Machos vasectomizados.

Figuras 6 e $7 \quad$ Mistura de tinta utilizada na região prepucial dos machos.

Figura 8

Fêmea da raça Santa Inês em estro, marcada pelo rufião.

Figura 9

Colheita de sangue de uma fêmea Santa Inês..

Figuras 10 e 11 Processamento do sangue e estocagem.

Figuras 12 e 13 Baia de colheita de sangue (com lona plástica para evitar a entrada de luzes externas)

Figura 14

Médias e desvio padrão do ganho de peso total $(\mathrm{kg})$ de fêmeas Santa Inês (SI), Romney Marsh (RM) e Suffolk (SU) de acordo com os tratamentos nutricionais, durante todo o período experimental.

Figura 15

Concentrações plasmáticas de progesterona (P4) por animal antes e após a introdução dos machos das fêmeas Santa Inês do grupo suplementado.

Figura 16 Concentrações plasmáticas de progesterona (P4) por animal antes e após a introdução dos machos das fêmeas Santa Inês do grupo não suplementado.

Figura 17 Concentrações plasmáticas de progesterona (P4) por animal antes e após a introdução dos machos das fêmeas Suffolk do grupo suplementado.

Figura 18 Concentrações plasmáticas de progesterona (P4) por animal antes e após a introdução dos machos das fêmeas Suffolk do grupo não suplementado.

Figura 19 Percentual de animais dentro de cada raça, de acordo com a classificação por grupos quanto a ACR.

Figura 20 Desdobramento por tratamento: percentual de animais de cada raça de acordo com a classificação por grupos quanto à ACR...

Figura 21

Desdobramento do fator tratamento (análise I - A) e do fator ganho de peso (análise II - B) dos dias para retornar a atividade cíclica reprodutiva (ACR) em ovelhas das raças Santa Inês, Romney Marsh e Suffolk......

Figura 22

Desdobramento do fator raça por tratamento (análise I - A) e ganho de peso (análise II - B) dos dias para retornar a atividade cíclica reprodutiva (ACR) em ovelhas das raças Santa Inês, Romney Marsh e Suffolk....... 
Figura 23 Médias e desvio padrão das concentrações plasmáticas de melatonina $(\mathrm{pg} / \mathrm{mL})$ no período $3(01 / 12 / 2001)$ de ovelhas das raças Santa Inês, Romney Marsh e Suffolk, de acordo com os tratamentos nutricionais (suplementadas e não suplementadas).

Figura 24 Concentrações plasmáticas médias de melatonina de ovelhas das raças Santa Inês, Romney Marsh e Suffolk, no período 3 (01/12/2001)

Figura 25 Médias das concentrações plasmáticas de melatonina $(\mathrm{pg} / \mathrm{mL})$ de ovelhas das raças Santa Inês, Romney Marsh e Suffolk, dentro de cada horário, por tratamento, no período $3(01 / 12 / 2001)$.

Figura 26 Médias das concentrações plasmáticas de melatonina de ovelhas Santa Inês, Romney Marsh e Suffolk por horário, no período 3 $(01 / 12 / 2001)$.

Figura $27 \quad$ Perfil das concentrações plasmáticas de melatonina das raças Santa Inês (A), Romney Marsh (B) e Suffolk (C), por tratamento, no período $3(01 / 12 / 2001)$

Figura 28 Médias e desvio padrão da duração da secreção noturna de melatonina (horas) em ovelhas das raças Santa Inês, Romney Marsh e Suffolk de acordo com os tratamentos de suplementação e não suplementação, no período $3(01 / 12 / 2001)$.

Figura 29 Início (horário) da secreção noturna de melatonina de ovelhas Santa Inês, Romney e Suffolk, de acordo com os tratamentos, no período 3 $(01 / 12 / 2001)$

Figura 30 Término (horário) da secreção noturna de melatonina de ovelhas Santa Inês, Romney e Suffolk, de acordo com os tratamentos, no período $3(01 / 12 / 2001)$.

Figura 31 Início (horário) da secreção noturna de melatonina de ovelhas das raças Santa Inês, Romney e Suffolk, no período 3 (01/12/2001).

Figura 32 Término (horário) da secreção noturna de melatonina de ovelhas das raças Santa Inês, Romney e Suffolk, no período $3(01 / 12 / 2001)$. 


\section{LISTA DE ABREVIATURAS}

$\mu \mathrm{L}$ - Microlitro

ACR - Atividade cíclica reprodutiva

$\mathrm{CP}$ - Crude Protein

EE - Extrato etéreo

ENN - Extrativo não nitrogenado

FB - Fibra bruta

FDA - Fibra em detergente ácido

FDN - Fibra em detergente neutro

FZEA - Faculdade de Zootecnia e Engenharia de Alimentos

GLM - General Linear Model

GnRH - Hormônio liberador de gonadotrofinas

ha - Hectare

LH - Hormônio luteinizante

MEL - Melatonina

$\mathrm{ML}$ - Mililitro

MM - Matéria mineral

MS - Matéria seca

NDT - Nutrientes digestíveis totais

$\mathrm{Ng}$ - Nanogramas

OPG - Ovos por grama

$\mathrm{P}_{4}$ - Progesterona

PB - Proteína bruta

$\mathrm{Pg}$ - Picogramas

PV - Peso vivo

RCA - Reproductive Cyclic Activity

RIE - Radioimunoensaio

RM - Romney Marsh

SAS - Statistical Analysis System

SI - Santa Inês

SU - Suffolk

TDN - Total Digestible Nutrients

UA - Unidade animal

UFSCAR - Universidade Federal de São Carlos

USP - Universidade de São Paulo 


\section{RESUMO}

O presente trabalho teve como objetivo avaliar os efeitos de diferentes condições nutricionais (suplementação e não suplementação) na atividade cíclica reprodutiva (ACR) em ovelhas das raças Santa Inês (SI), Romney Marsh (RM) e Suffolk (SU) mantidas sob pastejo, e submetidas ao efeito macho, durante época de anestro sazonal sob fotoperíodo natural no Estado de São Paulo. Avaliou-se também os efeitos destes tratamentos nas concentrações plasmáticas de melatonina (MEL) e na duração (horas) da secreção noturna deste hormônio. Todos animais foram mantidos sob pastejo, sendo que metade de cada raça recebeu suplementação e a outra não, caracterizando os tratamentos de suplementação e não suplementação, respectivamente. O tratamento de suplementação forneceu de 100 a $110 \%$ dos requerimentos protéicos (PB) e de 130 a $140 \%$ dos requerimentos energéticos (NDT), enquanto que o tratamento de não suplementação forneceu de 60 a $70 \%$ de PB e $100 \%$ de NDT. Os tratamentos nutricionais iniciaram 21 dias antes da introdução dos machos, e continuaram por todo o período de permanência dos mesmos (45 dias). Para o efeito macho, foram utilizados três machos (rufiões), impregnados com tinta na região prepucial para detecção do estro, os quais permaneceram isolados das fêmeas por um período de 60 dias. Colheitas de sangue foram realizadas antes (a cada 3 dias) e após (a cada 2 dias) a introdução dos machos, para dosagem de progesterona plasmática, a fim de monitorar a ACR das fêmeas. Foram também realizadas colheitas de sangue para dosagem de MEL plasmática: antes do início do experimento, antes da introdução dos machos e no final do experimento, em período de 24 horas, a cada 2 (noite) ou 4 (dia) horas. Os parâmetros avaliados foram: ganho de peso, ACR após introdução dos machos nos animais que se encontravam em anestro, dias para retorno da ACR, concentrações plasmáticas de MEL, duração da secreção de MEL. Estes parâmetros foram analisados utilizando o procedimento GLM no SAS, seguido pelo teste de ukey para estabelecer a comparação entre médias. O tratamento nutricional teve efeito no ganho de peso $(P<0,001)$, no número de dias para retorno da $\operatorname{ACR}(P<0,1)$, nas 
concentrações de MEL $(P<0,1)$ e na duração da secreção deste hormônio $(P<0,1)$. Animais suplementados apresentaram em média, maior ganho de peso, maiores concentrações de MEL plasmática, e maior duração da secreção deste hormônio. Diferenças raciais foram encontradas para ganho de peso, retorno da ACR e concentrações plasmáticas de MEL. Fêmeas SI, perderam peso, enquanto que as RM mantiveram e as SU ganharam peso durante todo o período experimental, independente do tratamento nutricional. Todas as fêmeas SI retornaram à ACR em média 5 dias após a introdução dos machos, já as fêmeas SU suplementadas não retornaram à $A C R$, enquanto que as não suplementadas retornaram em 23 dias. Nenhuma ovelha RM retornou à ACR. Assim, conclui-se que para a raça SI só efeito macho é eficiente em ativar o retorno da $A C R$, e para a raça $S U$, deve-se aliar esta prática com um bom manejo nutricional, e para a RM, o efeito macho mesmo associado à nutrição não são capazes de amenizar a estacionalidade da ACR. E por fim, a nutrição afeta a duração da secreção de MEL.

Palavras chave: Anestro, Efeito macho, Melatonina, Progesterona, Suplementação, Ovino. 


\section{ABSTRACT}

This study evaluated the effects of different nutritional conditions (suplementation and no suplementation) in reproductive cyclic activity (RCA) for Santa Inês (SI), Romney Marsh (RM) and Suffolk (SU) breeds, in pasture, submitted to the male effect, during seasonal anoestrus, under natural photoperiod in São Paulo State. It was also evaluated the effects of nutritional treatments for plasmatic melatonin (MEL) concentration and for the duration of MEL secretion. All ewes were mainted in pasture, receiving food supplementation or not, distinguishing the supplementation or not supplementation treatments. The supplementation treatment supplied 100$110 \%$ of protein requeriments (CP) and $130-140 \%$ of energy requeriments (TDN). The no supplementation treatment supplied $60-70 \%$ CP and 100\% TDN requeriments. The nutritional treatments were started 21 days before the rams introduction and lasted throughout the permanence period (45 days). To the male effect, it used three vasectomized rams impregnated with ink at the prepucial area in order to facilitate the estrus verification, isolated from the females for 60 days. Blood samples were collected before (every 3 days) and after (every 2 days) the rams introduction to determine de plasmatic progesterone to follow up the ewes reproductive cyclic activity (RCA). Blood samples were also collected to determine the plasmatic MEL dosage: before the beginning of the experiment, before the rams introduction and in the end of the experiment, during 24 hours, every 2 dark hours or 4 light hours. There was evaluated the following parameters: weight gain, RCA after male introduction for the ewes in anoestrus, days to RCA return, MEL concentration and MEL secretion duration. The parameters were analyzed by analisis of variance using the GLM (General Linear Procedure) of the Statistical System (SAS) software. Tukey test was used to compare means. The nutritional treatment resulted efficient for weight gain $(P<0,001)$, days to return $\operatorname{RCA}(P<0,1)$, MEL concentration $(P<0,1)$ and the duration of its hormone secretion $(P<0,1)$. Supplemented ewes showed higher weight gain, higher MEL plasmatic concentration and higher hormone secretion duration in average. There was verified breed differences for weight gain, RCA return and MEL plasmatic concentration. SI ewes lost weight in average, RM ewes maintained it and SU 
ewes gained weight during the whole experimental period not taking into account the nutritional treatment. SI ewes had, in average, their RCA returned 5 days after the rams introduction not taking into account the nutritional treatment. However, SU ewes presented different behaviours due treatments: the ones that received supplementation did not return the RCA while, the non supplemented ones returned the RCA within 23 days. RM ewes did not return RCA no matter which treatment had received. Therefore, one may conclude that for SI ewes the male effect is enough for the RCA return. For SU breed one should combine this practice to good nutritional management. And for RM neither the male effect nor the nutrition are capable to diminish the RCA seasonally. Finally, one may conclude that the nutrition affects the amount and duration of MEL secretion.

Key words: Anoestrus, Male effect, Melatonin, Progesterone, Supplementation, Ovine 


\section{INTRODUÇÃO}

A ovinocultura de corte no Estado de São Paulo é uma atividade que vem crescendo muito nos últimos anos principalmente devido a grande procura pela carne ovina (FERNANDES, 1999). Entretanto, o sucesso dessa atividade é determinado, entre outros fatores, pela taxa de produção de cordeiros para abate, que varia em função do número de matrizes e seu subsequente desempenho reprodutivo. A reprodução na ovelha também é afetada por vários fatores, dentre eles a estacionalidade reprodutiva e o estado nutricional (DYRMUNDSSON, 1973).

A estacionalidade reprodutiva afeta indiretamente a economicidade da ovinocultura de corte por restringir a produção de cordeiros para abate a um ciclo anual. Em geral, a maioria das raças de ovinos apresenta um modelo de reprodução sazonal com uma incidência de ciclos estrais concentrada durante o outono e inverno (HAFEZ, 1952; McDONALD, 1989; COELHO et al., 2000; SASA et al., 2000; SASA et al., 2001a). Apesar do fotoperíodo ser o principal fator externo que dirige tal estacionalidade, o ciclo de reprodução sazonal da ovelha não é controlado diretamente pelo fotoperíodo, ou seja, esse ciclo é controlado por um ritmo circanual endógeno o qual é sincronizado pelo fotoperíodo (MALPAUX et al., 1989). 
Os efeitos do fotoperíodo no controle hormonal da estacionalidade reprodutiva são mediados pela melatonina que, produzida pela glândula pineal, transforma a mensagem fotoperiódica em mensagem química (AREND et al., 1987; ENGLISH et al., 1988; ARENDT, 1995). A secreção de melatonina é limitada à fase escura do dia (escotoperíodo) e, na ovelha, a sua duração de secreção corresponde ao comprimento da noite (ARENDT, 1995). A modificação do padrão secretório da melatonina em respostas às mudanças do comprimento do dia transmite a informação fotoperiódica ao eixo hipotalâmicopituitário-gonadal e regiões do hipotálamo parecem ser o local alvo dos efeitos sazonais da melatonina (ARENDT, 1995; VIGUIÉ et al., 1997; MALPAUX et al., 1997) por modificar a secreção pulsátil do hormônio liberador de LH (LHRH) (MALPAUX et al., 1997).

Dentre as maneiras utilizadas para contornar ou amenizar a estacionalidade reprodutiva vale ressaltar a importância dos tratamentos hormonais (OLDHAM e PEARCE, 1984; HANRAHAN e O'RIORDAN, 1990; RODRIGUEZ-IGLESIAS et al., 1992; UMBERGER et al., 1994) e do efeito macho (MIES FILHO, 1975; MORAES, 1991; OTTO et al, 1998). O efeito macho, prática que consiste basicamente no condicionamento das fêmeas a um período de isolamento dos machos, seguido da introdução dos mesmos, está relacionado à sincronização de estros com ovulação em ovelhas, à concentração de partos em borregas e ovelhas submetidas à monta durante $\mathrm{o}$ anestro estacional (MORAES, 1991; OTTO et al, 1998), e à antecipação e sincronização da manifestação da puberdade (DYRMUNDSSON e LEES, 1972).

Uma outra forma de incrementar a reprodução das fêmeas ovinas é mediante o uso do manejo nutricional conhecido como "flushing" (GUNN et al., 
1991; KOTT, 2001), que consiste no aumento de energia oferecida aos animais, antes e durante a estação reprodutiva (NEARY, 2001). Entretanto, existem poucas informações sobre a suplementação alimentar prévia de ovelhas submetidas ao efeito macho durante o anestro sazonal.

Desta forma, o objetivo foi verificar o efeito do manejo alimentar no ganho de peso e no retorno da atividade cíclica reprodutiva em fêmeas ovinas mantidas em pastagem e submetidas ao efeito macho durante o anestro sazonal. E também verificar as conseqüências destes tratamentos nas concentrações plasmáticas de melatonina. Assim, o presente trabalho vislumbra as seguintes hipóteses: a) fêmeas mantidas a pasto, durante 0 anestro sazonal, quando submetidas a um manejo nutricional suplementar, podem antecipar o retorno da atividade cíclica reprodutiva mediante a utilização do efeito macho; b) fêmeas com diferentes condições nutricionais podem modificar o perfil plasmático da secreção de melatonina. 


\section{REVISÃO DE LITERATURA}

\subsection{Fotoperíodo e Reprodução}

A ovelha, quanto à reprodução, é classificada como um animal poliéstrico estacional, ou seja, apresenta um modelo de reprodução sazonal com uma incidência de ciclos estrais concentrada durante o outono e inverno (HAFEZ, 1952; McDONALD, 1989; COELHO et al., 2001; SASA et al., 2001a; SASA et al., 2002). Porém, esta característica é típica de raças originárias de climas frios e temperados (raças lanadas), enquanto que em raças de regiões tropicais e subtropicais (raças deslanadas), as fêmeas apresentam atividade cíclica reprodutiva ao longo do ano (ABOUL-NAGA et al., 1987; COELHO, 2001; SASA et al., 2001b).

Um dos principais fatores responsáveis pela estacionalidade reprodutiva em ovelhas é o fotoperíodo. Os ovinos oriundos de climas frios e temperados utilizam o ciclo anual do fotoperíodo (horas luz/dia) para determinar mudanças sazonais na atividade sexual. Estes animais apresentam uma estação reprodutiva bem definida durante o ano, a qual se estende desde o final do verão até início do inverno. Em ambos os hemisférios, essa espécie inicia a estação reprodutiva a medida que a luminosidade diária diminui, obedecendo o fotoperíodo decrescente (PINEDA, 1989), sendo classificados como animais de dias curtos. 
A resposta da atividade sexual ao fotoperíodo é também dependente da latitude. Em latitudes mais elevadas a estacionalidade reprodutiva está intimamente relacionada com o fotoperíodo, enquanto que em baixas latitudes esta relação é menos pronunciada (HAFEZ, 1952). Em regiões tropicais, próximas a linha do Equador, onde não existe variação da luminosidade diária, existe uma tendência das raças nativas apresentarem-se como poliéstricas não estacionais, ou seja, os ciclos estrais ocorrem ao longo do ano (FIGUEIREDO et al., 1980; McDONALD, 1989, GALINA et al., 1996). Nesse caso, a estacionalidade reprodutiva está condicionada a outros fatores mais importantes do que o fotoperíodo, tais como a temperatura, a raça e a nutrição (SIMPLíCIO et al., 1982; SILVA e NUNES, 1987; SILVA et al., 1987).

No Brasil, cuja área geográfica se estende tanto sobre a linha do Equador (Regiões Nordeste e Norte) como sobre uma grande variação de latitudes ao Sul (Região Central, Sudeste e Sul), a duração da estação reprodutiva das ovelhas varia consideravelmente. Na Região Nordeste, as ovelhas deslanadas ciclam ao longo do ano, podendo ser acasaladas mais de uma vez ao ano (FIGUEIREDO et al., 1980; GIRÃO et al., 1984). Nessa região a estacionalidade da atividade reprodutiva varia mais em função da temperatura e da nutrição (SIMPLíCIO et al., 1982; SILVA e NUNES, 1987; SILVA et al., 1987). Na Região Sul, vários trabalhados realizados com raças de duplo propósito e especializadas para produção de carne apresentaram uma estação reprodutiva mais restrita a estação de outono (NUNES e FIGUEIRÓ, 1975; SILVA e FIGUEIRÓ, 1980; RIBEIRO et al., 1996). Já na região Sudeste, é possível observar uma certa estacionalidade na atividade reprodutiva nas ovelhas lanadas (PRUCOLLI e BACCARI Jr., 1967; RODA et al., 1993; 
COELHO et al., 2000a, COELHO et al., 2000b, SASA et al., 2000; SASA et al., 2001). Em contrapartida, nessa região as raças deslanadas não apresentaram estacionalidade da atividade reprodutiva (TRALDI, 1990; COELHO et al., 2000a, COELHO et al., 2000b).

Indubitavelmente, o fotoperíodo é o fator de maior importância na determinação da estacionalidade reprodutiva dos ovinos (MALPAUX et al., 1997). De acordo com a literatura revista por LINCOLN (1992), os animais que regulam atividade reprodutiva através do fotoperíodo têm um sistema de mensuração do tempo fotoperiódico que codifica as horas luz/dia em sinal hormonal, o qual atua no sistema nervoso central (SNC), para coordenar mudanças sazonais reprodutivas. O SNC funciona como relógio biológico interno que, através dos neurônios, regula o ritmo circadiano endógeno e, a glândula pineal - através de sua ligação com o SNC por inervação simpática funciona como transdutor, convertendo a informação neural dependente do ciclo noite-dia (24 h) em sinal hormonal pela variação do tempo de secreção de melatonina. A melatonina, secretada pela glândula pineal, é liberada na circulação periférica somente a noite e a duração dessa secreção determina um perfil endócrino de comprimento noturno, consequentemente, das horas de luz diária (fotoperíodo) sendo um fator crítico na transferência da informação fotoperiódica que induz a atividade reprodutiva (ENGLISH et al., 1988). Desse modo, a atividade reprodutiva estacional é gerada por um ciclo anual endógeno que não é dirigido, mas sim, causado pelo fotoperíodo. E a alternância de claro-escuro é o mais importante fator para os ritmos circadianos (ARENDT, 1995). 
Na região Sudeste do Brasil, RODRIGUES (2001) e COELHO et al. (2002), estudando o perfil de concentrações plasmáticas de melatonina e a estação reprodutiva ao longo do ano, verificaram que ovelhas lanadas Suffolk e Romney Marsh possuem uma estacionalidade reprodutiva, e a glândula pineal, através da secreção de melatonina parece regular esta atividade, enquanto que fêmeas da raça deslanada Santa Inês não apresentaram estacionalidade reprodutiva, embora o perfil de secreção de melatonina tenha sido o mesmo das raças lanadas. Esses resultados indicam que, nesta raça, a glândula pineal não interfere de modo significativo a atividade do eixo hipotálamo-hipófisegonadal, sendo talvez o fator genético mais preponderante.

\subsection{Ciclo estral em ovelhas}

O comprimento do ciclo estral em ovelhas é descrito pela literatura, em média, de 17 dias. Porém, a definição mais utilizada da duração do ciclo estral foi descrita por HAFEZ (1952), que classificou essa duração em ciclos simples (até 26 dias) e múltiplos (27 - 57 dias). Os ciclos estrais simples foram divididos em ciclos curtos (< 14 dias), normais (14 - 19 dias) e longos (20-26 dias), enquanto que os múltiplos em duplos (27 - 37 dias) e triplos (38 - 57 dias). Esse autor e outros (DYRMUNDSSON \& LEES, 1972; QUIRKE, 1978; BATHAEI, 1996), posteriormente, assumiram que ovulações sem comportamento de estro (silenciosas) ocorreram entre dois períodos de estros clínicos em ciclos estrais maiores que 26 dias. As presenças de tais ovulações foram confirmadas por HARE \& BRYANT (1982) mediante a determinação das concentrações plasmáticas de progesterona. Porém, a curta duração do estro e a baixa intensidade de sua manifestação (HAFEZ, 1952; DYRMUNDSSON, 
1978) bem como a presença de ovulações silenciosas (HARE \& BRYANT, 1982; ABECIA et al., 1996) e de ciclos estrais irregulares ou longos (HAFEZ, 1952; BATHAEI, 1996, COELHO et al, 2000a) são mais comuns em borregas em início de idade reprodutiva ou em início e final da estação reprodutiva.

PINEDA (1989) descreveu as fases do ciclo estral, sendo como, folicular e lútea. A fase folicular dura cerca de dois a três dias, e é o período em que os folículos crescem e produzem o ovócito, sendo caracterizada pelo comportamento de estro, pico de LH pré-ovulatório e o surgimento da ovulação. A fase lútea é caracterizada pela presença de um ou mais corpos lúteos. $O$ comprimento da fase lútea determina o comprimento do ciclo.

Segundo HEAPE (1990), uma outra forma de dividir o ciclo estral seria a classificação em proestro, estro, metaestro e diestro.

O proestro tem duração de dois a três dias e é caracterizado pelo crescimento folicular e secreção de estrógeno, sob estímulo de gonadotrofinas hipofisárias. As concentrações de estrógeno aumentam progressivamente no sangue, e estão associadas com alterações nos órgãos reprodutivos, como aumento no suprimento sangüíneo no trato genital (JAINUDEEN \& HAFEZ, 1993). As ovelhas não apresentam sinais evidentes durante o proestro, entretanto com a aproximação do estro, a vulva torna-se edemaciada, o vestíbulo torna-se hiperêmico e as glândulas da cérviz e vagina produzem secreção serosa que aparece como um corrimento vaginal (PINEDA, 1989).

O estro varia de 20 a 36 horas, com média de 26 horas (PINEDA, 1989, LINDSAY, 1991; JAINUDEEN \& HAFEZ, 1993). A ovulação é espontânea e ocorre no final do estro, cerca de 24-27 horas após o seu início (ROBINSON, 1959). Ovulações duplas e triplas são comuns, e estas ocorrem dentro de duas 
horas após a primeira ovulação (LINDSAY, 1991). LAMMING \& MANN (1995) descreveram que o estímulo hormonal para o estro é o estradiol, mas um período de exposição a progesterona, de 6-8 dias é essencial para que a fêmea seja sensível ao estrógeno. Seguido vinte e quatro horas do pico de LH, ocorre a ovulação. Estes autores relacionaram a ocorrência de ovulações silenciosas no início da estação reprodutiva em ovelhas adultas e no início da puberdade, com a falta de progesterona. Assim, enfatizaram que a progesterona é necessária para a expressão do comportamento estral e é fornecida pelo corpo lúteo formado na primeira ovulação silenciosa.

O metaestro é definido como o período de formação do corpo lúteo, e para fins práticos, é incluído no diestro (PINEDA, 1989). O diestro (fase lútea), fase dominante no ciclo estral da ovelha, dura 12 a 14 dias e é caracterizada pela secreção de progesterona pelo corpo lúteo. Embriões viáveis devem estar presentes no útero até o dia 13 do diestro para fornecer sinal luteotrópico (PINEDA, 1989). Se não há embriões viáveis presentes, o corpo lúteo regride rapidamente sob a influência da $\mathrm{PGF}_{2 \alpha}$ (secretada pelo útero), reduzindo a quantidade de progesterona circulante, permitindo a ovelha iniciar outro ciclo estral (ZARCO et al., 1988). Este processo repete-se durante subseqüentes ciclos até o final da estação reprodutiva, se a ovelha não se tornar prenhe.

De acordo com MINTON et al. (1990), valores plasmáticos de progesterona inferiores a $1 \mathrm{ng} / \mathrm{mL}$ podem caracterizar as fases de estro ou de anestro, enquanto valores superiores a $3 \mathrm{ng} / \mathrm{mL}$ caracterizam a fase de diestro (luteal) ou gestação. A fase de anestro diferencia-se da fase de estro quando as concentrações de progesterona permanecem baixas por um período superior a dez dias. COELHO et al. (2000b), trabalhando com os mesmos animais do 
estudo em questão, verificaram que as médias de concentrações plasmáticas de progesterona durante as fases do ciclo estral das fêmeas Santa Inês, Romney Marsh e Suffolk foram de 0,$45 ; 0,30$ e $0,39 \mathrm{ng} / \mathrm{mL}$ no estro, 1,$64 ; 1,91$ e 1,88 $\mathrm{ng} / \mathrm{mL}$ no metaestro, 4,$30 ; 4,86$ e $4,33 \mathrm{ng} / \mathrm{mL}$ no diestro e 2,$16 ; 2,33$ e 1,47 $\mathrm{ng} / \mathrm{mL}$ no proestro.

\subsection{Estação reprodutiva e anestro}

A ação da melatonina no controle da função reprodutiva ocorre através da modulação da secreção de LH, em que alterações nos seus níveis e freqüência de pulsos caracterizam a estação reprodutiva e não-reprodutiva (KARSH et al., 1984). Assim, a estação reprodutiva em ovelhas é caracterizada pela capacidade da fêmea regular a secreção pulsátil de $L H$, na freqüência e amplitude apropriadas das fases, folicular e lútea, do ciclo estral. A freqüência de pulsos de LH controla a secreção de estradiol, necessário para disparar o pico pré-ovulatório de LH. Na estação não-reprodutiva o mecanismo gerador de pulsos de LH torna-se extremamente sensível ao estradiol, assim, quantidades limitadas deste hormônio produzidos pelos folículos no anestro é suficiente para manter freqüências muito baixas de pulsos de LH. Durante a estação reprodutiva este sistema gerador permanece insensível ao estradiol, aumentando a freqüência e a liberação de tônica de LH. Desta forma, a resposta a sensibilidade ao estradiol é baixa durante a estação reprodutiva, aumenta durante a transição para o anestro e permanece alta durante todo o período não-reprodutivo.

A percepção de dias curtos após dias longos pelos animais é o sinal para reduzir a sensibilidade do gerador de pulso ao efeito inibitório do estradiol, 
o que ocorre a partir do solstício de verão (THIMONIER e MAULÉON, 1969). Ao contrário, dias longos após dias curtos restauram a sensibilidade e inibem a atividade reprodutiva. Desta forma, basicamente, a diferença da estação reprodutiva e do período de anestro é causado pela não capacidade de promover o aumento (pico) de LH, e todo o resto é conseqüência deste fato.

\subsection{Alternativas para amenizar a estacionalidade reprodutiva}

\subsubsection{Efeito macho}

O efeito macho é uma prática que consiste no condicionamento das fêmeas a um período mínimo de 30 dias de isolamento visual, olfativo e auditivo dos machos, seguido da introdução dos mesmos (THIMONIER et al., 2000). O emprego do efeito macho na fisiologia reprodutiva está relacionado à sincronização de estros com ovulação em ovelhas durante anestro estacional (MIES FILHO, 1975), à concentração de partos em borregas e ovelhas submetidas à monta durante o anestro estacional (MORAES, 1991; OTTO et al, 1998), à antecipação e sincronização da manifestação da puberdade (DYRMUNDSSON e LEES, 1972) e também a possibilidade da redução da duração do estro (LINDSAY e SIGNORET, 1980).

A presença do macho, após o período de isolamento, causa um aumento nos níveis plasmáticos de LH e/ou maior sensibilidade aos estrógenos dentro de um período de 20-40 horas (MORAES, 1991). A ovulação normalmente ocorre nas próximas 24 horas (MARTIN et al., 1986).

O efeito macho apresenta melhores resultados quando utilizado cerca de seis semanas antes do início da estação reprodutiva de acordo com cada raça, 
pois caso contrário, quando utilizado muito antes do início da estação reprodutiva, as fêmeas podem apenas ovular sem manifestar o estro e posteriormente retornar à condição de anestro (LINDSAY e SIGNORET, 1980). As condições nutricionais (HULET et al., 1986) e raça (NUGENT III et al., 1988) também podem interferir no percentual de ovelhas em anestro que respondem ao efeito macho. A proporção de ovelhas que respondem ao efeito macho no anestro sazonal, é dependente ainda, do feromônio e comportamento sexual emitido pelo macho (WATSON e RADFORD, 1960). E estas características dos machos são melhoradas quando estes são expostos à fêmeas em estro antes da introdução no grupo de fêmeas em anestro, pois de acordo com vários trabalhos (SANFORD et al., 1974; GONZALEZ et al., 1991; PERKINS et al., 1992) a exposição do macho ao estro de ovelhas aumenta os níveis de $\mathrm{LH}$ e conseqüentemente a secreção de testosterona, influenciando positivamente na produção de feromônios (HAYNES e HARESIGN, 1987).

Vários trabalhos (PEARCE e OLDHAM, 1984; MARTIN et al, 1986) têm indicado que até o terceiro dia após a introdução dos machos, as fêmeas ovulam, sendo que a partir desse momento, ou passam a ciclar normalmente ou apresentam um ciclo curto intermediário, em decorrência da deficiência de progesterona, já que essas fêmeas anteriormente apresentavam ovários afuncionais (LEGAN et al., 1985). E o estro mais fértil após a introdução do macho, é descrito como sendo o segundo (OTTO et al., 1998).

A técnica do efeito macho é uma técnica barata, que tem mostrado bons resultados por si só, porém vem sendo muito utilizada em associação com outras técnicas como a nutrição e tratamentos hormonais. 


\subsubsection{Tratamentos hormonais}

Os tratamentos hormonais existentes para induzir o estro e a ovulação, durante o anestro sazonal das ovelhas, consistem basicamente, na tentativa de mimetizar a fase luteal do ciclo estral (produção de progesterona) mediante a colocação de implantes que, ao serem retirados, provocam a queda dos níveis de $\mathrm{P}_{4}$ e conseqüentemente o estro e a ovulação (GORDON, 1997). Desta forma, tratamentos com progestágenos são comumente utilizados em associação ao efeito macho (COGNIE et al., 1982; OLDHAM e PEARCE, 1984; HANRAHAN e O'RIORDAN, 1990; RODRIGUEZ-IGLESIAS et al., 1992; AKSOY et al., 1994; UMBERGER et al., 1994) obtendo resultados satisfatórios.

De outra forma, a utilização de melatonina exógena tem como objetivo "enganar" o animal quanto ao fotoperíodo, dando-lhe a impressão de dias curtos, antecipando o retorno da atividade reprodutiva. Inúmeros são os trabalhos (ARENDT et al., 1983; ENGLISH et al., 1986; WALLACE et al., 1988; GUERIN et al. 1989; DUROTOYE et al., 1991; FORCADA et al., 1995) que têm demonstrado que a melatonina administrada diariamente por injeção, via oral ou através de implantes, é eficaz em induzir ou antecipar a atividade cíclica reprodutiva de ovelhas, em época de anestro sazonal, sem (REKIK et al., 1991) ou com (GÓMEZ BRUNET et al., 1995) auxílio do efeito macho. Alguns estudos demonstraram ainda que os implantes de melatonina, além de aumentar as concentrações plasmáticas de melatonina dos animais tratados em relação aos animais controles (NOWAK et al., 1990) podem promover um aumento da taxa de ovulação e conseqüente incremento da prolificidade (DUROTOYE et al., 1991: REKIK et al., 1991; GÓMEZ BRUNET et al., 1995; LALIOTIS et al., 1997), principalmente em condições de baixo escore corporal 
(ROBINSON et al., 1991; RONDON et al., 1996). Porém, outros trabalhos também evidenciam a falta de resposta em animais que tiveram uma mudança drástica de fotoperíodo antes do tratamento (ELDON, 1993), ou a diminuição de resposta e/ou diminuição da taxa de ovulação após prolongados períodos de exposição aos tratamentos de melatonina (JORDAN et al., 1990).

\subsection{Nutrição e reprodução}

Relações entre nutrição e reprodução nos animais domésticos têm sido bastante estudada. $\mathrm{O}$ impacto da nutrição na atividade reprodutiva é causada por efeitos diretos e indiretos nos tecidos reprodutivos. Em ovelhas, a técnica conhecida como "flushing" (maior fornecimento de energia na dieta de duas a três semanas antes e durante a estação de monta) tem como objetivo aumentar a taxa de ovulação e melhorar a fertilidade (GUNN et al., 1991; KOTT, 2001; NEARY, 2001). Porém, os mecanismos exatos de como a nutrição afeta a reprodução não está bem esclarecido. Sabe-se que a quantidade de gordura corporal (condição corporal) afeta a atividade hipotalâmica e a secreção de $\mathrm{GnRH}$, afetando a performance reprodutiva (GORDON, 1997).

A técnica de "flushing" ou uma dieta mais rica nutricionalmente é muito utilizada com o objetivo de aumentar a taxa de ovulação, sendo fornecida em média 30 dias antes do início da estação reprodutiva. Esta técnica também é utilizada em associação com outras técnicas para diminuir a duração do anestro sazonal, antecipando o início da estação reprodutiva (KOTT, 2001).

Um efeito positivo da nutrição na resposta de tratamentos de melatonina tem sido observado (ROBINSON et al., 1991). Já em outros trabalhos (FORCADA et al., 1995; RONDÓN et al., 1996), em ovelhas mediterrâneas 
com implantes de melatonina, um aumento na taxa de ovulação e antecipação da estação reprodutiva tem ocorrido em animais subalimentados e/ou com baixo escore de condição corporal, comparados à animais superalimentados e/ou com alto escore de condição corporal. Estas discrepâncias de resultados se deve a diferenças na condição de escore corporal. Melhores resultados reprodutivos através do manejo nutricional são obtidos quando o animal apresenta uma condição corporal mediana ou baixa. Em animais de baixa condição corporal, a nutrição não é capaz de incrementar a eficiência reprodutiva. (SUSIN, 1996). E em animais de alta condição corporal (excesso de gordura corporal) uma restrição nutricional pode afetar positivamente a atividade reprodutiva. 


\section{MATERIAL E MÉTODOS}

\subsection{Local e Período de Realização do Experimento}

O experimento foi realizado durante o período de setembro a novembro de 2001, no Departamento de Ciências Básicas da Faculdade de Zootecnia e Engenharia de Alimentos (FZEA) da Universidade de São Paulo (USP), Campus de Pirassununga-SP. O local está situado na latitude $21^{\circ} 59^{\prime}$ sul, na longitude $47^{\circ} 25^{\prime}$ oeste e a $634 \mathrm{~m}$ de altitude. O clima é classificado como subtropical Cwa Koppen, e o solo como Latossolo Vermelho Escuro Orto. A precipitação pluviométrica anual é de $1300 \mathrm{~mm}$ e a temperatura média de $21^{\circ} \mathrm{C}$, sendo a mínima de $13^{\circ} \mathrm{C}$ e a máxima de $35^{\circ} \mathrm{C}$.

\subsection{Animais e Manejo}

Foram utilizados trinta e seis fêmeas ovinas, em atividade sexual, com idades variando de 39 a 49 meses, sendo dez da raça Santa Inês (figura 1), onze Romney Marsh (figura 2) e quinze Suffolk (figura 3). Todos animais foram pesados, vacinados ${ }^{1}$ e desverminados ${ }^{2}$ antes do início do experimento. As fêmeas permaneceram sob pastejo (Panicum maximum cv. Aruana) durante o

\footnotetext{
${ }^{1}$ Sintoxan Polivalente (Rhodia)

${ }^{2}$ Ivomec
} 
dia (figura 4), e confinadas no período noturno em condições de fotoperíodo natural. No final da tarde, quando confinadas, metade dos animais receberam uma suplementação concentrada ${ }^{3}$ (300g/cabeça/dia). Todos os animais receberam sal mineral ${ }^{4}$ e água à vontade e apresentavam condição de escore corporal médio no início do experimento.

Periodicamente os animais foram submetidos a pesagem para determinação do ganho de peso, e à coleta de fezes para contagem de ovos por grama (OPG) para monitoração da infestação parasitária.

\subsection{Tratamentos nutricionais}

As fêmeas foram divididas em dois grupos: o primeiro foi suplementado com concentrado comercial (tratamento 1), e outro grupo, não (tratamento 2). O fornecimento diário do concentrado (250 a 300 g/cabeça) iniciou-se 21 dias antes do início da introdução dos machos e se estendeu até o final da permanência (45 dias) dos mesmos. O concentrado (tabela 1) era fornecido em cochos coletivos, com espaço suficiente para o acesso de todos os animais. No início e meio do período experimental, para maior controle do plano nutricional, foram realizadas amostragens (simulação de pastejo, a $5 \mathrm{~cm}$ do solo) do pasto para análise bromatológica (tabela 2).

O tratamento 1 (suplementação) forneceu de 100 a $110 \%$ dos requerimentos das necessidades protéicas (PB) e de 130 a 140\% dos requerimentos energéticos (NDT), enquanto que o tratamento 2 forneceu de 60 a $70 \%$ de PB e $100 \%$ da de NDT (NRC, 1985).

\footnotetext{
${ }^{3}$ Tech Ovin Unique (Socil)

${ }^{4}$ Guyo Sal mineral para ovinos (Socil)
} 
Tabela 1. Valores bromatológicos do concentrado comercial utilizado no tratamento 1 (suplementação).

\begin{tabular}{lc}
\hline \multicolumn{1}{c}{ Parâmetro } & Valor em $100 \%$ de MS (\%) \\
\hline PB & 19,00 \\
FB & 11,00 \\
FDA & 16,00 \\
FDN & 26,00 \\
EE & 2,20 \\
Minerais (Ca e P) & 1,75 \\
ENN & 66,05 \\
NDT estimado & 71,69 \\
\hline \multicolumn{2}{c}{ PB (proteína bruta), FB (fibra bruta), FDN (fibra em detergente neutro), FDA (fibra em } \\
\multicolumn{2}{c}{ detergente ácido), EE (extrato etéreo), ENN (extrativo não nitrogenado), NDT } \\
$\quad$ (nutrientes digestiveis totais) estimado.
\end{tabular}

Tabela 2. Análise bromatológica do capim Panicum maximum cv. Aruana no início e meio do período experimental.

\begin{tabular}{lcc}
\hline \multicolumn{1}{c}{ Parâmetro } & Início (25/09/2001) & Meio (30/10/2001) \\
\hline MS (\%) & 36,90 & 32,73 \\
MM (\%) * & 8,85 & 7,13 \\
FB (\%) * & 31,30 & 34,36 \\
FDN (\%) * & 78,16 & 81,60 \\
FDA (\%) * & 43,79 & 46,28 \\
EE (\%) * & 1,04 & 0,75 \\
PB (\%) * & 5,47 & 5,15 \\
ENN (\%) * & 53,34 & 52,61 \\
NDT estimado (\%) * & 56,98 & 56,85 \\
MS disponível (Kg/ha) & 1955,93 & 1721,63 \\
\hline \multicolumn{2}{c}{${ }^{*}$ Resultados em 100\% de MS } \\
\multicolumn{2}{c}{ MS (matéria seca), MM (matéria mineral), FB (fibra bruta), FDN (fibra em detergente } \\
neutro), FDA (fibra em detergente ácido), EE (extrato etéreo), PB (proteína bruta), ENN \\
(extrativo não nitrogenado), NDT (nutrientes digestíveis totais) estimado.
\end{tabular}




\subsection{Efeito macho}

As fêmeas permaneceram um mínimo de 60 dias isoladas da presença (visual e olfativa) dos machos até a introdução de três machos vasectomizados (figura 5). A permanência dos machos no grupo de fêmeas teve a duração de 45 dias e ocorreu em época de anestro sazonal (outubro e novembro).

\subsection{Detecção do estro}

Os machos foram impregnados com uma mistura de tinta em pó e óleo comestível na região prepucial (figuras 6 e 7) para verificar as fêmeas em estro. O grupo das fêmeas era observado diariamente (duas vezes ao dia, pela manhã e final da tarde) e as fêmeas que apresentaram a região dorsal ou próxima a vulva marcada ou aquelas que se deixaram montar pelo macho eram consideradas em estro (figura 8). Para facilitar a identificação, a cor da tinta era trocada a cada 10 dias, seguindo a ordem: amarelo, verde, azul e vermelha.

Esta prática de detecção do estro foi confrontada e confirmada com as dosagens plasmáticas de progesterona.

\subsection{Colheita de sangue para determinação das concentrações plasmáticas de progesterona $\left(\mathrm{P}_{4}\right)$ e melatonina (MEL)}

Para determinação das dosagens hormonais, amostras de sangue foram colhidas da veia jugular dos animais (figura 9), utilizando agulhas descartáveis $21 \mathrm{G}$ acopladas em tubos a vácuo heparinizados com volume de $10 \mathrm{~mL}$. Todas as amostras de sangue foram centrifugadas por quinze minutos a $1600 \mathrm{~g}$ e os plasmas estocados a $-20^{\circ} \mathrm{C}$ até o momento das análises (figuras 10 e 11). 
Para determinação das concentrações plasmáticas de progesterona, amostras de sangue foram colhidas em duas épocas de todas as fêmeas: antes do início do tratamento nutricional (a cada três dias durante 20 dias) e durante a estação de monta (a cada dois dias durante 45 dias), a fim de monitorar a atividade cíclica reprodutiva de cada fêmea.

Para determinação das concentrações plasmáticas de melatonina, amostras de sangue foram colhidas da metade de cada grupo (totalizando 18 animais) em três épocas: antes do início do fornecimento da suplementação (Período 1), antes (Período 2) e após (Período 3) a estação de monta. Cada colheita foi realizada num período de 24 horas, a cada 4 horas durante 0 período de luz (8:00, 10:00 e 16:00 horas) e a cada 2 horas no período escuro $(18: 00,20: 00,22: 00,0: 00,2: 00,4: 00$ e 6:00 horas). A colheita de sangue foi

realizada em baia (figuras 12 e 13) envolvida com lona plástica com a finalidade de evitar que, durante o período noturno, os animais não observassem as luzes artificiais (luzes da cidade, dos prédios, dos postes), próximos ao local da colheita. Este procedimento não escureceu artificialmente a instalação. Durante a colheita noturna, foi utilizada como fonte de luz uma lanterna adaptada com filtro de luz vermelha $(25 \mathrm{~A}) 58 \mathrm{M}^{3}$ e jamais direcionada aos olhos dos animais.

\subsection{Determinação das concentrações plasmáticas de $\mathbf{P}_{4}$}

As dosagens hormonais de progesterona foram executadas no Labaratório de Neuroendocrinologia do Departamento de Ciências Fisiológicas da Universidade Federal Federal de São Carlos (UFSCAR). 
As concentrações plasmáticas de progesterona foram determinadas pelo método de radioimunoensaio (RIE) em fase sólida, utilizando-se conjuntos de reagentes comerciais $^{5}$, desenvolvidos para avaliação quantitativa deste hormônio, sem qualquer tipo de extração química e processo de purificação, valendo-se do iodo ${ }^{125}$ como elemento radioativo traçador. Os procedimentos utilizados foram aqueles especificados pelo fabricante.

As contagens de radioatividade foram obtidas pela utilização de contador gama (LKB, modelo 1275) calibrado automaticamente para I ${ }^{125}$. Os resultados foram fornecidos pelo uso do programa específico de computador.

A dosagem de progesterona foi realizada em dois ensaios, e os parâmetros de qualidade do mesmo encontram-se na tabela 3. O limite de detecção do ensaio foi $0,02 \mathrm{ng} / \mathrm{mL}$, determinado pelo fabricante dos kits, e o coeficiente de variação interensaio de 2,51\%.

Tabela 3. Coeficientes de variação intra-ensaio dos ensaios hormonais (RIE) para a progesterona.

\begin{tabular}{cc}
\hline Ensaio & C.V. intra-ensaio (\%) \\
\hline 1 & 2,01 \\
2 & 1,27 \\
\hline
\end{tabular}

\footnotetext{
${ }^{5}$ COAT-A-COUNT - Diagnostic Products Company, Los Angeles, CA, USA
} 


\subsection{Determinação das concentrações plasmáticas de melatonina}

As dosagens hormonais de melatonina foram executadas no Labaratório de Neuroendocrinologia do Departamento de Ciências Fisiológicas da Universidade Federal de São Carlos (UFSCAR).

A determinação dos níveis plasmáticos de melatonina foi realizada utilizando-se a técnica de radioimuensaio (RIE) descrita por FRAZER et al. (1983) e modificada por STOKKAN et al. (1991). As curvas padrão foram obtidas por meio de diluição de melatonina ${ }^{6}$ variando de 2 a $1000 \mathrm{pg} / \mathrm{mL}$. O ensaio foi realizado incubando $250 \mu \mathrm{L}$ de padrão ou plasma das amostras, 100 $\mu \mathrm{L}$ de anticorpo anti-melatonina ${ }^{7}$, diluição final de 1:15000, $100 \mu \mathrm{L}$ de melatonina tritiada ${ }^{8}$ (aproximadamente $3000 \mathrm{cpm}$ ) e $50 \mu \mathrm{L}$ de tampão tricina. Todas as diluições foram realizadas com solução tampão de tricina (tricina $0,1 \mathrm{M}$, gelatina $0,1 \%, \mathrm{NaCl} 0,9 \%$ e $\mathrm{NaN}_{3} 0,1 \% \mathrm{com} \circ \mathrm{pH}$ ajustado para 5,5$)$. Após incubação de 18 horas a $4^{\circ} \mathrm{C}$ foi adicionado $500 \mu \mathrm{L}$ de solução de carvão ativado-dextran $(0,5 \%$ de carvão ativado e $0,05 \%$ de dextran em solução tampão de tricina) resfriada. Os tubos foram então incubados por 20 minutos a $4^{\circ} \mathrm{C}$, centrifugados $(2000 \mathrm{rpm}$ ) por 20 minutos e $700 \mu \mathrm{L}$ de sobrenadante foi adicionado a frascos de cintilação (vials de $20 \mathrm{~mL}$ ) contendo $7 \mathrm{ml}$ de fluído de cintilação (980 mL de tolueno, $20 \mathrm{~mL}$ de metanol e $5 \mathrm{~g}$ de PPO $\left.-\mathrm{C}_{5} \mathrm{H}_{11} \mathrm{NO}\right)$ e submetidos a uma seqüência de contagens de 10 minutos cada no contador Beta (cintilador) Packard modelo 1550.

As dosagens de melatonina foram realizadas em oito ensaios e os parâmetros de qualidade do mesmo encontram-se na tabela 4. O limite de

\footnotetext{
${ }^{6}$ Sigma M-5250

${ }^{7}$ Stockgrand Ltd. ab/s/21-hp/s/704-8483

${ }^{8}$ Amershan pharmacia TRK 798
} 
detecção do ensaio foi $2,0 \mathrm{pg} / \mathrm{mL}$, e os coeficientes de variação inter-ensaio foi de $26,33 \%$.

Tabela 4. Coeficientes de variação intra-ensaio dos ensaios hormonais (RIE) para a melatonina.

\begin{tabular}{cc}
\hline Ensaio & C.V. intra ensaio (\%) \\
\hline 1 & 3,53 \\
2 & 2,47 \\
3 & 9,15 \\
4 & 0,43 \\
5 & 0,99 \\
6 & 5,87 \\
7 & 8,99 \\
8 & 1,19 \\
\hline
\end{tabular}

\subsection{Parâmetros de avaliação da atividade reprodutiva}

Para a avaliação da atividade reprodutiva das fêmeas, primeiramente monitoramos a atividade cíclica reprodutiva $(A C R)$ de todas as fêmeas, antes e após a introdução dos machos, através das concentrações plasmáticas de progesterona. Em seguida, considerando somente os animais que se encontravam em anestro antes da introdução dos machos, foi calculado os dias para cada um destes animais retornar a ACR. 


\subsubsection{Atividade cíclica reprodutiva (ACR) antes e após a introdução dos machos}

O monitoramento da atividade cíclica reprodutiva foi realizado através da determinação das concentrações plasmáticas de progesterona e das observações de estro através dos rufiões. As concentrações de $\mathrm{P}_{4}$ antes da introdução dos machos tiveram como objetivo identificar as fêmeas que estavam em atividade cíclica reprodutiva e as que se encontravam em anestro sazonal. De acordo com MINTON et al. (1990), valores plasmáticos de progesterona inferiores a $1 \mathrm{ng} / \mathrm{mL}$ podem caracterizar as fases de estro ou de anestro, enquanto valores superiores a $3 \mathrm{ng} / \mathrm{mL}$ caracterizam a fase de diestro (luteal) ou gestação. A fase de anestro diferencia-se da fase de estro quando as concentrações de progesterona permanecem baixas por um período superior a dez dias.

\subsubsection{Retorno da atividade cíclica reprodutiva (em dias)}

Para avaliar o retorno da atividade cíclica reprodutiva foram considerados somente os animais que se encontravam em anestro (valores plasmáticos de $\mathrm{P}_{4}$ abaixo de $1 \mathrm{ng} / \mathrm{mL}$ por um período superior a dez dias) antes da introdução dos machos. A partir da presença dos machos, animais que apresentaram um aumento na concentração plasmática de $P_{4}$ (acima de $2 \mathrm{ng} / \mathrm{mL}$ ), foram consideradas em atividade (retorno) cíclica reprodutiva.

Em algumas análises da ACR, além do fator tratamento, consideramos o fato do animal ter ganho ou perdido peso. Assim, os animais foram classificados em dois grupos, de acordo com o ganho de peso no período total do experimento: grupo dos que ganharam e grupos dos que perderam peso. 


\subsection{Delineamento experimental e Estatística}

Os dados foram analisados utilizando o procedimento GLM (General Linear Model) pelo "software" SAS (Statystical Analysis System), seguido pelo teste de Tukey para estabelecer a comparação entre médias. O nível de significância considerado para todas as análises foi de $10 \%(\alpha=0,10)$.

\subsubsection{Ganho de Peso}

O ganho de peso foi feito em delineamento inteiramente casualizado (tabela 5), em esquema fatorial $2 \times 3$, sendo 2 tratamentos nutricionais e 3 raças.

Tabela 5. Delineamento experimental para o ganho de peso total, de ovelhas Santa Inês, Romney Marsh e Suffolk.

\begin{tabular}{lc}
\hline \multicolumn{1}{c}{ Causas de Variação } & Graus de Liberdade \\
\hline Tratamento (T) & 1 \\
Raça (R) & 2 \\
Interação T x R & 2 \\
Resíduo & 30 \\
\hline TOTAL & 35 \\
\hline
\end{tabular}




\subsubsection{Número de dias para retornar a atividade cíclica reprodutiva}

Para a resposta número de dias para retornar a atividade cíclica reprodutiva após a introdução dos machos, foi feito um delineamento inteiramente casualizado, em arranjo fatorial $2 \times 3$, considerando os fatores tratamento, raça e interação tratamento $\mathrm{x}$ raça (análise I). Porém, para efeitos da atividade cíclica reprodutiva é interessante avaliar o fato do animal ter ganho ou perdido peso. Assim, como os efeitos dentro de um mesmo tratamento não foram os mesmos para todos animais, foi realizada uma segunda análise tendo como causas de variação o peso (classificando os animais em ganho ou perda de peso), a raça e a interação peso $\mathrm{x}$ raça. Para a análise desta resposta (número de dias para retornar a atividade cíclica reprodutiva), foram considerados somente os animais que não estavam ciclando antes da introdução dos machos, ou seja, que estavam em anestro sazonal, pois não há sentido incluir os animais que estavam em atividade cíclica reprodutiva. Os animais que não retornaram a atividade cíclica reprodutiva após a introdução dos machos e durante toda a sua permanência de 40 dias, foi considerado como valor 39 . 
Tabela 6. Delineamento experimental para o número de dias para retornar a atividade cíclica reprodutiva após introdução dos machos de ovelhas Santa Inês, Romney Marsh e Suffolk.

\begin{tabular}{cccc}
\hline \multicolumn{2}{c}{ Análise I } & \multicolumn{2}{c}{ Análise II } \\
\hline Causas de Variação & Graus de Liberdade & Causas de Variação & Graus de Liberdade \\
\hline Tratamento $(\mathrm{T})$ & 1 & Peso $(\mathrm{P})$ & 1 \\
Raça (R) & 2 & Raça (R) & 2 \\
Interação T x R & 2 & Interação P x R & 2 \\
Resíduo & 30 & Resíduo & 30 \\
\hline Total & 35 & Total & 35 \\
\hline
\end{tabular}

\subsubsection{Concentrações plasmáticas de melatonina}

Os valores referentes às concentrações plasmáticas de melatonina foram analisados por um delineamento de parcelas sub-sub-divididas. Foram feitas três análises de variância, sendo uma para cada um dos períodos de colheita das amostras de sangue (tabelas 7, 8 e 9). Nos períodos 1 e 2 foram descartados os dados relativos aos horários de colheita das 8:00, 12:00 e 16:00 horas devido à problemas no momento da realização das análises hormonais. 
Tabela 7. Delineamento experimental das concentrações plasmáticas de melatonina do período 1 (antes do início do tratamento em 22/09/2001) de ovelhas Santa Inês, Romney Marsh e Suffolk.

\begin{tabular}{ll}
\hline \multicolumn{1}{c}{ Causas de Variação } & Graus de Liberdade \\
\hline Tratamento (T) & 1 \\
Animal dentro de T - Resíduo (a) & 4 \\
\hline Raça (R) & 2 \\
Tx R & 2 \\
Animal (T x R) - Resíduo (b) & 10 \\
\hline Horário (H) & 6 \\
Hx T & 6 \\
Hx R & 12 \\
Hx T x R & 12 \\
Resíduo (c) & 84 \\
\hline Total & 139 \\
\hline
\end{tabular}

Tabela 8. Delineamento experimental das concentrações plasmáticas de melatonina do período 2 (antes da introdução dos machos em 20/10/2001) de ovelhas Santa Inês, Romney Marsh e Suffolk.

\begin{tabular}{lc}
\hline \multicolumn{1}{c}{ Causas de Variação } & Graus de Liberdade \\
\hline Tratamento (T) & 1 \\
Animal dentro de T - Resíduo (a) & 4 \\
\hline Raça (R) & 2 \\
Tx R & 2 \\
Animal (T x R) - Resíduo (b) & 10 \\
\hline Horário (H) & 6 \\
H x T & 6 \\
H x R & 12 \\
H x T x R & 12 \\
Resíduo (c) & 84 \\
\hline Total & 139 \\
\hline
\end{tabular}


Tabela 9. Delineamento experimental das concentrações plasmáticas de melatonina do período 3 (final do período experimental em 01/12/2001) de ovelhas Santa Inês, Romney Marsh e Suffolk.

\begin{tabular}{lc}
\multicolumn{1}{c}{ Causas de Variação } & Graus de Liberdade \\
\hline Tratamento ( $\mathrm{T})$ & 1 \\
Animal dentro de T - Resíduo (a) & 4 \\
\hline Raça (R) & 2 \\
T x R & 2 \\
Animal (T x R) - Resíduo (b) & 10 \\
\hline Horário (H) & 9 \\
H x T & 9 \\
H x R & 18 \\
H x T x R & 18 \\
Resíduo (c) & 120 \\
\hline Total & 199 \\
\hline
\end{tabular}

\subsubsection{Duração da secreção noturna de melatonina}

Para as medidas de duração (em horas) da secreção noturna de melatonina, considerou-se o tratamento, a raça e a interação tratamento $\mathrm{x}$ raça como causas de variação utilizando o delineamento inteiramentre casualizado como delineamento experimental (tabela 10).

O início e o término da secreção de melatonina para cada animal, referentes às colheitas do terceiro período, foram definidos como o período compreendido entre o primeiro (horários de final do dia) e o último (horários de 
início do dia) valor maior que quatro vezes o desvio padrão da média dos valores basais obtidos durante a fase diurna. Quando os valores basais foram abaixo do limite de detecção do ensaio $(2,0 \mathrm{pg} / \mathrm{mL})$, essa duração foi calculada em função do primeiro e do último valor ser maior que duas vezes $(4,0 \mathrm{pg} / \mathrm{mL})$ o próprio limite de detecção, como descrito por ENGLISH et al. (1988). Dessa forma, a secreção inicia a partir de $4,0 \mathrm{pg} / \mathrm{mL}$. Quando animais apresentam concentrações abaixo de 4,0 pg/mL são considerados como valores basais. Para calcular a hora de início e término de secreção foi feita uma análise de regressão linear simples para cada animal

Tabela 10. Delineamento experimental para a duração da secreção de melatonina do período $3(01 / 12 / 2001)$ de ovelhas Santa Inês, Romney Marsh e Suffolk.

\section{Causas de Variação Graus de Liberdade}

Tratamento (T) 1

$\operatorname{Raça~}(\mathrm{R}) \quad 2$

Interação T x R 2

$\begin{array}{ll}\text { Resíduo } & 14\end{array}$

$\begin{array}{ll}\text { Total } & 19\end{array}$

O escotoperíodo, ou seja, a duração da fase noturna do dia, nos três períodos de colheita de sangue para dosagem de melatonina, foi calculado pelos horários de nascer e pôr do sol da referida data, obtidos na Academia da Força Aérea (Pirassununga/SP). 
3.10.5. Horário de início e término da secreção noturna de melatonina

Foram realizadas análises também para o horário de início (tabela 11) e término (tabela 12) da secreção noturna de melatonina, considerando o tratamento, a raça e a interação tratamento x raça como causas de variação, em delineamentos inteiramente casualizados.

Tabela 11. Delineamento experimental para o horário de início da secreção noturna de melatonina no período $3(01 / 12 / 2001)$ de ovelhas Santa Inês, Romney Marsh e Suffolk.

\begin{tabular}{lc}
\hline \multicolumn{1}{c}{ Causas de Variação } & Graus de Liberdade \\
\hline Tratamento $(\mathrm{T})$ & 1 \\
Raça $(\mathrm{R})$ & 2 \\
Interação T x R & 2 \\
Resíduo & 14 \\
\hline Total & 19 \\
\hline
\end{tabular}

Tabela 12. Delineamento experimental para o horário de término da secreção noturna de melatonina do período $3(01 / 12 / 2001)$ de ovelhas Santa Inês, Romney Marsh e Suffolk.

\begin{tabular}{lc}
\hline \multicolumn{1}{c}{ Causas de Variação } & Graus de Liberdade \\
\hline Tratamento (T) & 1 \\
Raça (R) & 2 \\
Interação T x R & 2 \\
Resíduo & 14 \\
\hline Total & 19 \\
\hline
\end{tabular}




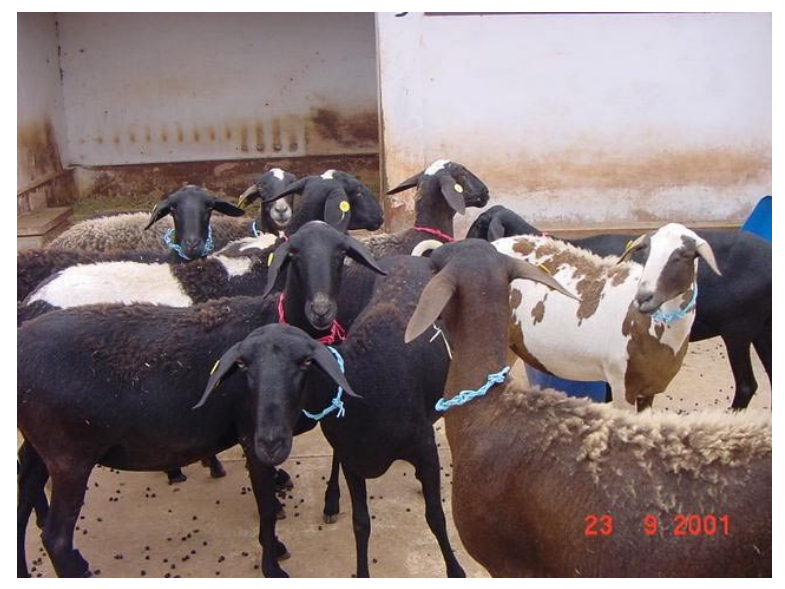

Figura 1. Fêmeas da raça Santa Inês

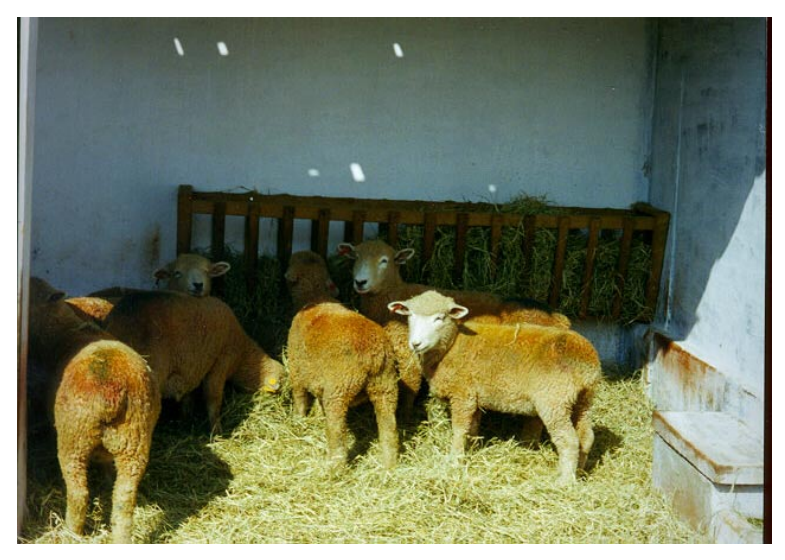

Figura 2. Fêmeas da raça Romney Marsh

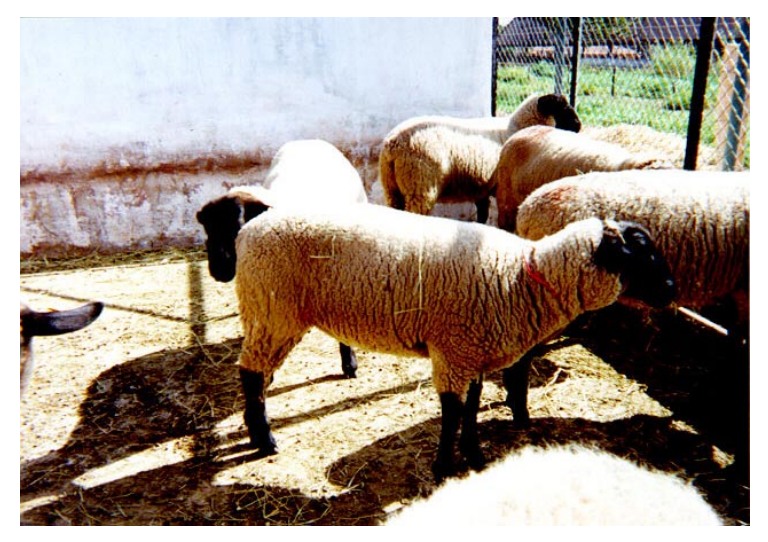

Figura 3. Fêmeas da raça Suffolk 


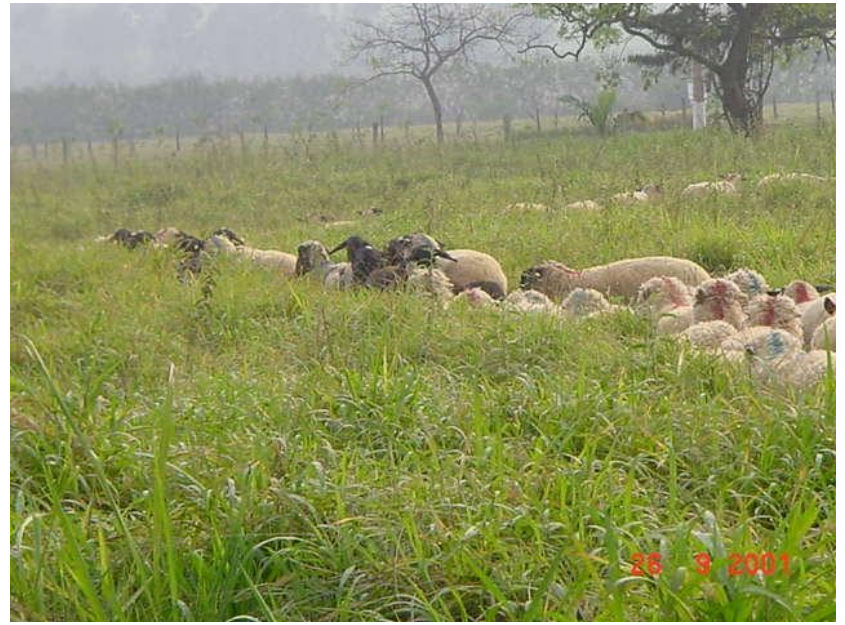

Figura 4. Animais no pasto no período diurno

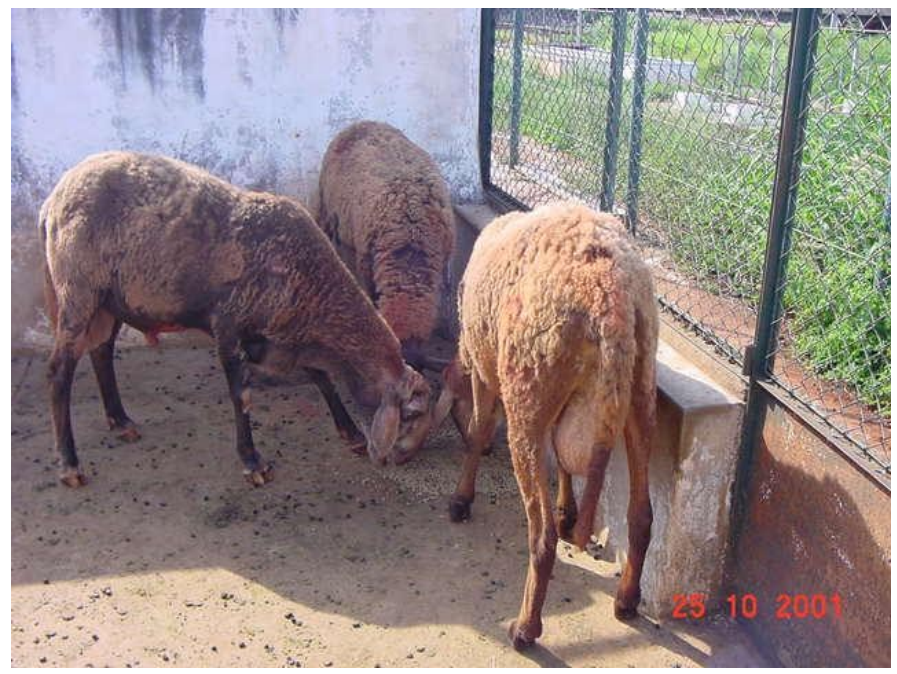

Figura 5. Machos vasectomizados
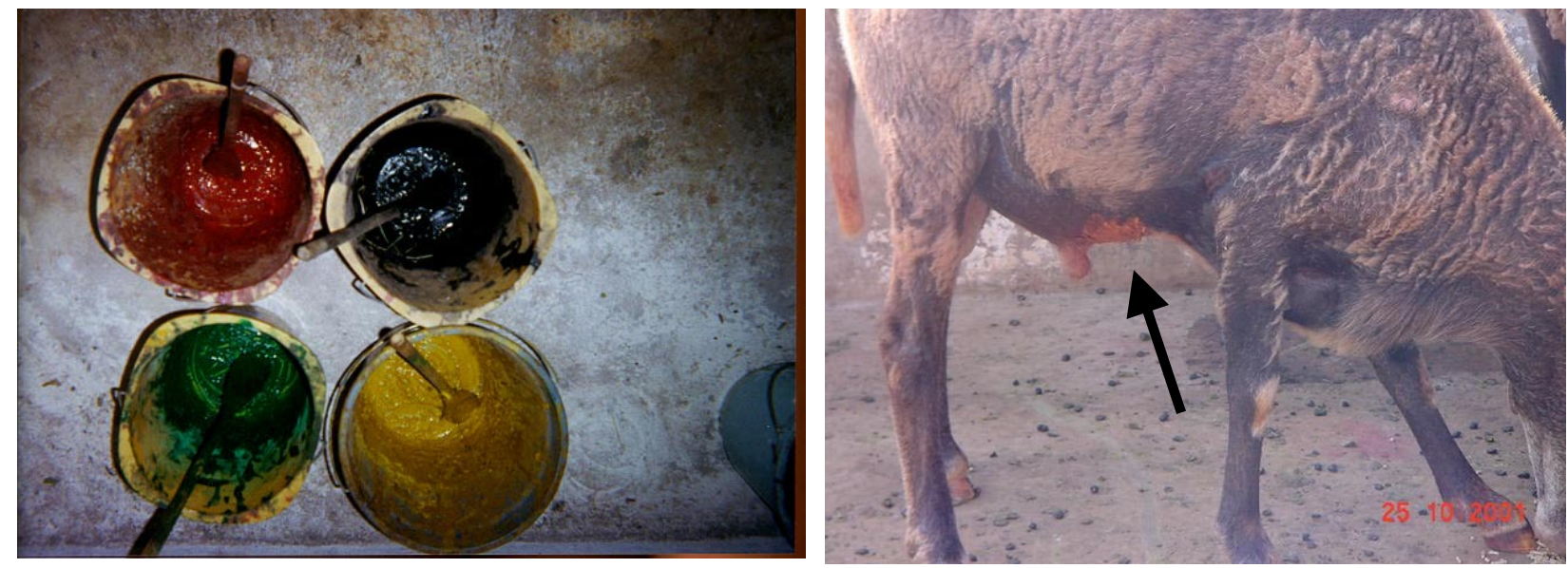

Figuras 6 e 7. Mistura de tinta utilizada na região prepucial dos machos 


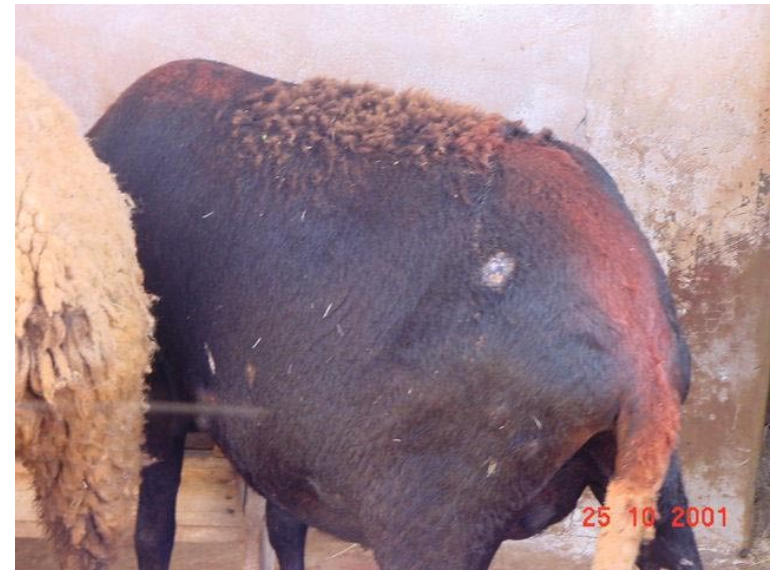

Figura 8. Fêmea da raça Santa Inês em estro, marcada pelo rufião
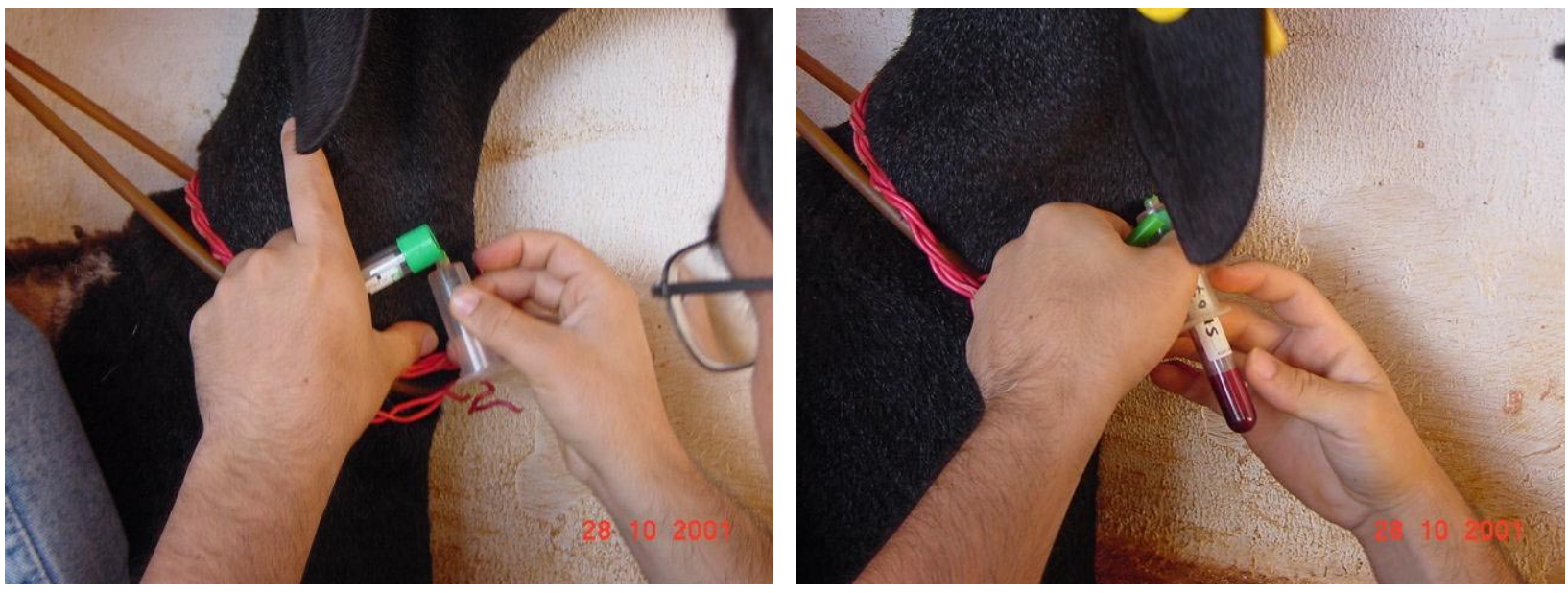

Figura 9. Colheita de sangue de uma fêmea Santa Inês
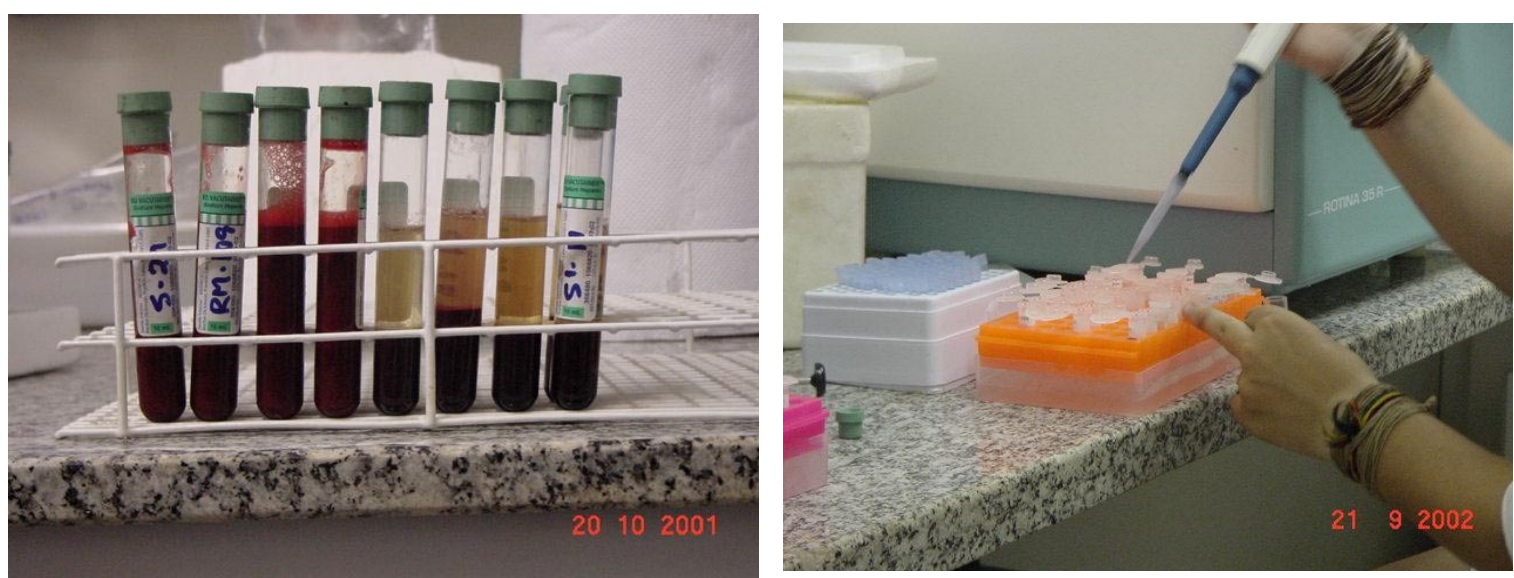

Figuras 10 e 11. Processamento do sangue e estocagem 

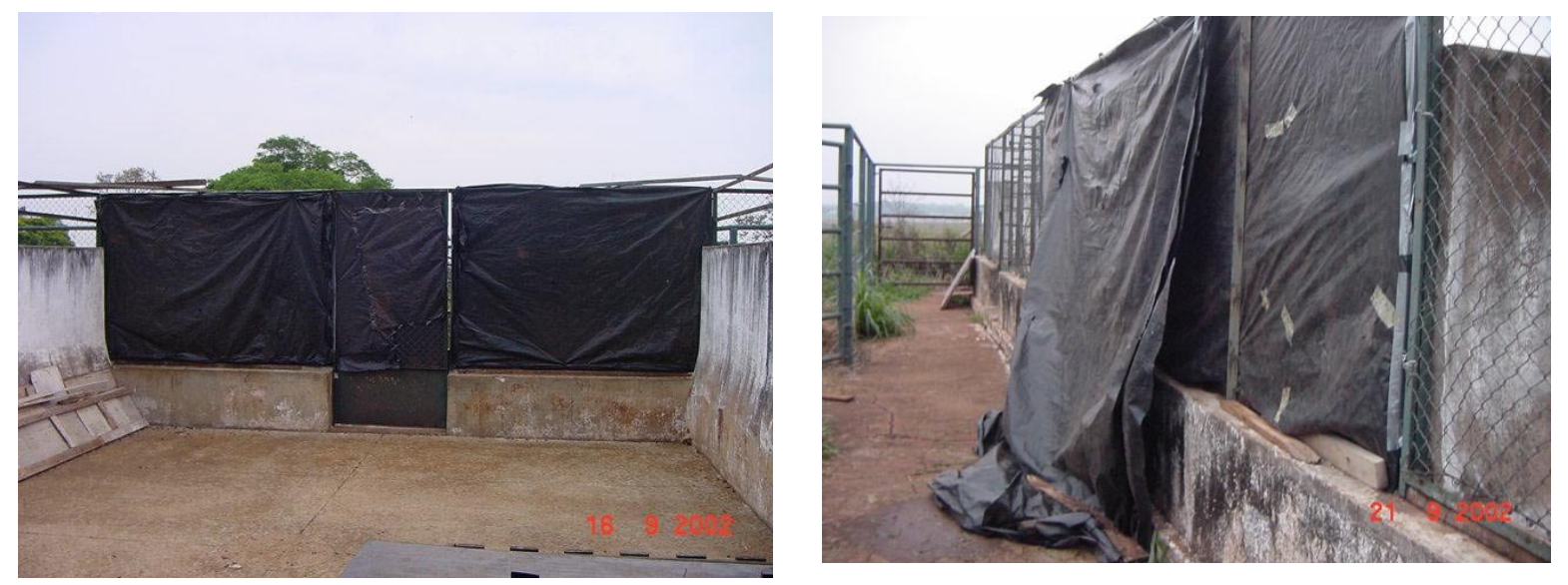

Figuras 12 e 13. Baia de colheita de sangue (com lona plástica para evitar a entrada de luzes externas). 


\section{RESULTADOS E DISCUSSÃO}

\subsection{Ganho de peso}

O objetivo de se avaliar o ganho de peso é o de verificar se os diferentes tratamentos nutricionais proporcionaram ganhos de peso diferentes, já que a principal causa de diferenças reprodutivas devido à nutrição está relacionado à perda ou ao ganho de peso. Os resultados expressos na tabela 13 indicam que houve efeito do tratamento nutricional $(P<0,001)$ e da raça $(P<0,001)$ no ganho de peso.

Tabela 13. Resultado da análise de variância para o ganho de peso de ovelhas das raças Santa Inês, Romney Marsh e Suffolk durante o período experimental (18/09/2001 a 01/12/2001).

\begin{tabular}{lc}
\hline \multicolumn{1}{c}{ Causas de Variação } & Valores de P \\
\hline Tratamento $(T)$ & $0,0006^{* * *}$ \\
Raça $(\mathrm{R})$ & $0,0007^{* * *}$ \\
Interação T x R & $0,3818^{\text {ns }}$ \\
\hline
\end{tabular}
ns = não significativo; ${ }^{* * *} \mathrm{P}<0,001$ 
Os resultados referentes às médias do ganho de peso total de ovelhas Santa Inês, Romney Marsh e Suffolk, sob regime de pastagem, submetidas à suplementação alimentar estão expressos nas tabelas 14 e 15 e figura 14 .

Tabela 14. Médias e desvio padrão do ganho de peso total de ovelhas Santa Inês, Romney Marsh e Suffolk, sob regime de pastagem, submetidas ou não à suplementação.

\begin{tabular}{cc}
\hline Tratamento & Média $(\mathrm{kg})$ \\
\hline 1 (suplementação) & $2,70 \pm 3,38^{\mathrm{a}}$ \\
2 (não suplementação) & $-1,07 \pm 3,17^{\mathrm{b}}$ \\
\hline
\end{tabular}

Letras diferentes diferem pelo teste de Tukey $(\alpha=0,10)$.

Tabela 15. Médias e desvio padrão do ganho de peso total de ovelhas de diferentes raças, sob regime de pastagem.

\begin{tabular}{cc}
\hline Raça & Média (kg) \\
\hline Santa Inês (SI) & $-2,05 \pm 3,18^{\mathrm{a}}$ \\
Romney Marsh (RM) & $0,63 \pm 2,17^{\mathrm{ab}}$ \\
Suffolk (SU) & $2,85 \pm 3,87^{\mathrm{b}}$ \\
\hline
\end{tabular}

Letras diferentes diferem pelo teste de Tukey $(\alpha=0,10)$.

Como esperado, a suplementação teve efeito $(P<0,001)$ no ganho de peso, ou seja, os animais que receberam concentrado ganharam em média $2,70 \mathrm{~kg}$ enquanto os que não foram suplementados perderam 1,07 kg de peso vivo (PV). Entretanto, o fator raça também influenciou $(P<0,001)$ o ganho de peso: houve diferenças somente entre as fêmeas das raças Santa Inês e 
Suffolk. Enquanto a SI perdeu em média $2,05 \mathrm{~kg}$, as fêmeas SU ganharam em média 2,85 kg de PV. Isto não reflete a realidade das exigências nutricionais destas raças, pois a raça SU é mais exigente que a raça SI. Uma hipótese para este fato é a realização de uma tosquia durante o período experimental, o que pode ter favorecido o ganho de peso das fêmeas lanadas (RM e SU). Após a tosquia, há uma tendência dos animais ganharem mais peso, devido a um aumento na ingestão de MS e/ou desvio dos nutrientes para o ganho de peso corporal que antes era utilizado para a produção de lã (SILVA SOBRINHO et al., 1996). Outra hipótese seria a ocorrência de dominância durante o pastejo. Segundo HAFEZ e SCOTT (1962) e FRASER e BROOM (1997), existe uma relação de dominância entre os animais dentro de raças e principalmente, entre raças, quando o pastejo ocorre em áreas relativamente pequenas ou em condições de escassez de alimentos. A escassez de alimento não ocorreu, pois uma disponibilidade de 1,70 a 1,90 tonelada MS/ha ou 1,20 a 1,30 tonelada MS/piquete é uma quantidade suficiente para atender 36 ovelhas (ou 7 - 9 UA) (CARVALHO et al, 2002). Provavelmente, o fator limitante tenha sido a área de pastejo, já que cada piquete era de 0,7 ha, e todos animais permaneciam juntos no mesmo piquete, favorecendo a ocorrência de dominância entre os mesmos.

Apesar da interação tratamento $x$ raça não ter sido significativa, a figura 14 auxilia a compreensão de alguns fatos ocorridos, que serão expostos futuramente. 


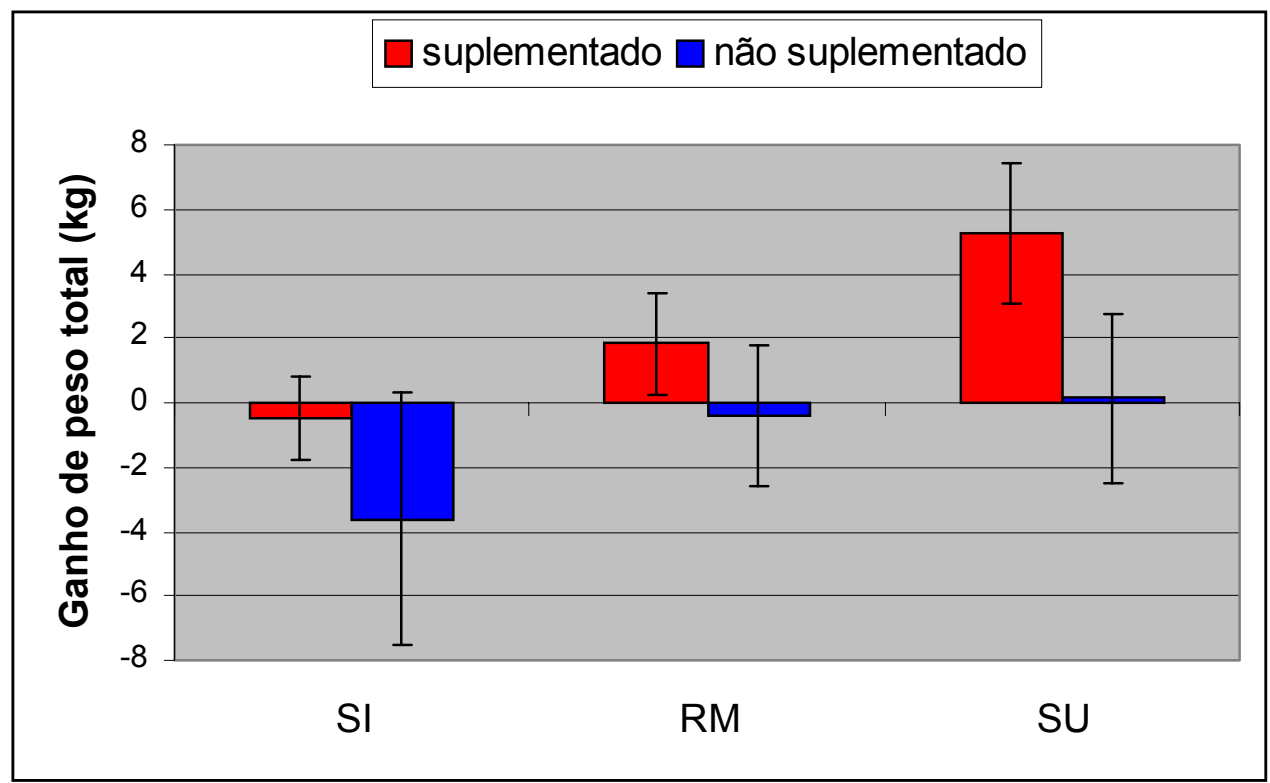

Figura 14. Médias e desvio padrão do ganho de peso total $(\mathrm{kg})$ de fêmeas Santa Inês (SI), Romney Marsh (RM) e Suffolk (SU) de acordo com os tratamentos nutricionais, durante todo o período experimental. 


\subsection{Concentrações plasmáticas de progesterona e atividade cíclica reprodutiva}

Os resultados referentes à atividade cíclica reprodutiva, por tratamento, das ovelhas Santa Inês, Romney Marsh e Suffolk estão expressos na tabela 16. Antes da introdução dos machos, somente $40 \%$ das ovelhas Santa Inês suplementadas (figura 15) e 60\% das não suplementadas (figura 16) estavam em atividade cíclica reprodutiva, como demonstram as concentrações plasmáticas de progesterona. Depois da introdução do macho, todas as fêmeas Santa Inês estavam em atividade cíclica reprodutiva, independente do tratamento nutricional oferecido (figuras 15 e 16). Todos os animais da raça Romney Marsh estavam em anestro, antes e após a introdução dos machos (tabela 16), com concentrações plasmáticas de progesterona inferiores a 1 $\mathrm{ng} / \mathrm{mL}$ por um período superior a dez dias. Considerando as fêmeas Suffolk antes da introdução do macho, 12,5\% das fêmeas suplementadas (tabela 16 e figura 17) estavam em atividade cíclica reprodutiva enquanto que o grupo não suplementado (tabela 16 e figura 18), todas as fêmeas estavam em anestro. Quando os machos foram introduzidos, $12,5 \%$ das fêmeas suplementadas (a mesma fêmea que já estava ciclando anteriormente) ainda permaneciam em atividade reprodutiva (tabela 16 e figura 17) e 57,1\% das não suplementadas retornaram a atividade cíclica reprodutiva (tabela 16 e figura 18).

Para facilitar a apresentação e discussão dos resultados, os animais receberam uma classificação (grupos) considerando a atividade cíclica reprodutiva antes e após a introdução dos machos, de acordo com a tabela 17. 
Tabela 16. Quantidade de animais (e \% por raça) por tratamento e por raça em atividade cíclica reprodutiva antes e após a introdução dos machos.

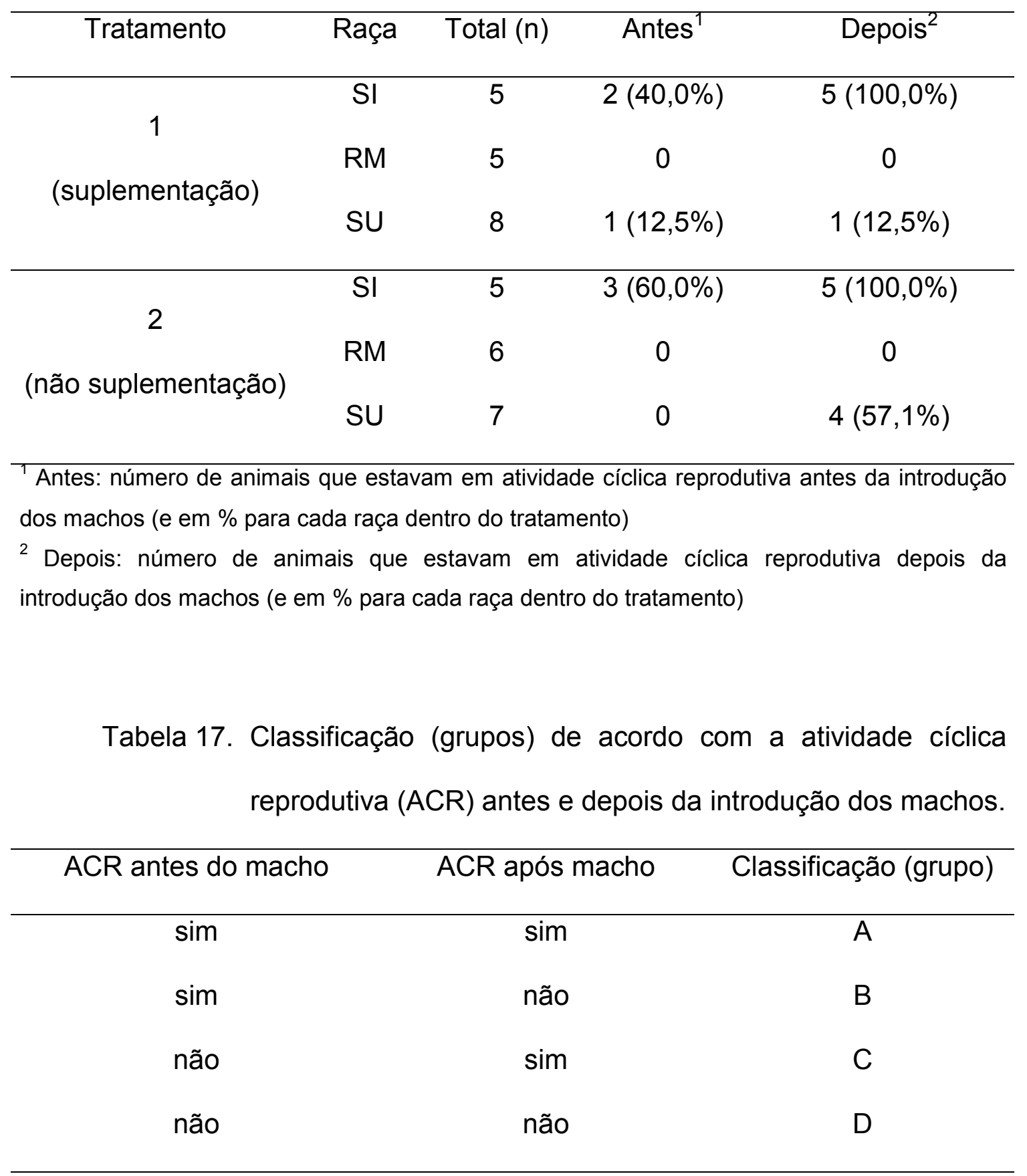




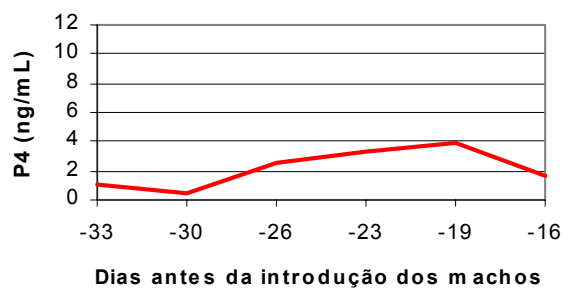

SI 07

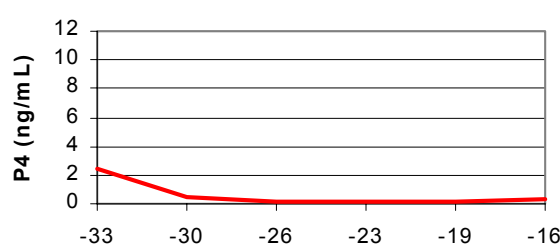

Dias antes da introdução dos m achos

SI 10

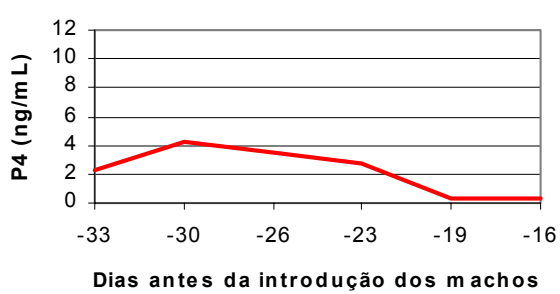

SI 11

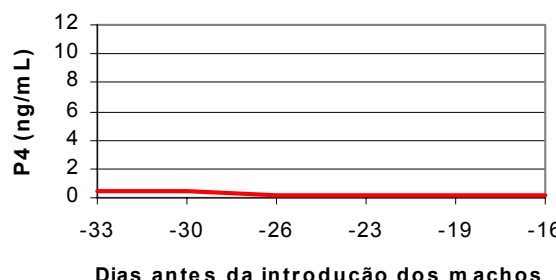

SI 15

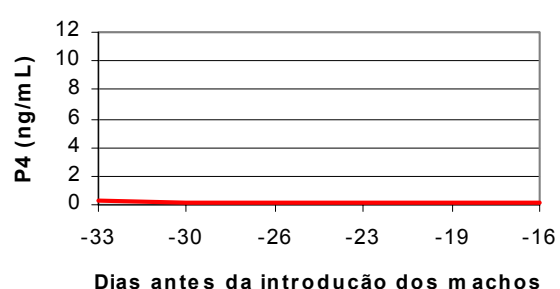

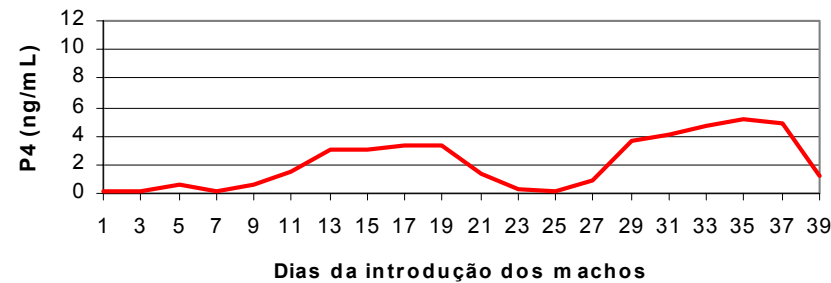

SI 07

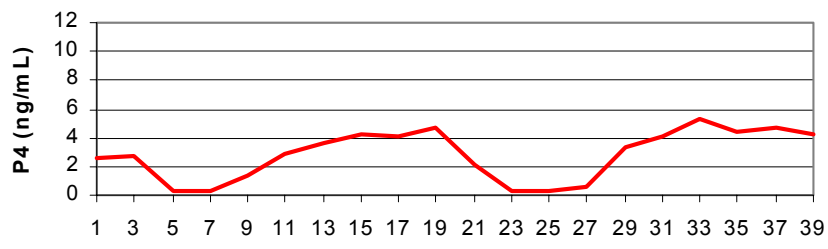

Dias da introdução dos $m$ achos

SI 10

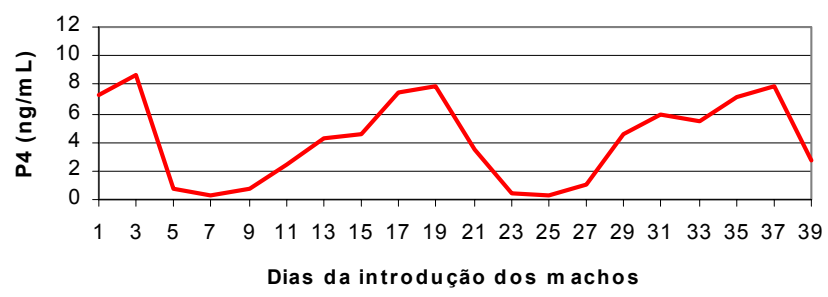

SI 11

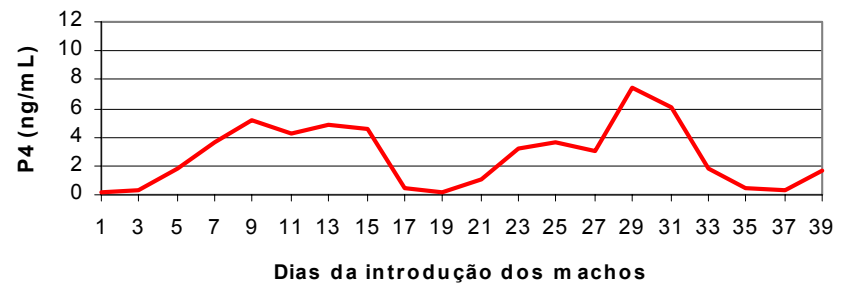

SI 15

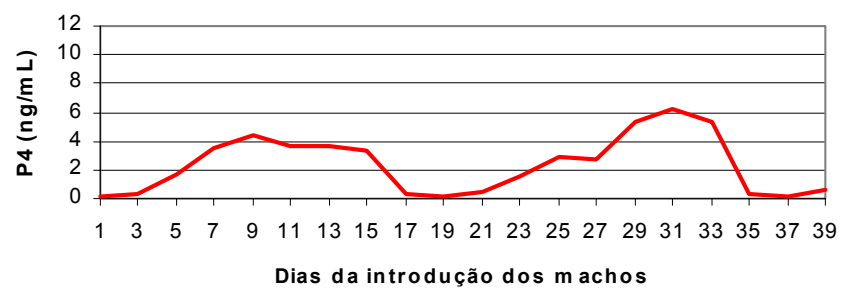

Figura 15. Concentrações plasmáticas de progesterona (P4) por animal antes e após a introdução dos machos das fêmeas Santa Inês do grupo suplementado. 


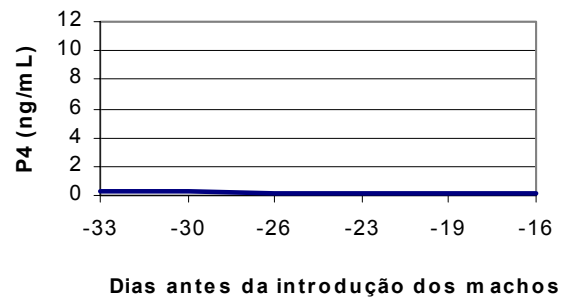

SI 09

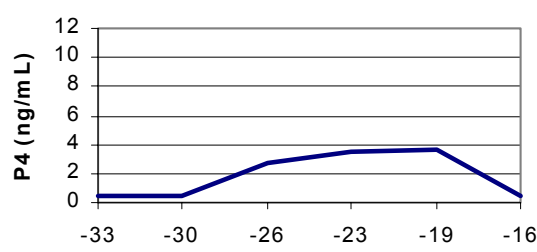

Dias antes da introdução dos m achos

SI 12

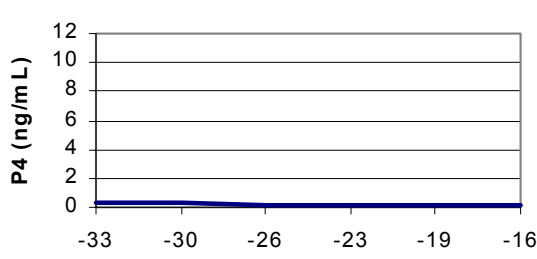

Dias antes da introdução dos machos

SI 13

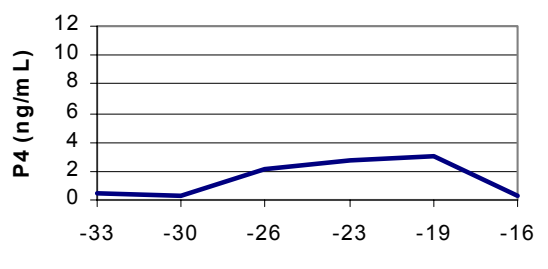

Dias antes da introdução dos m achos

SI 14

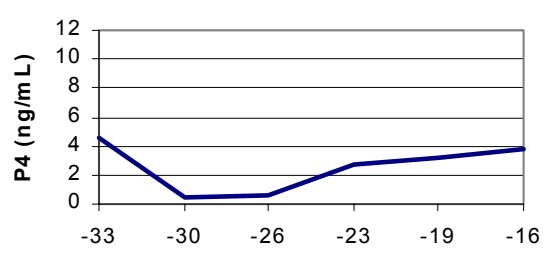

Dias antes da introdução dos machos

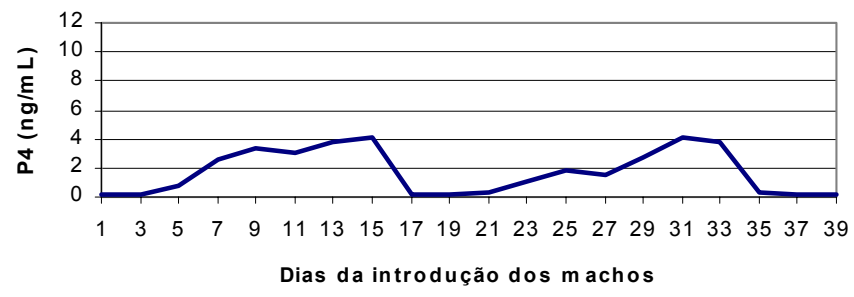

SI 09

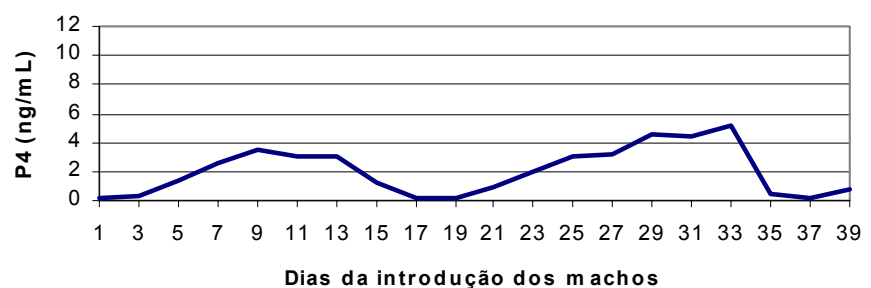

SI 12

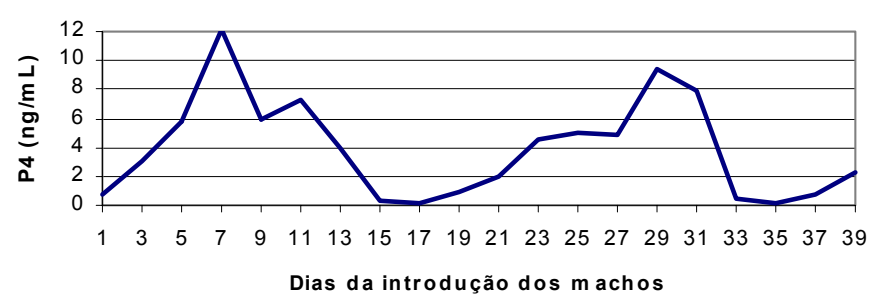

SI 13

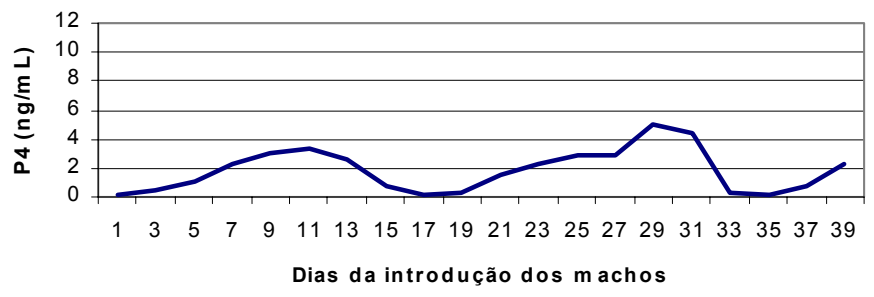

SI 14

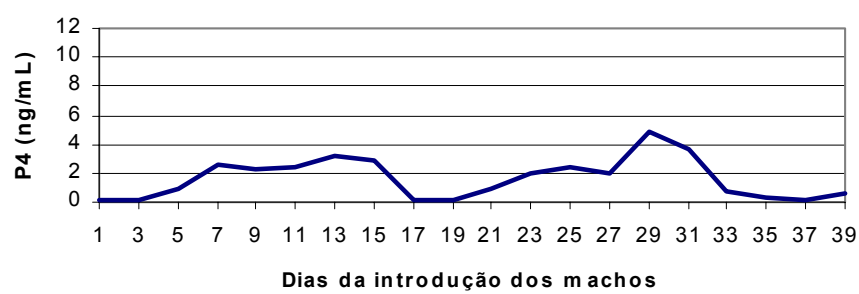

Figura 16. Concentrações plasmáticas de progesterona (P4) por animal antes e após a introdução dos machos das fêmeas Santa Inês do grupo não suplementado. 

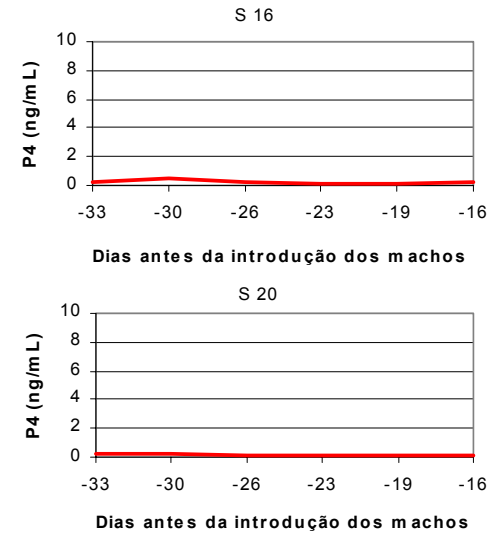

S 22

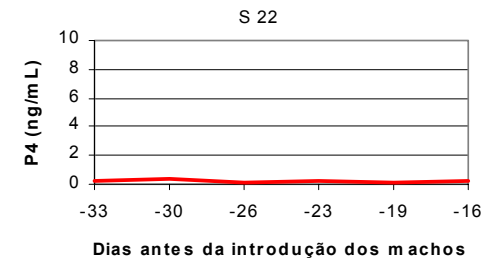

S 23

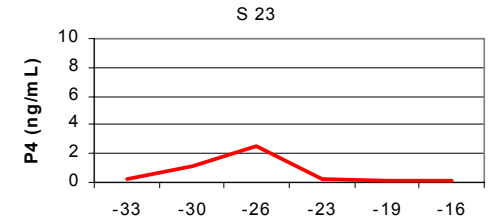

Dias antes da introdução dos $m$ achos

S 25

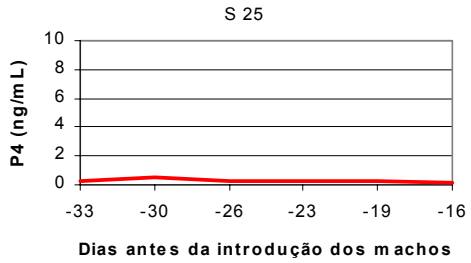

S 54

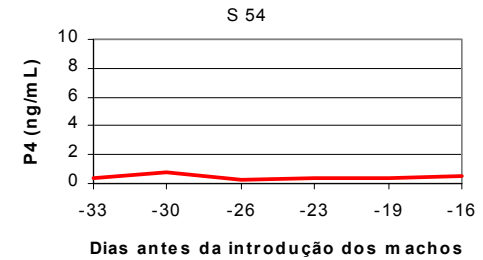

S 152

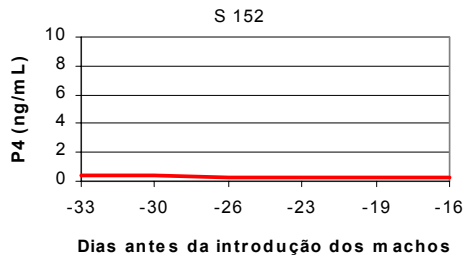

S 553

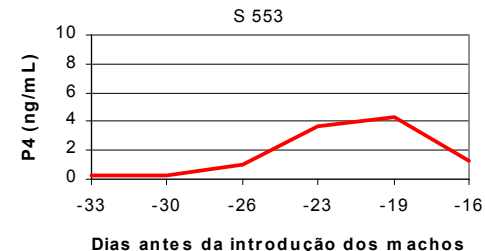

S 16
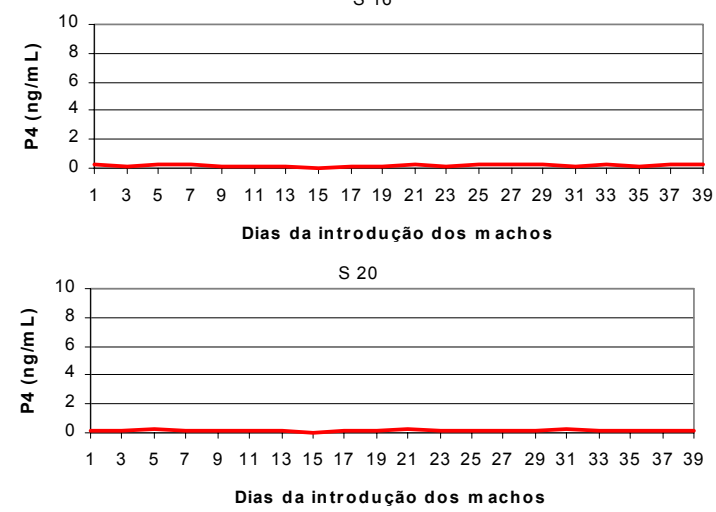

S 22

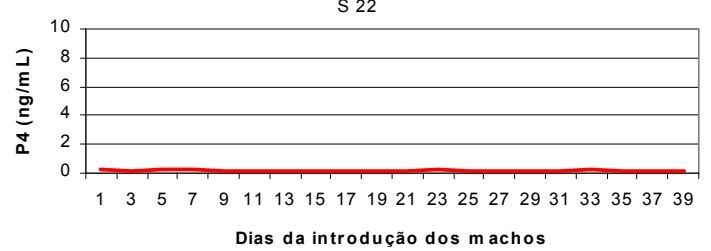

S 23

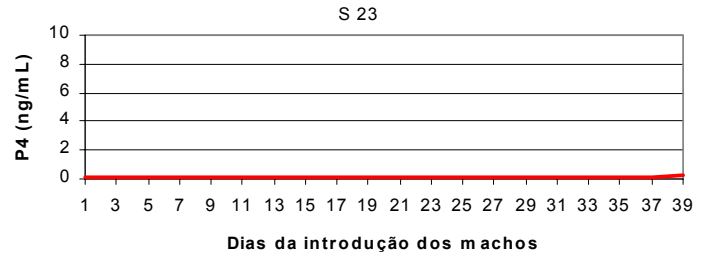

S 25

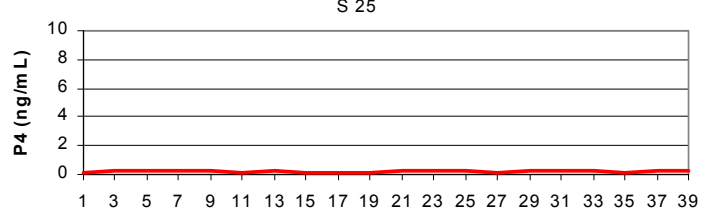

Dias da introdução dos $\mathrm{m}$ achos

S 54

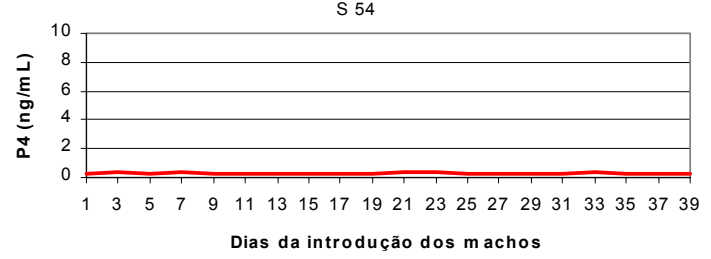

S 152

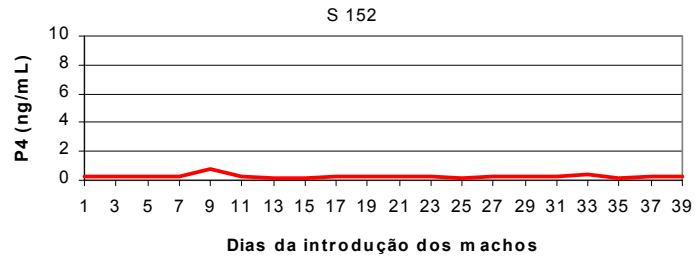

S 553

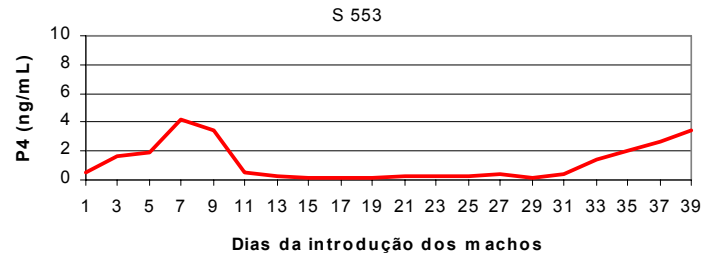

Figura 17. Concentrações plasmáticas de progesterona (P4) por animal antes e após a introdução dos machos das fêmeas Suffolk do grupo suplementado. 
S 17
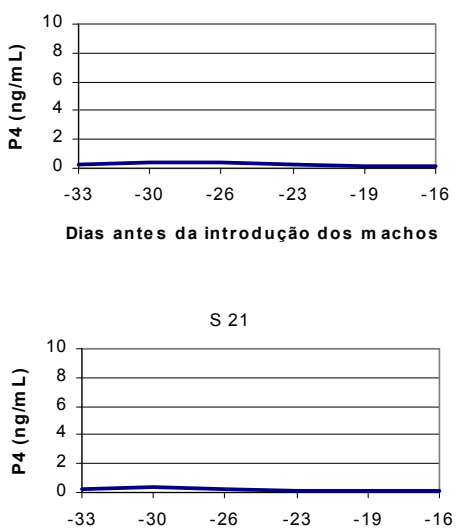

Dias antes da introdução dos $m$ achos
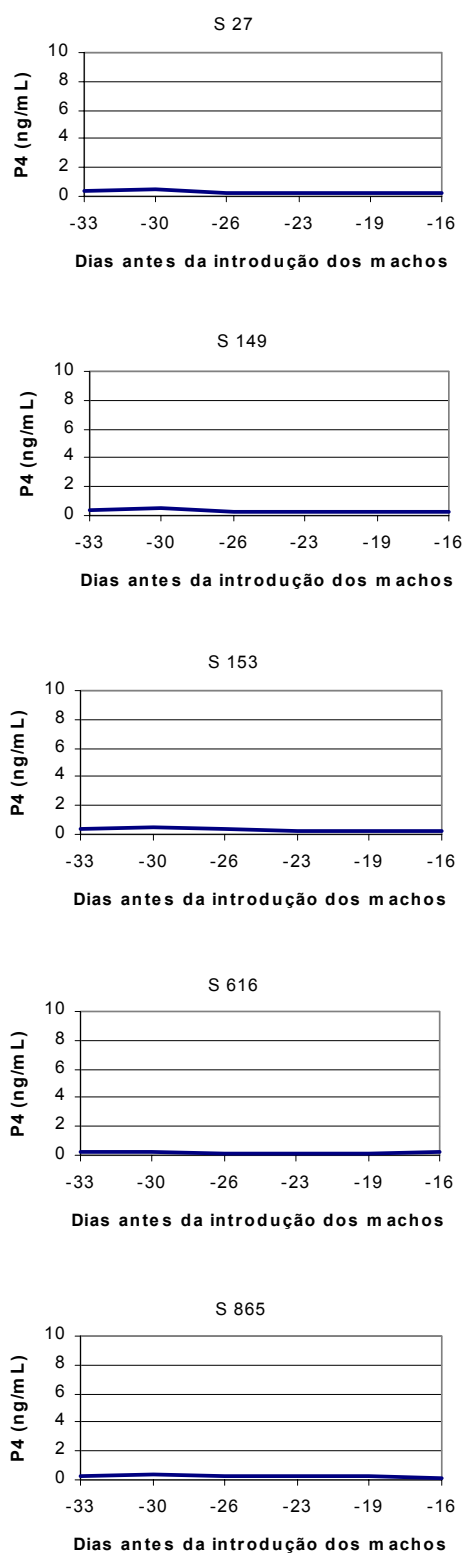

S 17

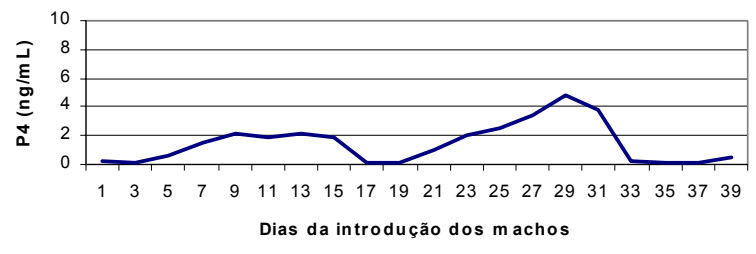

S 21

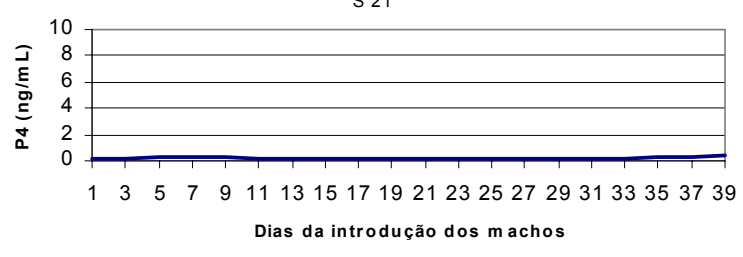

S 27

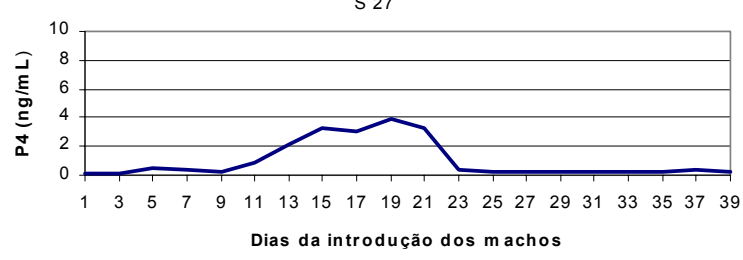

S 149

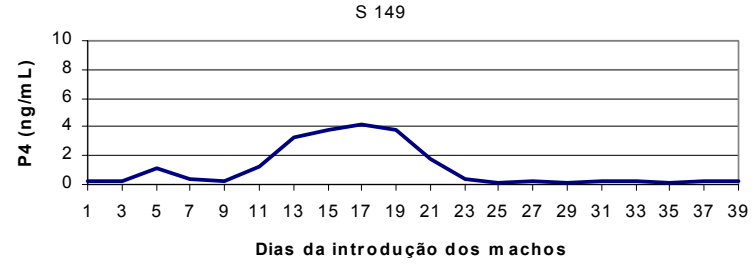

S 153

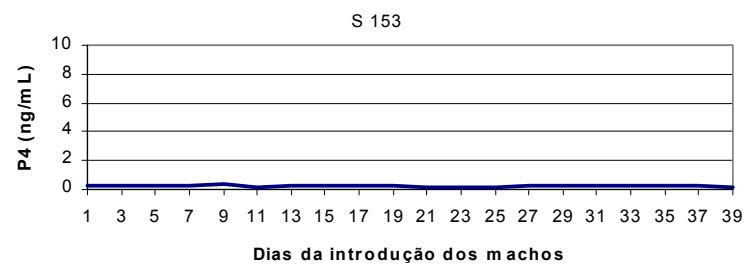

S 616

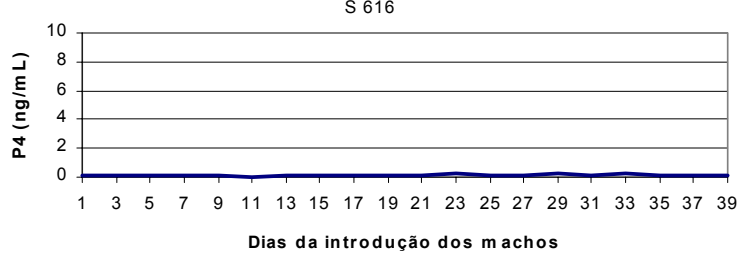

S 865

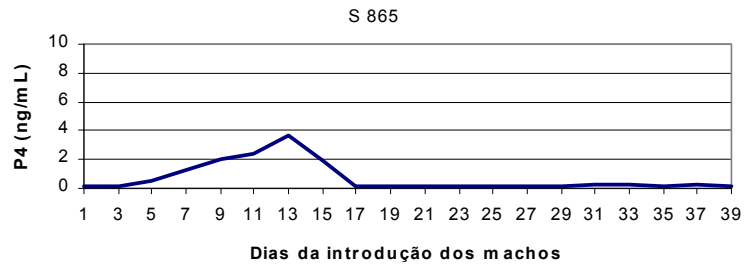

Figura 18. Concentrações plasmáticas de progesterona (P4) por animal antes e após a introdução dos machos das fêmeas Suffolk do grupo não suplementado. 
De acordo com as figuras apresentadas anteriormente (figuras 15, 16, 17 e 18) e a tabela 17, verificamos que o grupo B não teve ocorrência em nenhuma raça, ou seja, não houve nenhum animal que estivesse ciclando e que após a introdução dos machos interrompeu sua atividade cíclica reprodutiva.

A figura 19 ilustra o percentual de animais observado de cada grupo, dentro de cada raça, independente dos tratamentos nutricionais. O grupo de maior interesse é o C, em que os animais não estavam em atividade cíclica, e que após a introdução dos machos reiniciaram a atividade cíclica reprodutiva. Pela mesma figura, observamos que este grupo ocorreu em $50 \%$ dos animais da raça Santa Inês e $27 \%$ dos animais Suffolk. Se desdobrarmos este resultado de acordo com os tratamentos (figura 19), teremos que, o grupo C ocorreu em $60 \%$ e $40 \%$ das fêmeas Santa Inês dos tratamentos de suplementação e não suplementação, respectivamente, indicando que o retorno a atividade cíclica reprodutiva nesta raça se deveu ao efeito macho e que o tratamento nutricional potencializou esse efeito.

Nas fêmeas Santa Inês, o efeito macho foi eficiente em ambos os tratamentos nutricionais. Estes dados estão de acordo com MUKASAMUGERWA et al. (1993) que verificaram que, ovelhas originárias de regiões tropicais, consideradas como não estacionais, tendem a apresentar um curtíssimo período de diminuição da atividade cíclica reprodutiva, que independem das condições nutricionais. E de acordo com GORDON (1997) em animais de pouca ou nenhuma estacionalidade, a simples presença do macho é capaz de estimular a atividade cíclica ovariana. 


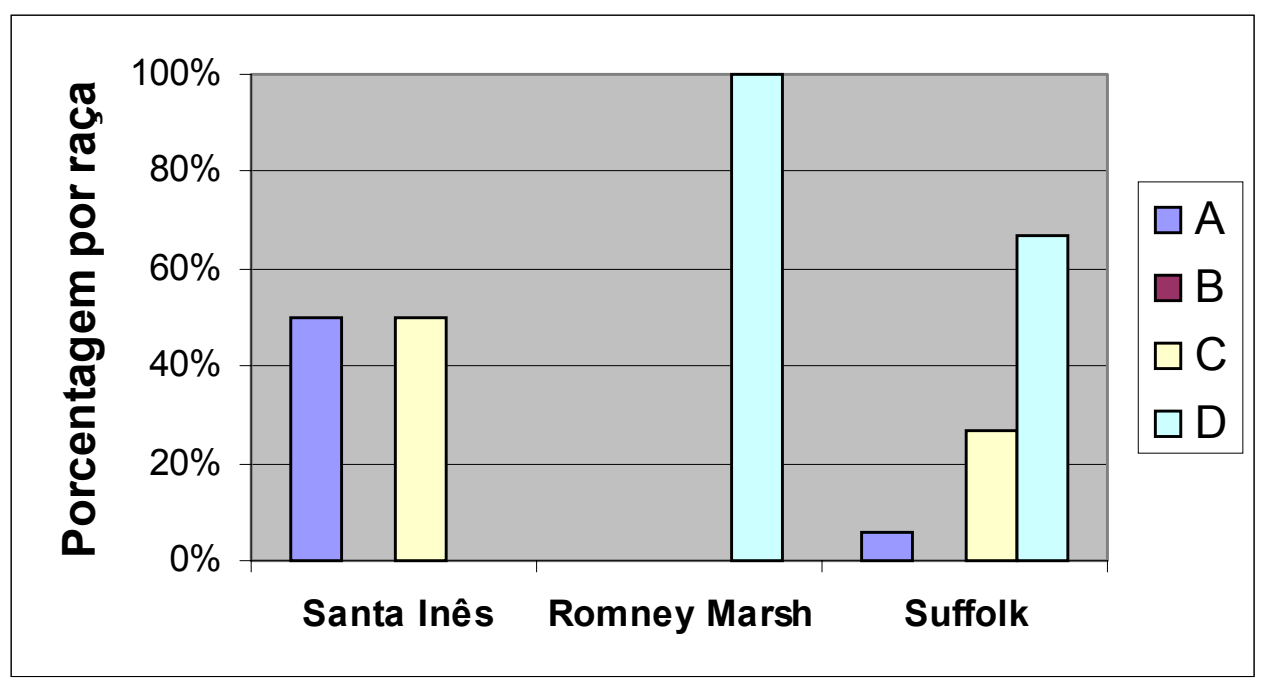

Figura 19. Percentual de animais dentro de cada raça, de acordo com a classificação por grupos quanto a ACR. As letras representam a classificação dos animais em grupos de acordo coma ACR antes e após a introdução dos machos, sendo A (fêmeas que estavam ciclando antes e após), B (fêmeas que estavam ciclando antes, mas não após), C (fêmeas que não estavam ciclando antes, mas que ciclaram após) e D (fêmeas que não estavam ciclando nem antes nem após).

Pelas figuras 19 e 20 verificamos que todas as fêmeas da raça Romney Marsh, independente do tratamento nutricional, não estavam em atividade cíclica reprodutiva antes da introdução dos machos nem após a introdução dos mesmos. Isto sugere que nesta raça a suplementação associada ao efeito macho não são capazes de ativar a atividade cíclica reprodutiva durante a fase de anestro sazonal. Isto está de acordo com ROSA et al. (2000) que, trabalhando com ovelhas estacionais da raça Northcountry Mule não conseguiram detectar aumento na proporção de ovelhas que ovularam na época de anestro em resposta ao efeito macho. De acordo com GORDON (1997), quanto maior a sensibilidade ao fotoperíodo (raças originárias de regiões temperadas), maior é o período de anestro, e menor será a resposta a 
estímulos como efeito macho e nutrição neste período de anestro. Já PÔRTO et al. (2001), obteve resultados satisfatórios no retorno da atividade cíclica reprodutiva em fêmeas Romney Marsh quando da associação do efeito macho com implantes de melatonina.
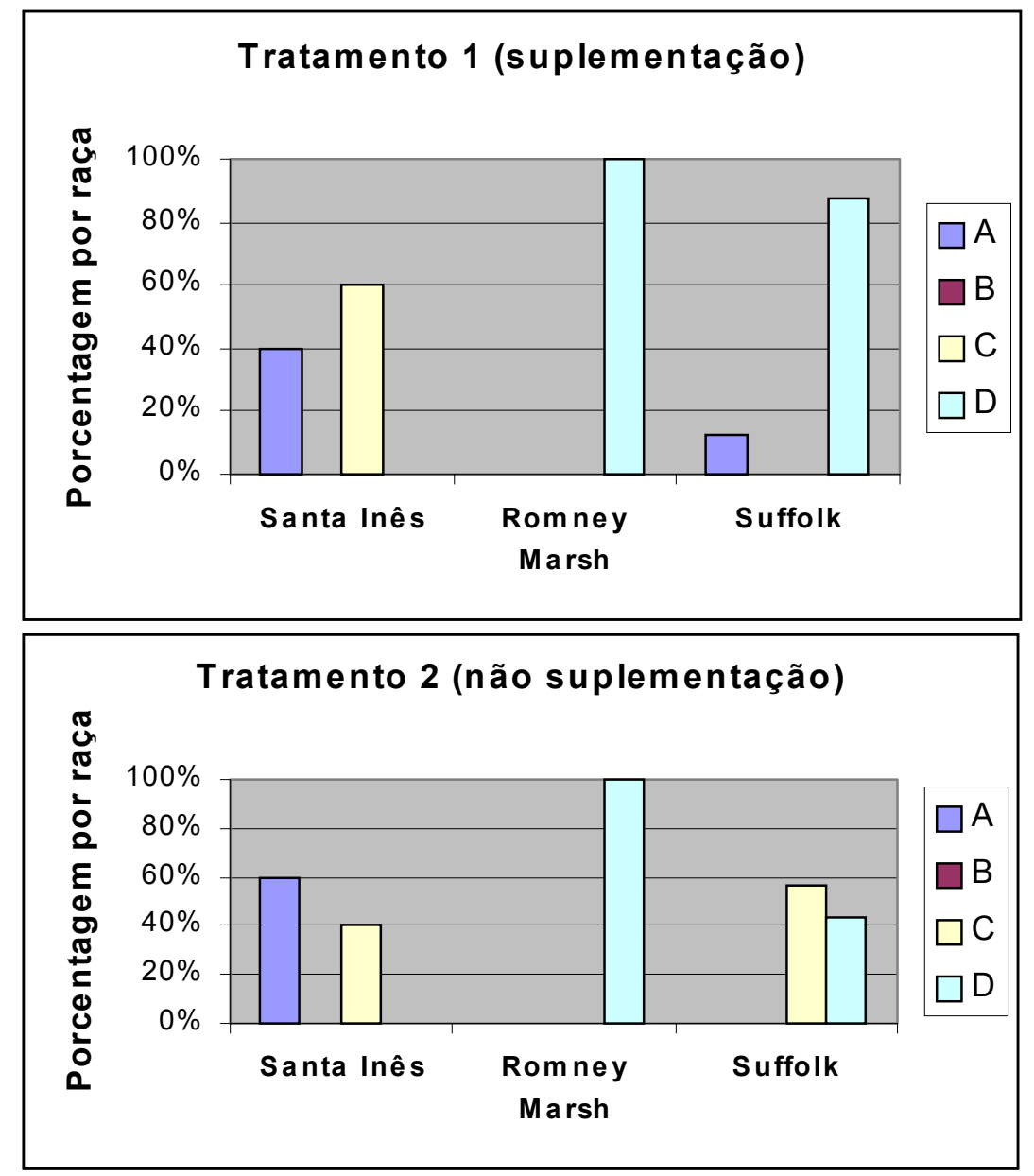

Figura 20. Desdobramento por tratamento: percentual de animais de cada raça de acordo com a classificação por grupos quanto à $A C R$. As letras representam a classificação dos animais em grupos de acordo coma ACR antes e após a introdução dos machos, sendo A (fêmeas que estavam ciclando antes e após), B (fêmeas que estavam ciclando antes, mas não após), C (fêmeas que não estavam ciclando antes, mas que ciclaram após) e D (fêmeas que não estavam ciclando nem antes nem após). 
Na raça Suffolk, dos oito animais do grupo suplementado, somente um animal estava em atividade cíclica antes da introdução dos machos. Após a introdução dos rufiões, somente a mesma fêmea continuou a ciclar (figura 17). Já no grupo de não suplementação (figura 18), nenhum dos sete animais encontravam em atividade cíclica antes, e após a introdução dos machos, quatro fêmeas iniciaram suas atividades cíclicas reprodutivas. Nesta raça o grupo C só ocorreu no grupo não suplementado ( $57 \%$ das fêmeas deste tratamento). Provavelmente, o que deve ter ocorrido com o grupo suplementado foi o excessivo ganho de peso no período $(5,23 \mathrm{~kg})$ que elevou a condição corporal de mediana a alta destas ovelhas, prejudicando a atividade cíclica ovariana. Nas fêmeas não suplementadas, o peso praticamente se manteve, com ganho de peso total de $0,13 \mathrm{~kg}$ no período, mantendo a condição corporal mediana. Assim, nas fêmeas Suffolk o efeito macho teve efeito, porém, somente nas fêmeas que mantiveram o peso ou a condição corporal mediana. Mas, a quantidade limitada de animais impossibilita conclusões mais precisas.

Das quatro fêmeas Suffolk que iniciaram sua ACR após a introdução dos machos, três retornaram ao anestro (concentrações plasmáticas de progesterona abaixo de $1 \mathrm{ng} / \mathrm{mL}$ por um período superior a dez dias). De acordo com LINDSAY e SIGNORET (1980), quando o efeito macho é realizado muito antes do início da próxima estação reprodutiva, é comum as fêmeas apresentarem uma ovulação sem comportamento de estro, e depois retornar a condição de anestro. Provavelmente esta deve ser a explicação para o fato observado no experimento, já que COELHO (2001) observou que as fêmeas Suffolk, após período de anestro em novembro e dezembro reiniciaram 
efetivamente sua ACR em março. Certamente, se o efeito macho fosse realizado mais próximo ao final do período de anestro, mais fêmeas retornariam a ACR e não retornariam a condição de anestro como observado. Assim, pode-se concluir que no presente trabalho o efeito macho funcionou parcialmente para as fêmeas Suffolk, porém os resultados foram "mascarados" com o ganho de peso dos animais, ao contrário de estudo realizado anteriormente (PÔRTO et al., 2001), em que o efeito macho foi eficaz em todos os animais. Vale ressaltar que no referido trabalho (PÔRTO et al., 2001), todas as fêmeas foram mantidas sob confinamento, recebendo a mesma alimentação balanceada. Já OTTO et al. (1998), trabalhando com fêmeas Suffolks no sul do Brasil, obtiveram resposta em $68,5 \%$ das borregas e $65,0 \%$ das ovelhas devido somente ao efeito macho. NUGENT III et al. (1988) já haviam concluído que o fator principal na resposta ao efeito macho é o racial. Semelhantemente, LINDSAY (1991) observou que quanto mais fotoreceptivo for o animal, menos intenso será o efeito, ou seja, ovelhas originárias de altas latitudes, que estão sob forte controle fotoperiódico não ovulam em resposta aos machos, exceto nas semanas que precedem a estação reprodutiva.

Diante disto, sugere-se que em raças pouco ou medianamente estacionais, só o efeito macho é capaz de estimular o retorno da atividade cíclica reprodutiva. E em raças mais estacionais, o efeito macho por si só ou associado a nutrição não são capaz de anular ou diminuir tal estacionalidade, sendo necessário um estímulo maior, como tratamentos hormonais. 


\subsubsection{Retorno da atividade cíclica reprodutiva (em dias)}

O retorno da atividade cíclica reprodutiva foi calculado somente para os animais que estavam em anestro antes da introdução dos machos. O parâmetro avaliado foi o número de dias para a fêmea retornar a sua atividade cíclica reprodutiva (concentração plasmática de $\mathrm{P}_{4}$ acima de $2 \mathrm{ng} / \mathrm{mL}$ ) a partir da introdução dos machos. Para esta variável foram realizadas duas análises estatísticas (tabela 18), uma considerando o fator tratamento (análise I) e outra considerando o fator peso (análise II).

Tabela 18. Resultado da análise de variância para retorno da ACR, em ovelhas Santa Inês, Romney Marsh e Suffolk, considerando o fator tratamento (análise I) ou peso (análise II).

\begin{tabular}{lclc}
\hline \multicolumn{2}{c}{ Análise I } & \multicolumn{2}{c}{ Análise II } \\
Causas de Variação & Valores de P & Causas de Variação & Valores de P \\
\hline Tratamento $(\mathrm{T})$ & $0,0976^{*}$ & Peso $(\mathrm{P})$ & $0,0322^{*}$ \\
Raça (R) & $0,0001^{* * *}$ & Raça $(\mathrm{R})$ & $0,0001^{* * *}$ \\
Interação T x R & $0,0297^{*}$ & Interação P x R & 0,0379 * \\
\hline \multicolumn{2}{c}{ ns = não significativo; ${ }^{*} \mathrm{P}<0,1 ;{ }^{* * *} \mathrm{P}<0,001$} &
\end{tabular}

Verificamos que o tratamento $(P<0,1)$, o peso $(P<0,1)$, a raça $(P<0,001)$ e as interações $(P<0,1)$ tiveram efeito no número de dias para o animal retornar a ACR. A média para retorno a ACR foi de 32,2 e 27,0 dias para os tratamentos de suplementação e não suplementação, respectivamente (tabela 19). E para os animais que ganharam e perderam peso foram de 33,09 e 21,44 dias respectivamente (tabela 19). Notar que as maiores diferenças são encontradas 
quando analisamos o fator ganho de peso ao invés do tratamento. No presente trabalho o fato dos animais que perderam peso (ou não receberam suplementação) ter retornado a ACR primeiro que o grupo que ganhou peso (ou recebeu suplementação) reflete os dados dos animais Suffolk, que se encontravam em uma condição corporal média no início do experimento, e que ao final, teve um aumento nesta condição corporal, independente dos tratamentos. Isto está de acordo como citado anteriormente, que em animais de médio escore corporal, o aumento de peso (aumento de tecido adiposo) prejudica a atividade reprodutiva.

Tabela 19. Médias e desvio padrão de dias para retornar a ACR em ovelhas Santa Inês, Romney Marsh e Suffolk, por tratamento nutricional (análise I) e por ganho de peso (análise II).

\begin{tabular}{cc}
\hline Tratamento nutricional (análise I): & Média (dias) \\
\hline Suplementado & $32,2 \pm 14,14^{\mathrm{a}}$ \\
Não suplementado & $27,0 \pm 15,38^{\mathrm{b}}$ \\
\hline Ganho de peso (análise II): & $33,1 \pm 12,48^{\mathrm{a}}$ \\
\hline Ganho de peso & $21,4 \pm 17,11^{\mathrm{b}}$ \\
Perda de peso
\end{tabular}

Letras diferentes diferem pelo teste de Tukey $(P<0,1)$.

As raças se comportaram diferentemente quanto ao número de dias para retorno da ACR (tabela 20). Assim, na média, as fêmeas Santa Inês retornaram sua atividade cíclica reprodutiva após cinco dias da introdução dos machos, seguido da Suffolk (31 dias). Estas diferenças racias já foram 
discutidas anteriormente, em que animais com alto grau de estacionalidade, como Romney Marsh, não respondem ao efeito macho. As diferenças entre as raças Santa Inês e Suffolk pode ser explicado pelo fato da raça Santa Inês apresentar uma estacionalidade muito fraca, ou em alguns casos (como ocorreu na metade dos animais) não apresentar o anestro sazonal. Desta forma, o estímulo do efeito macho foi imediato, fazendo com que as fêmeas retornassem a ACR em 5 dias, na média. Vale lembrar que todas as fêmeas Santa Inês que se encontravam em anestro, retornaram a ACR, enquanto que na raça Suffolk, somente $4(28,5 \%)$ das 14 fêmeas em anestro retornaram a ACR.

Tabela 20. Médias e desvio padrão de dias para retornar a ACR de fêmeas Santa Inês e Suffolk.

\begin{tabular}{cc}
\hline Raça & Média (dias) \\
\hline Santa Inês & $5,0 \pm 2,83^{\mathrm{a}}$ \\
Suffolk & $31,0 \pm 13,17^{\mathrm{b}}$ \\
\hline
\end{tabular}

Letras diferentes diferem pelo teste de Tukey $(P<0,1)$.

Houve uma interação significativa entre raça e tratamento (análise I) e raça e peso (análise II). Desdobrando o fator tratamento (figura 21 A), verificamos que para o tratamento de suplementação as fêmeas SI tiveram uma menor média (5 dias) de dias para retorno da ACR do que as fêmeas SU (39 dias), sendo que neste tratamento, nenhum animal SU retornou a ACR. Já no tratamento 2 (não suplementação) as fêmeas de ambas as raças se comportaram diferentemente, tendo as fêmeas SI a menor média (5 dias), 
seguida pelas fêmeas SU (23 dias). Quando desdobramos a interação peso e raça (figura 21 B), a única diferença em relação ao primeiro teste é que dentre os animais que perderam peso, as fêmeas SU não diferiram estatisticamente das fêmeas SI.

A

Tratame nto 1 (suple me ntação)

Tratamento 2 (não suplementação)
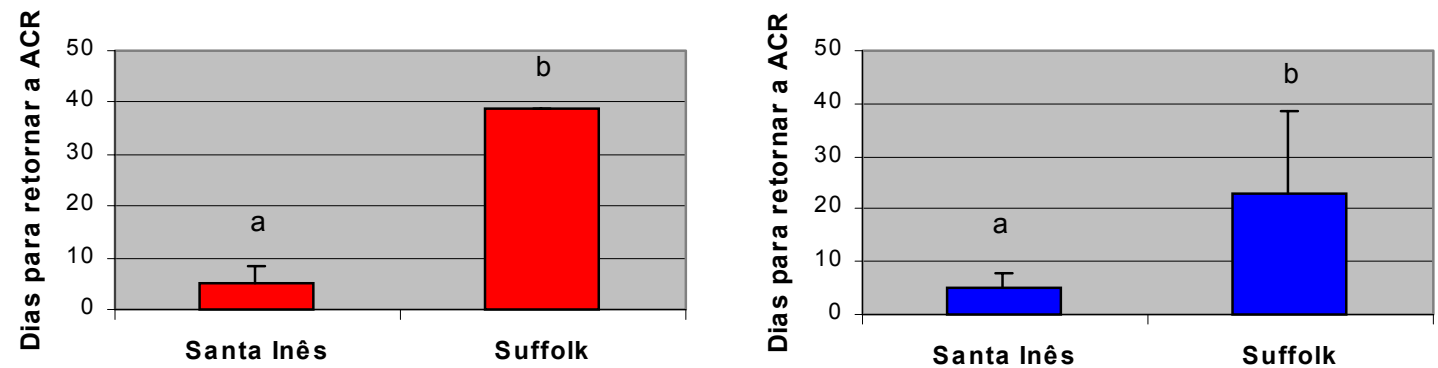

B

Ganho de Peso
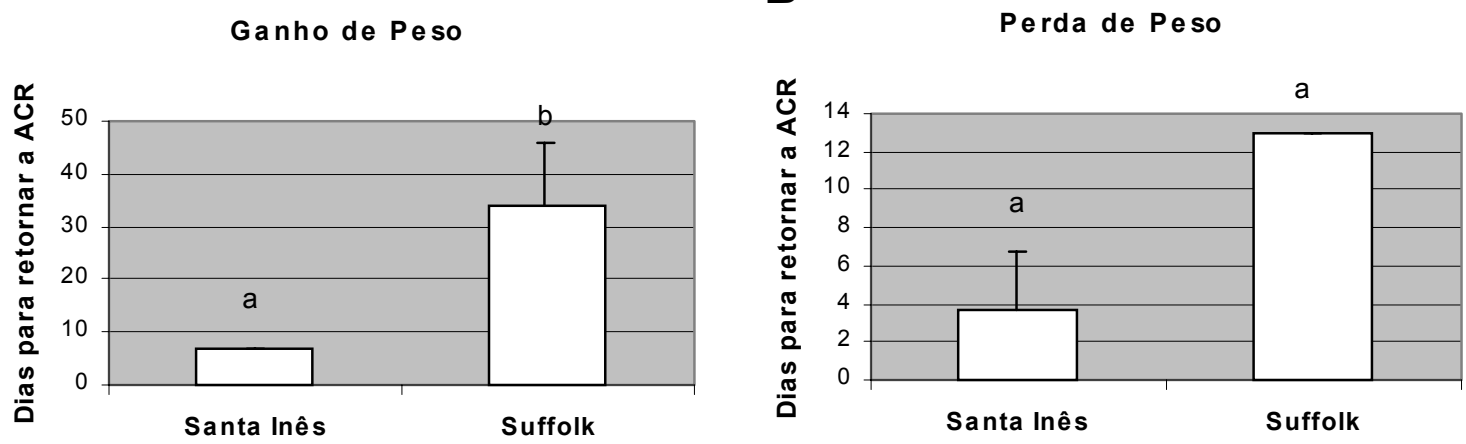

Figura 21. Desdobramento do fator tratamento (análise I - A) e do fator ganho de peso (análise II - B) dos dias para retornar a atividade cíclica reprodutiva (ACR) em ovelhas das raças Santa Inês, Romney Marsh e Suffolk. Letras diferentes diferem pelo teste de Tukey $(\mathrm{P}<0,10)$.

Em relação as raças (desdobramento de raças), somente a Suffolk se comportou diferentemente entre os tratamentos e/ou ganho de peso (figura 22). 
Ou seja, as fêmeas suplementadas levaram um maior número de dias (39) para o retorno da ACR em relação às fêmeas não suplementadas (23 dias). Semelhantemente, as fêmeas que ganharam peso apresentaram um retorno da ACR mais tardio (34 dias) quando comparadas com as que perderam peso (13 dias). Este fato pode ser explicado pelo excessivo ganho de peso das fêmeas Suffolk suplementadas.

A

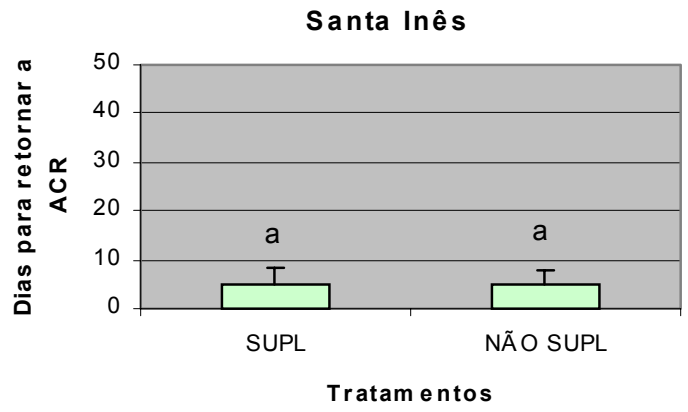

Suffolk

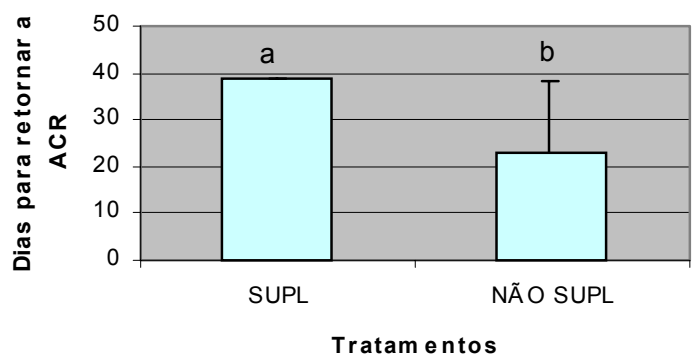

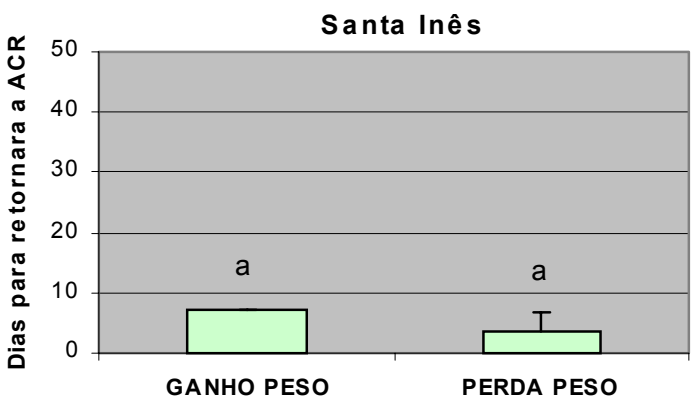

Suffolk

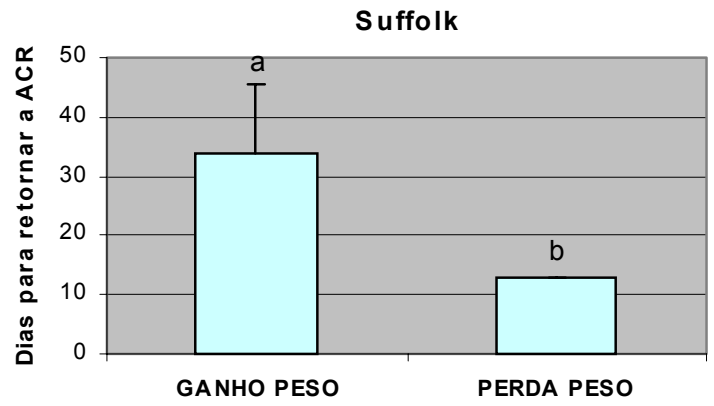

Figura 22. Desdobramento do fator raça por tratamento (análise I - A) e ganho de peso (análise II - B) dos dias para retornar a atividade cíclica reprodutiva (ACR) em ovelhas das raças Santa Inês e Suffolk. Letras diferentes diferem pelo teste de Tukey $(\mathrm{P}<0,10)$. 


\subsection{Concentrações plasmáticas de melatonina $(\mathrm{pg} / \mathrm{mL})$}

Os resultados das análises de variância referentes ao perfil diário das concentrações plasmáticas de melatonina $(\mathrm{pg} / \mathrm{mL})$ em três períodos: antes do tratamento nutricional (período 1), antes da introdução dos machos (período 2) e no final do experimento (período 3) estão expressos nas tabelas 21, 22 e 23, respectivamente.

Tabela 21. Resultados da análise de variância referente às concentrações plasmáticas de melatonina $(\mathrm{pg} / \mathrm{mL})$ de ovelhas das raças Santa Inês, Romney Marsh e Suffolk no período 1 (antes do início do tratamento nutricional em 22/09/2001).

\begin{tabular}{ll}
\hline \multicolumn{1}{c}{ Causas de Variação } & Valores de P \\
\hline Tratamento (T) & $0,8360^{\mathrm{ns}}$ \\
Raça (R) & $0,5152^{\mathrm{ns}}$ \\
Interação T x R & $0,7094^{\mathrm{ns}}$ \\
Animal dentro de (T x R) & $0,1199^{\mathrm{ns}}$ \\
Horário (H) & $0,2852^{\mathrm{ns}}$ \\
Interação H x T & $0,9634^{\mathrm{ns}}$ \\
Interação H x R & $0,8822^{\mathrm{ns}}$ \\
Interação H x T x R & $0,8993^{\mathrm{ns}}$ \\
\hline \multicolumn{1}{c}{ ns = não significativo } &
\end{tabular}
ns = não significativo

No período 1 (tabela 21) não houve diferenças $(P>0,1)$ nas concentrações médias de melatonina entre os tratamentos, entre as raças, 
entre os horários nem entre as interações. O fator animal dentro de tratamento e raça foi quase significativo $(P=0,1199)$ mostrando que há uma grande variação entre indivíduos, ficando difícil a detecção de diferenças entre raças ou qualquer outro fator. Vale ressaltar que não houve diferenças entre horários devido a exclusão dos dados diurnos nesta análise. Já era de se esperar que não houvesse diferenças entre tratamentos, pois neste período ainda não havia se iniciado os tratamentos nutricionais, indicando que antes do início dos tratamentos, os animais dos dois grupos apresentavam o mesmo padrão de secreção de melatonina.

Tabela 22. Resultados da análise de variância referente às concentrações plasmáticas de melatonina $(\mathrm{pg} / \mathrm{mL})$ de ovelhas das raças Santa Inês, Romney Marsh e Suffolk no período 2 (antes da introdução dos machos em 20/10/2001).

\begin{tabular}{ll}
\hline \multicolumn{1}{c}{ Causas de Variação } & Valores de P \\
\hline Tratamento (T) & $0,9252^{\text {ns }}$ \\
Raça (R) & $0,5096^{\text {ns }}$ \\
Interação T x R & $0,7913^{\text {ns }}$ \\
Animal dentro de (T x R) & $0,0845^{*}$ \\
Horário (H) & $0,1369^{\text {ns }}$ \\
Interação H x T & $0,2821^{\text {ns }}$ \\
Interação H x R & $0,8180^{\text {ns }}$ \\
Interação H x T x R & $0,5716^{\text {ns }}$ \\
\hline ns = não significativo; ${ }^{*} \mathrm{P}<0,1$ &
\end{tabular}


No período 2 (tabela 22), também não foram encontradas diferenças $(P>0,1)$ nas concentrações de melatonina devido ao tratamento, à raça, ao horário e às todas interações. As maiores diferenças encontradas foram devido ao fator animal $(P<0,1)$, ou seja, a variabilidade individual foi maior do que qualquer outro fator. De fato, a amplitude dos picos noturnos de melatonina parece ser muito variável entre indivíduos (MALPAUX et al., 1988; ARENDT, 1995), mas é estável dentro do mesmo indivíduo (ARENDT, 1995; CHEMINEAU et al., 1996). COELHO (2001) observou a mantença do padrão de secreção individual da melatonina ao longo do ano. Todos estes trabalhos sugerem que a concentração plasmática de melatonina é uma característica individual e que deve ser estudada sobre o ponto de vista genético. Realmente, ZARAZAGA et al. (1998) verificaram que a genética exerce uma forte influência nas concentrações plasmáticas de melatonina, com alta repetibilidade e herdabilidade $(0,42)$.

No período 3 (tabela 23) houve diferenças nas concentrações plasmáticas de melatonina devido ao tratamento $(P<0,1)$, ao horário $(P<0,001)$ e ao indivíduo $(P<0,1)$. Nesta fase, apesar da variação individual, foi possível detectar diferenças no perfil plasmático de melatonina devido ao horário e ao tratamento. Somente neste período (período 3) foram considerados todos os horários, sendo possível a detecção de diferenças de secreção devido ao horário, já que os maiores contrastes de secreção são entre as fases de luz e escura. 
Tabela 23. Resultados da análise de variância referente às concentrações plasmáticas de melatonina $(\mathrm{pg} / \mathrm{mL})$ de ovelhas das raças Santa Inês, Romney Marsh e Suffolk no período 3 (final do período experimental em 01/12/2001).

\begin{tabular}{lc}
\hline \multicolumn{1}{c}{ Causas de Variação } & Valores de P \\
\hline Tratamento (T) & $0,0879^{*}$ \\
Raça (R) & $0,2599^{\mathrm{ns}}$ \\
Interação T x R & $0,6540^{\mathrm{ns}}$ \\
Animal dentro de (T x R) & $0,0122^{*}$ \\
Horário (H) & $0,0001^{* * *}$ \\
Interação H x T & $0,1151^{\mathrm{ns}}$ \\
Interação H x R & $0,4309^{\mathrm{ns}}$ \\
Interação H x T x R & $0,6076^{\mathrm{ns}}$ \\
\hline \multicolumn{1}{c}{ ns = não significativo; ${ }^{*} \mathrm{P}<0,1 ;{ }^{* * *} \mathrm{P}<0,001$} &
\end{tabular}

De acordo com a figura 23, podemos observar o efeito do tratamento nutricional nas concentrações médias de melatonina, sendo superior $(P<0,1)$ nos animais suplementados $(70,83 \mathrm{pg} / \mathrm{mL})$ em relação aos não suplementados $(32,48 \mathrm{pg} / \mathrm{mL})$. Não foram encontrados na literatura trabalhos em ovinos relacionando concentrações plasmáticas de melatonina e nutrição. STOKKAN et al. (1991) e SELMAOUI et al. (2002) detectaram uma diminuição na secreção de melatonina em ratos submetidos à restrição alimentar. Porém, ainda não estão esclarecidos as conseqüências desta diminuição de melatonina na atividade cíclica reprodutiva em ovinos. Certamente uma restrição alimentar drástica poderá ocasionar efeitos deletérios na atividade 
reprodutiva, porém, NOTTER e CHEMINEAU (2001) associaram a seleção de ovelhas menos estacionais com menores concentrações plasmáticas de melatonina, em condições normais de nutrição.

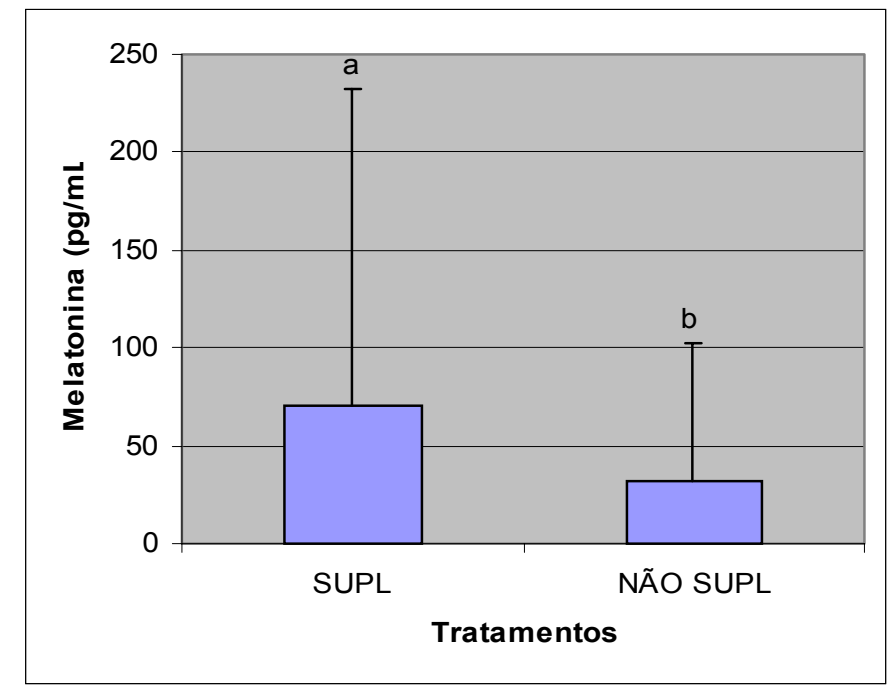

Figura 23. Médias e desvio padrão das concentrações plasmáticas de melatonina $(\mathrm{pg} / \mathrm{mL})$ no período $3(01 / 12 / 2001)$ de ovelhas das raças Santa Inês, Romney Marsh e Suffolk, de acordo com os tratamentos nutricionais (suplementadas e não suplementadas). Letras diferem pelo teste de Tukey $(\mathrm{P}<0,10)$.

$O$ fator raça não afetou $(P>0,1)$ as concentrações médias de melatonina no período 3, apesar das diferenças aparentes: 30,29 $\mathrm{pg} / \mathrm{mL}$ para SI, 49,07 $\mathrm{pg} / \mathrm{mL}$ para SU e 76,48 pg/mL para RM. Tais diferenças não foram detectadas pela análise de variância devido ao efeito do animal dentro da interação tratamento $\mathrm{x}$ raça (tabela 22). Essa variação imprime aos dados um coeficiente de variação elevado, o que impede a manifestação de diferenças quando poucos animais por tratamento e por raça são estudados. NOTTER e CHEMINEAU (2001) indicam que alta concentração plasmática de melatonina 
está relacionado com alto grau de estacionalidade reprodutiva, porém, este fato está relacionado a variabilidade individual e não a raça.

Apesar de não ter havido diferenças significativas $(P>0,1)$ na interação tratamento $\mathrm{x}$ raça, tais diferenças provavelmente não foram detectadas em função da variação individual. Quando analisadas separadamente cada raça, houve tendência dos animais suplementados apresentarem médias de concentrações de melatonina superiores aos animais não suplementados. Para as fêmeas Santa Inês, as diferenças entre tratamentos foram menos evidentes $(37,70 \mathrm{pg} / \mathrm{mL}$ vs. $22,88 \mathrm{pg} / \mathrm{mL})$. Maiores contrastes foram encontrados para as raças Romney Marsh e Suffolk com médias de 109,00 $\mathrm{pg} / \mathrm{mL}$ e $43,95 \mathrm{pg} / \mathrm{mL}$ para a primeira raça e $67,05 \mathrm{pg} / \mathrm{mL}$ e $31,09 \mathrm{pg} / \mathrm{mL}$ para a Suffolk, sempre o tratamento de suplementação apresentando as maiores médias.

Ainda, no período 3 , o horário foi um fator significativo para as concentrações plasmáticas de melatonina. As únicas diferenças encontradas foram nos horários 0:00, 2:00 e 4:00 h, sendo que o horário da 0:00 h e 2:00 h apresentaram as maiores concentrações médias de melatonina (figura 24). Esses resultados estão de acordo com vários trabalhos (ARENDT, 1995; COELHO, 2001), os quais têm demonstrado que as concentrações de melatonina são elevadas durante o período escuro e baixas na fase luminosa. Nos ovinos, as concentrações plasmáticas diurnas são baixíssimas (4 a 5 $\mathrm{pg} / \mathrm{mL}$ ), enquanto que as concentrações noturnas são bem elevadas, podendo variar de 100 a $700 \mathrm{pg} / \mathrm{mL}$ (ENGLISH et al., 1988; ARENDT, 1995; CHEMINEAU et al., 1996; COELHO, 2001). 
O pico, em geral, ocorreu às 0:00 horas. Isto está de acordo com ARENDT (1981) que evidenciou a existência de um pico noturno durante os dias longos, enquanto que nos dias curtos, foram observados dois picos.

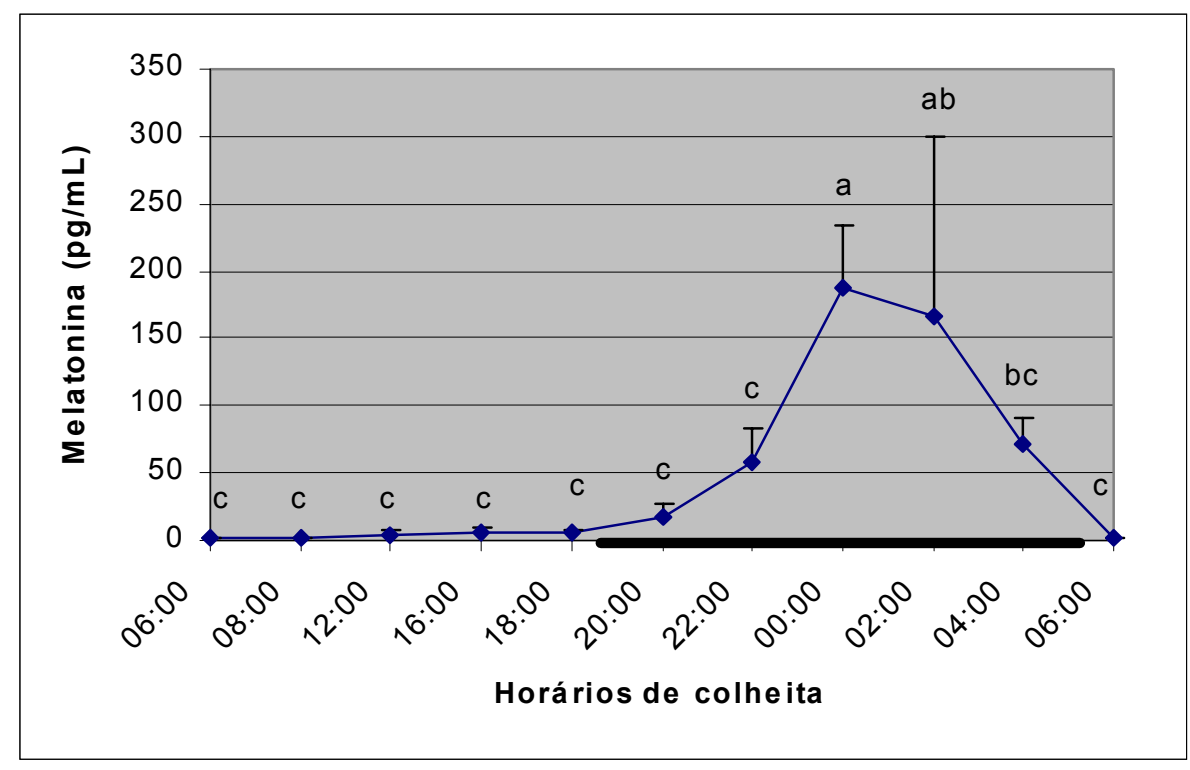

Figura 24. Concentrações plasmáticas médias de melatonina de ovelhas das raças Santa Inês, Romney Marsh e Suffolk, no período 3 (01/12/2001). Barra preta sob o eixo X representa a duração do escotoperíodo (período escuro). Letras diferem pelo teste de Tukey $(P<0,10)$.

Embora não tenha sido possível observar o efeito da interação tratamento $x$ horário $(P=0,1151$ ou $P>0,1)$, houve uma tendência (figura 25$)$ do tratamento de suplementação apresentar maiores concentrações médias, principalmente nos horários de maior secreção (horários noturnos). 


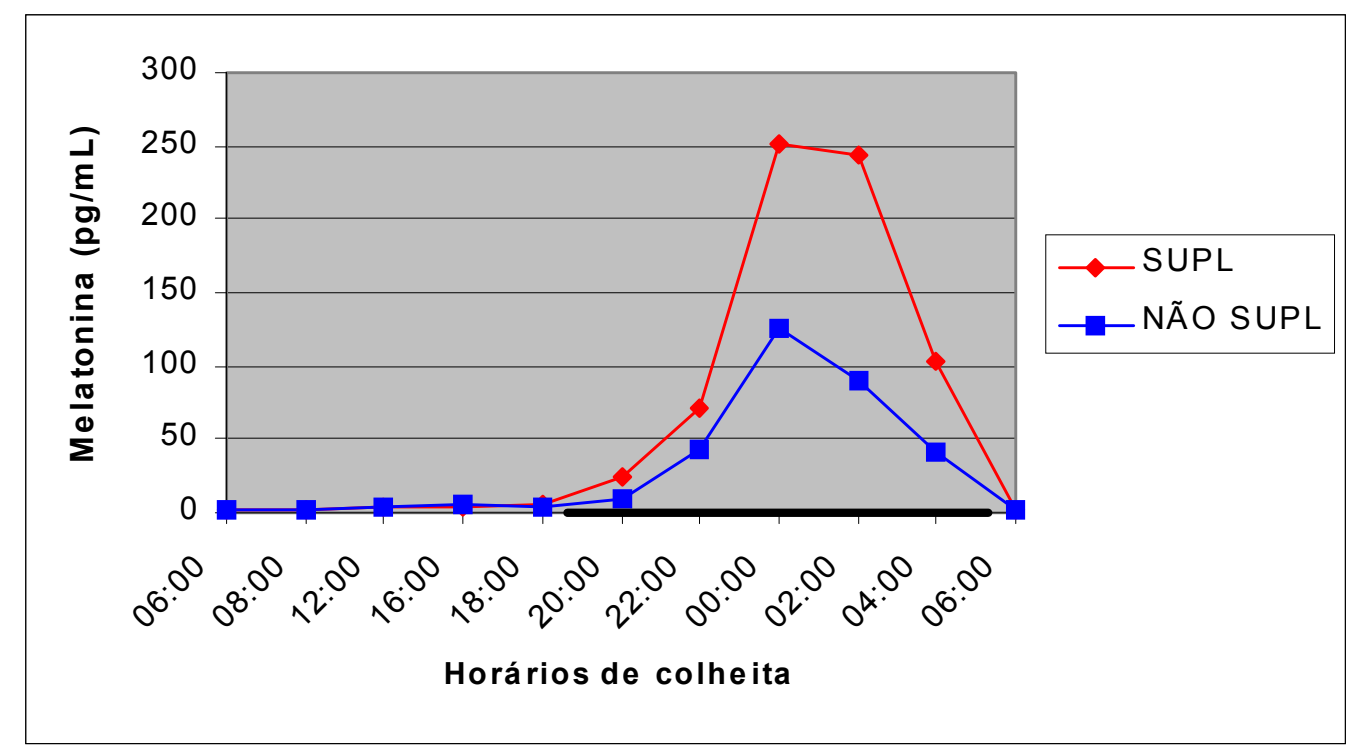

Figura 25. Médias das concentrações plasmáticas de melatonina $(\mathrm{pg} / \mathrm{mL})$ de ovelhas das raças Santa Inês, Romney Marsh e Suffolk, dentro de cada horário, por tratamento, no período 3 (01/12/2001). Barra preta sob o eixo X representa a duração do escotoperíodo (período escuro).

A interação horário $x$ raça também não foi significativa $(P>0,1)$, não apresentando diferenças no perfil diário médio das concentrações plasmáticas de melatonina entre as raças em cada horário (figura 26). As diferenças aparentes no gráfico no período noturno não são significativas devido a alta variabilidade dos dados e reduzido número de indivíduos dentro de cada raça. Porém, houve uma pequena tendência das fêmeas Romney Marsh apresentarem concentrações superiores à Santa Inês.

Considerando os horários estudados, as fêmeas Suffolk e Santa Inês apresentaram o pico médio de secreção $(182,84$ e $145,26 \mathrm{pg} / \mathrm{mL})$ às 0:00 
horas, enquanto nas fêmeas Romney Marsh esse pico $(295,56 \mathrm{pg} / \mathrm{mL})$ foi às 2:00 horas.

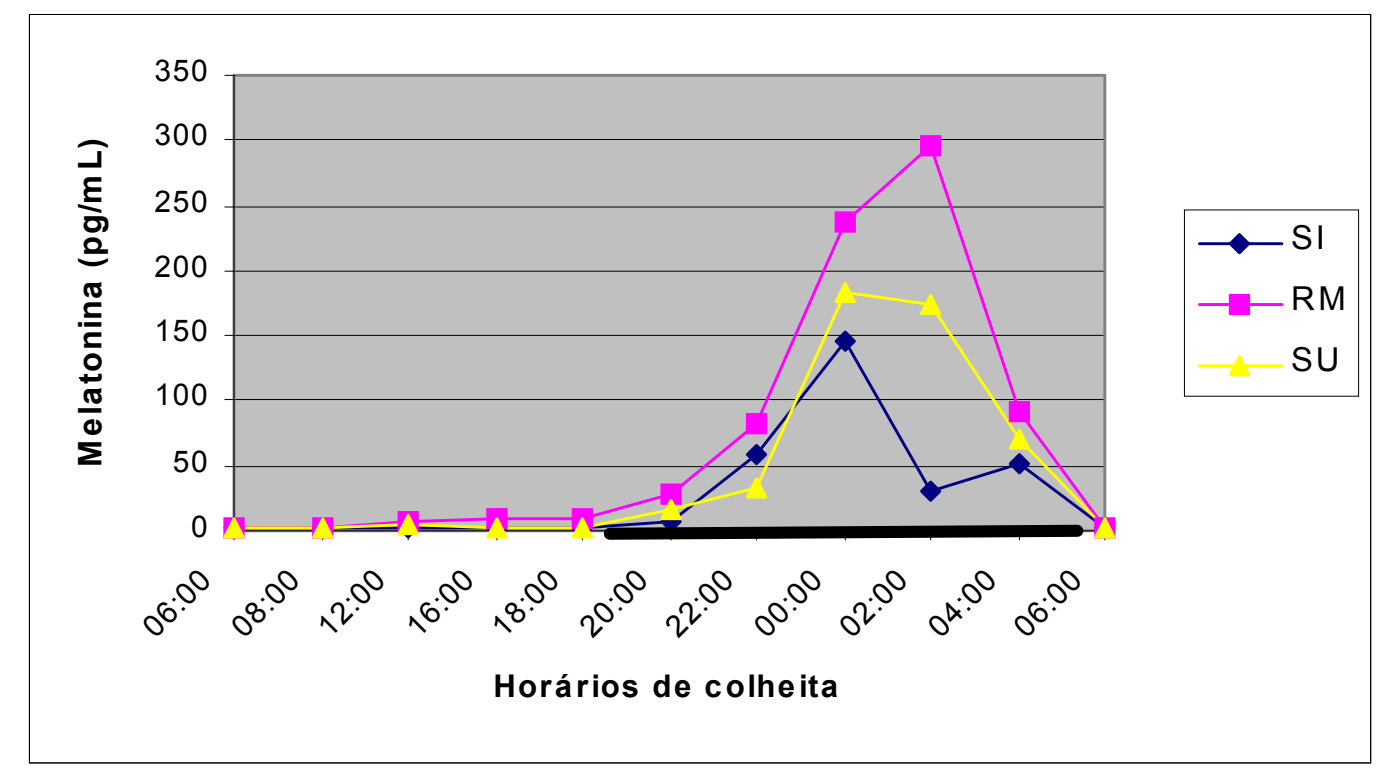

Figura 26. Média das concentrações plasmáticas de melatonina de ovelhas Santa Inês, Romney Marsh e Suffolk por horário, no período $3(01 / 12 / 2001)$. Barra preta sob o eixo $X$ representa a duração do escotoperíodo (período escuro).

A interação tripla tratamento $\mathrm{x}$ raça $\mathrm{x}$ horário também não foi significativa $(P>0,1)$, porém, novamente apresentou uma tendência de concentrações superiores do tratamento de suplementação no período noturno nas três raças (figura 27). 
A

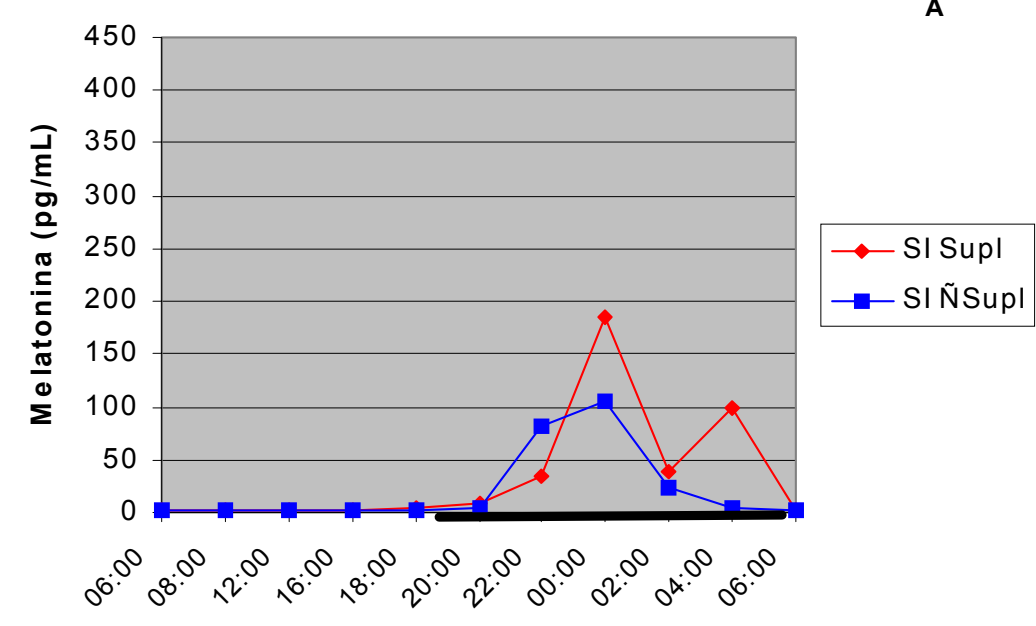

Horários de colheita

B

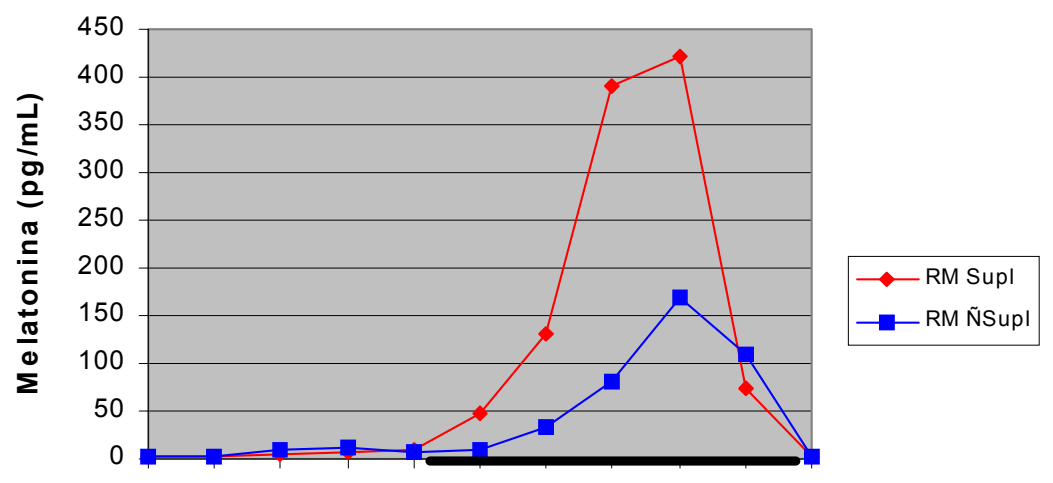

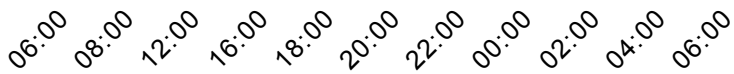

Horários de colheita

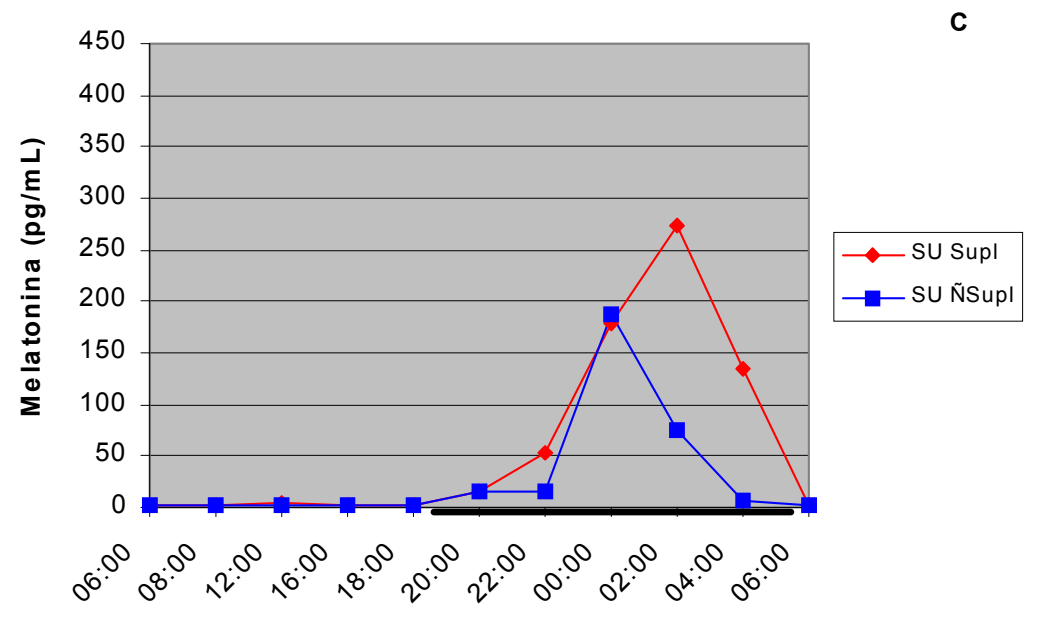

Horários da colheita

Figura 27. Perfil das concentrações plasmáticas de melatonina das raças Santa Inês (A), Romney Marsh (B) e Suffolk (C), por tratamento, no período $3(01 / 12 / 2001)$. Barra preta sob o eixo $X$ representa a duração do escotoperíodo (período escuro). 


\subsubsection{Duração (horas) e horários de início e término da secreção noturna de melatonina (horas)}

Devido ao padrão de secreção da melatonina apresentar uma relação crescente no início do escotoperíodo e uma relação decrescente no início da fase diurna, foi possível estimar o momento (horário) de início e de término da secreção noturna, através de uma regressão linear simples. E a partir disso, calculamos a duração da secreção noturna de melatonina

Desta forma, a tabela 24 expressa os resultados da análise de variância para a duração da secreção de melatonina.

Tabela 24. Resultados da análise de variância referente à duração da secreção noturna de melatonina (horas) observada em ovelhas Santa Inês, Romney Marsh e Suffolk no final do período experimental em 01/12/2001.

\begin{tabular}{ll}
\hline \multicolumn{1}{c}{ Causas de Variação } & Valores de P \\
\hline Tratamento (T) & $0,0125^{*}$ \\
Raça (R) & $0,8331^{\mathrm{ns}}$ \\
Interação T x R & $0,9446^{\mathrm{ns}}$ \\
\hline \multicolumn{1}{c}{ ns = não significativo; *P<0,1 }
\end{tabular}

Os tratamentos nutricionais proporcionaram durações de secreção de melatonina diferentes $(P<0,1)$ (figura 28), sendo 0 tratamento de suplementação superior (12,50 horas) que o de não suplementação $(8,80$ horas). 


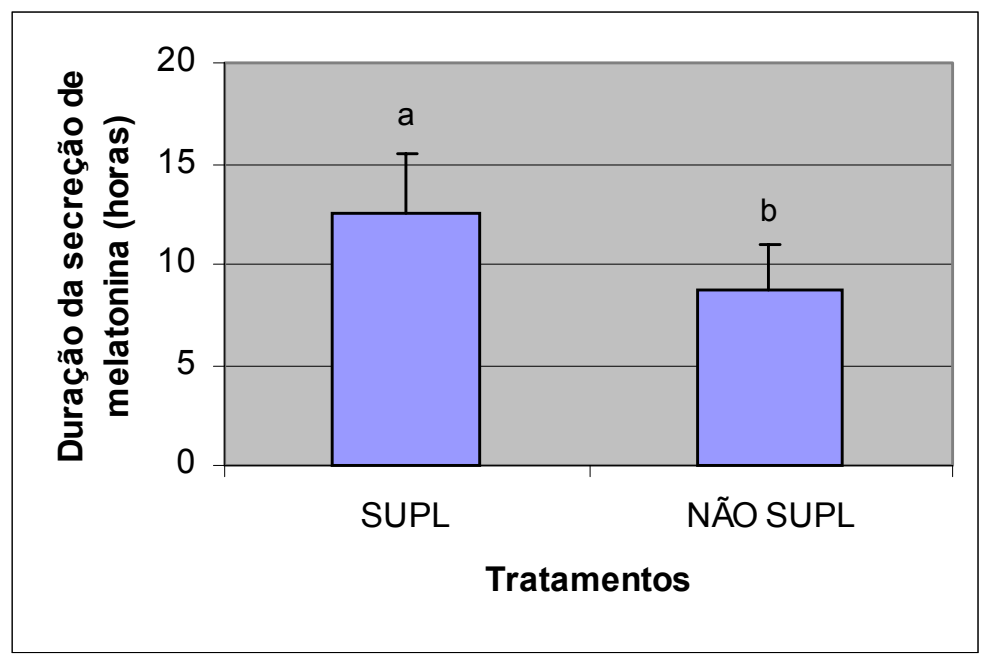

Figura 28. Médias e desvio padrão da duração da secreção noturna de melatonina (horas) em ovelhas das raças Santa Inês, Romney Marsh e Suffolk de acordo com os tratamentos de suplementação e não suplementação, no período 3 $(01 / 12 / 2001)$. Letras diferentes diferem pelo teste de Tukey $(P<0,10)$.

A duração média da secreção de melatonina ao longo do período de 24 horas não diferiu $(P>0,1)$ entre as fêmeas Santa Inês, Romney Marsh e Suffolk, sendo de 10,52; 11,23 e 10,30 horas, respectivamente. Isto está de acordo com COELHO (2001) e que também não encontrou diferenças entre estas raças ovinas na duração da secreção de melatonina, e que fatores como época do ano e indivíduo exercem maior influência que a própria raça do animal. Neste mesmo trabalho, a duração da secreção mínima foi no mês de dezembro (9,33 horas) e a máxima no de março (17,58 horas).

Os resultados da análise de variância para os horários de início e término da secreção noturna de melatonina estão expressos na tabela 25. 
Tabela 25. Resultados da análise de variância referentes ao horário de início (análise I) e de término (análise II) da secreção de melatonina observada em ovelhas Santa Inês, Romney Marsk e Suffolk no final do período experimental em $01 / 12 / 2001$.

\begin{tabular}{|c|c|c|c|}
\hline \multicolumn{2}{|c|}{ Análise I (início da secreção) } & \multicolumn{2}{|c|}{ Análise II (término da secreção) } \\
\hline Fontes de Variação & Valores de P & Fontes de Variação & Valores de P \\
\hline Tratamento $(\mathrm{T})$ & 0,0330 * & Tratamento $(\mathrm{T})$ & $0,0067^{* *}$ \\
\hline Raça (R) & $0,9413^{\mathrm{ns}}$ & Raça (R) & 0,0533 * \\
\hline Interação T x R & $0,7562^{\mathrm{ns}}$ & Interação T x R & $0,3670^{\mathrm{ns}}$ \\
\hline
\end{tabular}

Em relação ao horário de início da secreção de melatonina, somente o tratamento nutricional teve efeito $(P<0,1)$, já para o término da secreção, além do tratamento $(P<0,01)$, a raça $(P<0,1)$ também exerceu efeito. As interações tratamento $x$ raça não foram significativas $(P>0,1)$ nem para o início nem para $o$ término da secreção.

O início da secreção ocorreu em média às $17: 28 \mathrm{~h}$ para os animais suplementados e às $20: 10 \mathrm{~h}$ para os não suplementados (figura 29). A secreção de melatonina, para as fêmeas das três raças, teve início ao mesmo tempo, sendo às 18:32 h para a Santa Inês, às 18:49 h para Romney Marsh e às 19:01 h para Suffolk (figura 31). 


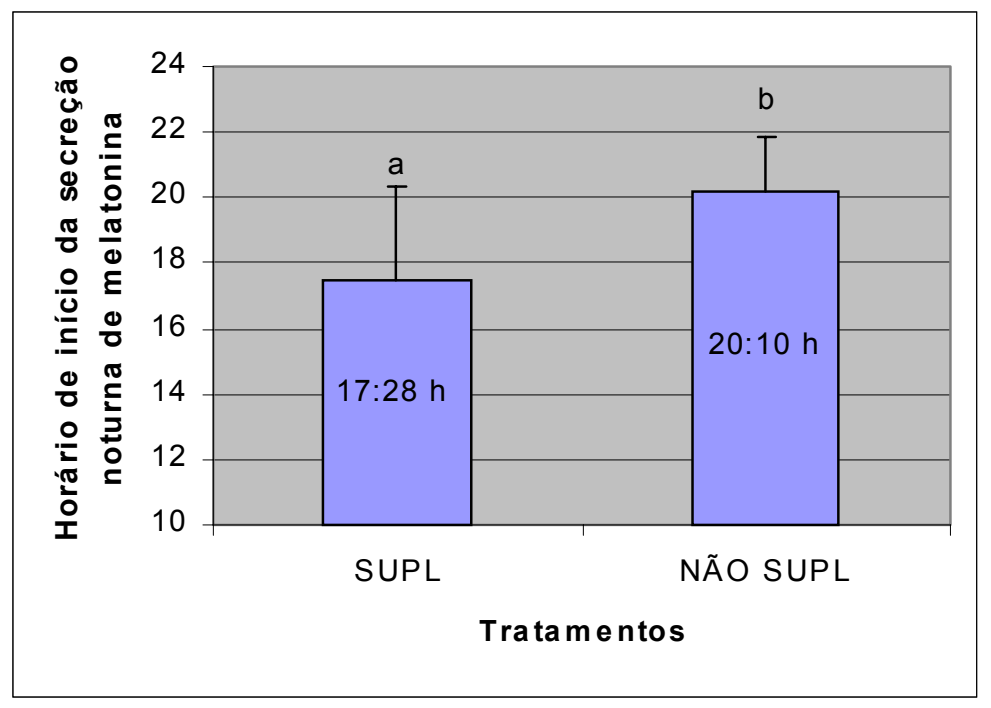

Figura 29. Início (horário) da secreção noturna de melatonina de ovelhas Santa Inês, Romney e Suffolk, de acordo com os tratamentos, no período $3(01 / 12 / 2001)$. Letras diferentes diferem pelo teste de Tukey $(P<0,10)$.

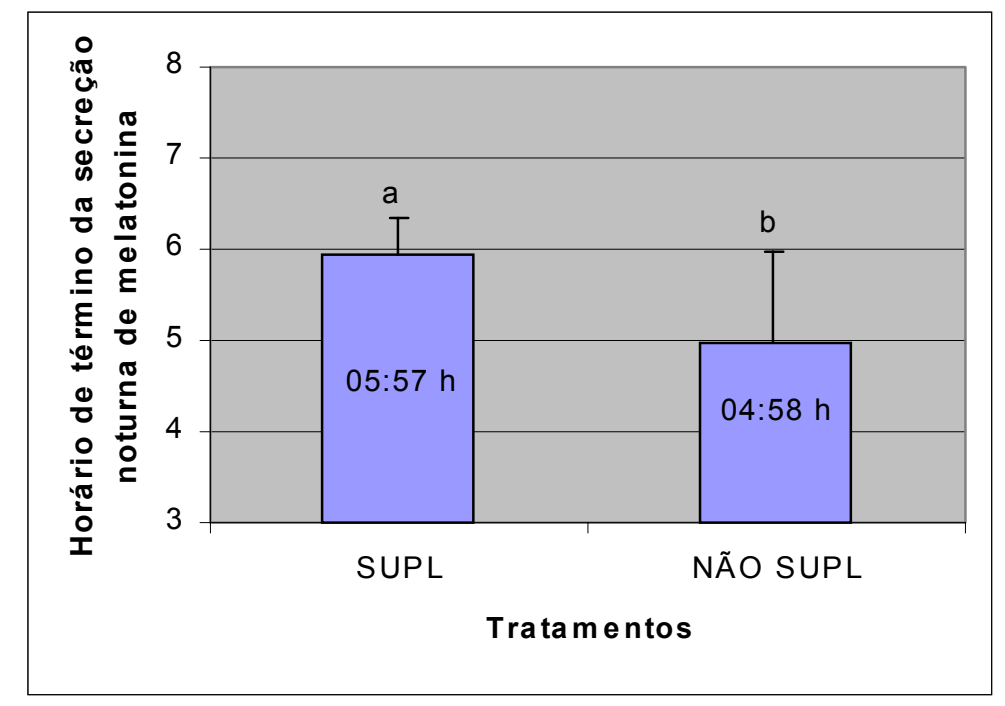

Figura 30. Término (horário) da secreção noturna de melatonina de ovelhas Santa Inês, Romney e Suffolk, de acordo com os tratamentos, no período $3(01 / 12 / 2001)$. Letras diferentes diferem pelo teste de Tukey $(P<0,10)$. 


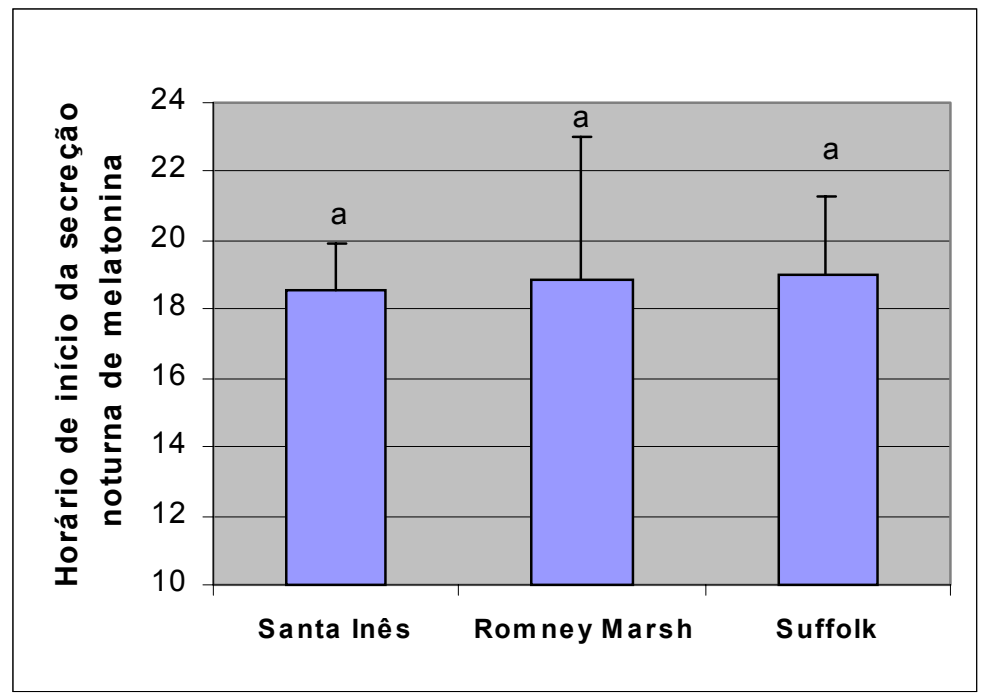

Figura 31. Início (horário) da secreção noturna de melatonina de ovelhas das raças Santa Inês, Romney e Suffolk, no período $3(01 / 12 / 2001)$. Letras diferentes diferem pelo teste de Tukey $(\mathrm{P}<0,10)$.

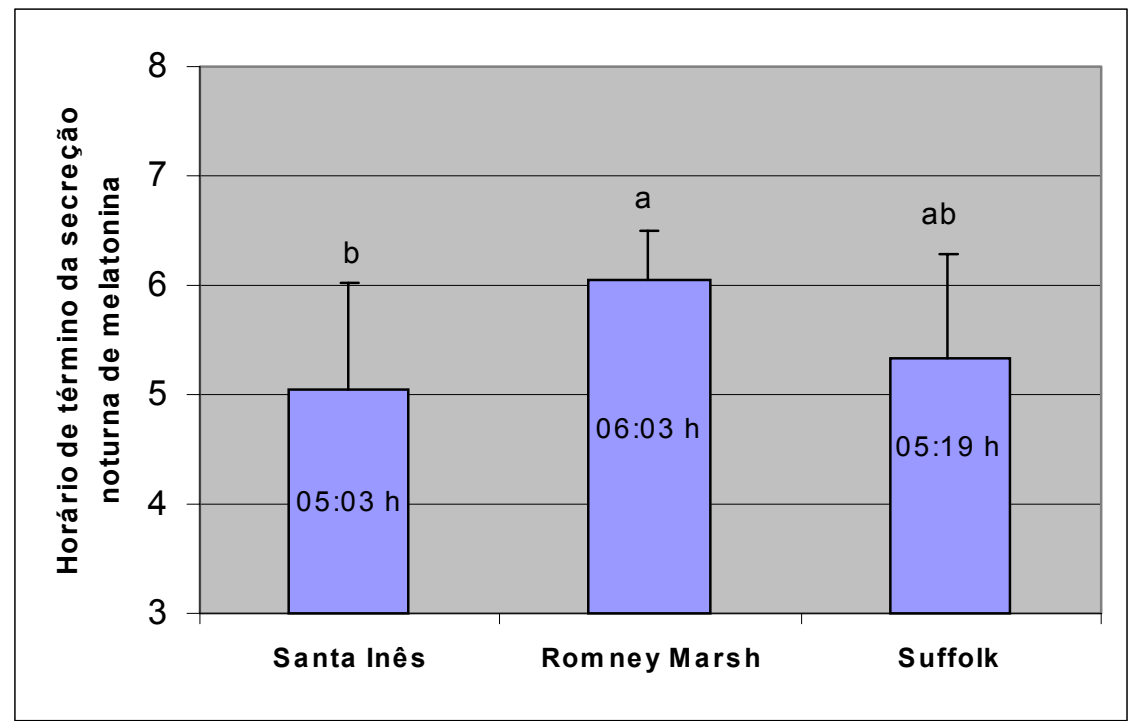

Figura 32. Término (horário) da secreção noturna de melatonina de ovelhas das raças Santa Inês, Romney e Suffolk, no período $3(01 / 12 / 2001)$. Letras diferentes diferem pelo teste de Tukey $(\mathrm{P}<0,10)$. 
O término da secreção ocorreu em média às $5: 57 \mathrm{~h}$ para os animais suplementados e às 4:58 h para os não suplementados (figura 30 ). De acordo com a figura 32, nas fêmeas Romney Marsh a secreção de melatonina encerrou, em média, às 6:03 $\mathrm{h}$, mais tarde $(P<0,1)$ que a das fêmeas Santa Inês (5:03 h) e Suffolk (5:19 h). Os horários médios do término da secreção dessas últimas fêmeas (Santa Inês e Suffolk) não diferiram $(P>0,1)$ entre si.

A duração média de secreção (10,68 horas) de todos animais praticamente coincidiu com a duração do escotoperíodo (10,80 horas). Este resultado está de acordo com COELHO (2001) e RODRIGUES (2001) que verificaram que a duração da secreção de melatonina foi maior que a duração do escotoperíodo na maioria dos meses do ano, exceto em novembro e dezembro, quando a duração dessa secreção foi igual à duração do escotoperíodo. O início médio (18:49 h) e o término médio (5:28 h) da secreção de melatonina também praticamente coincidiu com o início (18:34 h) e término (5:22 h) do escotoperíodo, sendo que a secreção se iniciou alguns minutos após o pôr do sol e se encerrou alguns minutos após o nascer do sol. Segundo CHEMINEAU et al. (1996) na espécie ovina ocorre um aumento súbito da melatonina circulante após início do escotoperíodo e a duração da secreção noturna da melatonina é proporcional à duração da noite, e que concentrações de melatonina caem a níveis basais antes ou imediatamente após o início do período diurno. Porém isto parece não ocorrer nas épocas de outono e inverno (MATTHEWS et al., 1992; COELHO, 2001). Já RODRIGUES et al. (2002) estudando a duração da secreção de melatonina ao longo do ano, verificou a existência de correlação entre duração da secreção de melatonina e incidência 
de estros nas raças Romney Marsh e Suffolk, o que não foi observado na Santa Inês (RODRIGUES et al, 2001). 


\section{CONCLUSÕES}

Nas condições em que foi realizado, o presente trabalho permite as seguintes conclusões:

As fêmeas Santa Inês apresentam um baixo grau de estacionalidade reprodutiva, e somente o efeito macho foi capaz de anular esta estacionalidade, independente das condições nutricionais.

Nas fêmeas Suffolk, o efeito macho promoveu parcialmente o retorno a atividade cíclica reprodutiva durante a época de anestro, sendo sua utilização recomendada no início ou no final do período de anestro. Nesta raça, o efeito macho, associado à nutrição pode amenizar a estacionalidade reprodutiva mesmo quando os animais perdem peso, mas a condição corporal é mediana.

Nas fêmeas raça Romney Marsh, com elevado grau de estacionalidade reprodutiva, a utilização do efeito macho, associado a nutrição, não foi capaz de promover o retorno da atividade cíclica reprodutiva.

As condições nutricionais do animal refletiram nas concentrações plasmáticas de melatonina, sendo menores em animais subalimentados.

A duração da secreção de melatonina das três raças coincidiram com o período de duração do escotoperíodo. Porém, diferenças foram encontradas devido à alimentação: animais subalimentados apresentaram duração de secreção menores que os alimentados nas exigências adequadas. As conseqüências destas mudanças na reprodução ainda não foram estudadas. 


\section{REFERÊNCIAS BIBLIOGRÁFICAS *}

ABECIA, J.A., FORCADA, F., ZARAZAGA, L. et al. The incidence of luteal activity, as determined by peripheral plasma progesterone concentration, before the onset of the breeding season in the Rasa Aragonesa breed of sheep. Braz. Vet. J., v. 152, p. 353-355, 1996.

ABOUL-NAGA , A.M.; ABOUL-ELA, M.B.; EL-NAKHLA, S.M. et al. Oestrus and ovarian activity of subtropical fat-tailed Rahmani sheep and their response to light treatment. J. Agric. Sci., v.108, p.617-621, 1987.

AKSOY, M.; TEKELI, T.; OZSAR, S. et al. Effect of ram introduction in combination with progesterone or cloprostenol on estrus induction rates of Konya Merino ewes in the anestrus season. Reprod. Dom. Anim., v.29, p.444-450, 1994.

ANUALPEC 2000 - Anuário da Pecuária Brasileira. São Paulo: Argos Comunicações, 2000.

ARENDT, J., SYMONS, A.M., LAUD, C.A. Pineal function in the sheep: evidence for a possible mechanism mediating seasonal reproductive activity. Experientia, v. 37, p. 584-86, 1981.

ARENDT, J.; SYMONS, A.M.; LAUD, C.A. et al. Melatonin can induce early onset of the breeding season in ewes. J. Endocrinol.,v.97, p.395-399, 1983.

ARENDT, J. Mammalian pineal rhythms. Pineal Res. Rev., v.3, p.161-213, 1985.

\footnotetext{
* De acordo com normas baseadas na ASSOCIAÇÃO BRASILEIRA DE NORMAS TÉCNICAS. Referências Bibliográficas: NBR 6023. Rio de Janeiro: ABNT, 1989. (Retirado de RODRIGUES, M.E.P; DONZENA, M.R. Programa de orientação aos usuários: serviços, pesquisa bibliográfica, referência bibliográfica. Pirassununga: FZEA/USP, 1999. 43p.)
} 
BARRELL, G.K.; THRUN, L.A.; BROWN, M.E. et al. Importance of photoperiodic signal quality to entrainment of the circannual reproductive rhythm of the ewe. Biol. Reprod., v.63, p.769-774, 2000.

BATHAEI, S.S. Breeding season and oestrous activity of Iranian fat-tailed Mehraban ewe lambs. Small Rum. Res., v. 22, p. 13-23, 1996.

CARVALHO, P.C.F.; POLI, C.H.E.C.; HERINGER, I. et al. Normas racionais de manejo de pastagens para ovinos em sistema exclusivo e integrado com bovinos. In: SIMPÓSIO PAULISTA DE OVINOCULTURA, 6. Botucatu, 2002. Anais... p. 21-50.

CheMineAU, P., BELTRÁN DE HEREDIA, I., DAVEAU, A. et al. High repeatability of the amplitude and duration of the nycthemeral rhythm of the plasma melatonin concentration in the lle-de-France ewe. J. Pineal Res., v. 21, p. 1-6, 1996.

COELHO, L.A.; RODRIGUES, P.A.; SASA, A. et al. Characteristics of oestrus cycle of wool and hair ewe lambs under tropical conditions in Brazil: preliminary results. In: INTERNATIONAL CONGRESS ON ANIMAL REPRODUCTION, 14, Stockholm, 2000a. Abstracts... v.1, p.278.

COELHO, L.A.; RODRIGUES, P.A.; SASA, A. et al. Concentrações plasmáticas de progesterona em borregas lanadas e deslanadas durante a estação reprodutiva. In: REUNIÃO ANUAL DA SOCIEDADE BRASILEIRA DE ZOOTECNIA, 37, Viçosa, 2000b. Anais... Viçosa: SBZ, p.153.

COELHO, L.A. Estudo sobre a atividade cíclica reprodutiva e o perfil plasmático de melatonina em fêmeas ovinas, sob fotoperíodo natural, no estado de São Paulo. Pirassununga, 2001. 127p. Tese (Livre Docência) - Faculdade de Zootecnia e Engenharia de Alimentos, Universidade de São Paulo, 2001. 
COELHO, L.A., RODRIGUES, P.A., SASA, A. et al. Breeding season length of wool and hair ewe lambs under subtropical conditions in Brazil. In: REUNIÓN DE LA ASOCIACIÓN LATINOAMERICANA DE PRODUCCIÓN ANIMAL, 17, Havana/Cuba, 2001. Anais..., Havana/Cuba, 2001. (Em CD ROM).

COELHO, L.A.; RODRIGUES, P.A.; NONAKA, K.O. et al. J. Annual pattern of plasma concentrations of melatonin in woll and hairless ewe lambs under natural photoperiod in southeast Brazil and their relationship with estrous incidence. In: EUROPEAN PINEAL \& BIOLOGICAL RHYTHMS SOCIETY SYMPOSIUM, 9, Aberdeen, 2002. Abstracts..., Aberdeen, 2002, p.96.

COGNIE, Y.; GRAY, S.J.; LINDSAY, D.R. et al. A new approach to controled breeding in sheep using the "ram effect". In: AUSTRALIAN SOCIETY OF ANIMAL PRODUCTION, 14, 1982. Proceedings..., 1982, p.519-522.

DUROTOYE, L.A. RAJKUMAR, R.; ARGO, C.M. et al. Effect of constantrelease melatonin implants on the onset oestrus activity and on reproductive performance in the ewe. Anim. Prod., v.52, p.489-497, 1991.

DYRMUNDSSON, Ó.R. Puberty and early reproductive performance in sheep.

I. Ewe lambs. Anim. Breed. Abstr., v.41, n.6, p.273-284, 1973.

DYRMUNDSSON, Ó.R. e LEES, J.L. Effect of rams on the onset of breeding activity in Clun Forest ewe lambs. J. Agric. Sci., v.79, p.269-271, 1972.

ELDON, J. Effect of exogenous melatonin and exposure to a ram on the time of onset and duration of the breeding season in Iceland sheep. J. Reprod. Fertil., v.99, p.1-6, 1993.

ENGLISH, J.; ARENDT, J.; SYMONS, A.M. et al. Pineal and ovarian response to 22 and 24 days in the ewe. Biol. Reprod., v.39, p.9-18, 1988.

ENGLISH, J.; POULTON, A.L.; ARENDT, J. et al. A comparison of the efficiency of melatonin treatment in advancing oestrus in ewes. J. Reprod. Fertil., v.77, p. 321-327, 1986. 
FERNANDES, F.M.N. A ovinocultura no contexto agropecuário paulista. In: SIMPÓSIO PAULISTA DE OVINOCULTURA, 5, Botucatu, 1999. Anais... p.07-09.

FIGUEIREDO, E.A.D.; OlIVEIRA, E.R.; BELLAVER, C. Performance de ovinos deslanados no Brasil. Sobral: EMBRAPA - CNPC, 1980. 32p. (Circular Técnica, 01).

FORCADA, F.; ZARAGAZA, L.; ABECIA, J.A. Effect of exogenous melatonin and nutrition after weaning on oestrus activity, endocrine status and ovulation rate in Salz ewe lambing in the seasonal anestrus. Theriogenology, p.1179-1193, 1995.

FRASER, A.F.; BROOM, D.M. Farm animal behaviour and welfare. 3ed.,CABI Publishing, 1997, 437p.

FRAZER, S.; COWEN, P.; FRANKLIN, M. et al. Direct radioimmunoassay for melatonin in plasma. Clin. Chem., v.29, p.396-397, 1983.

GALINA, M. A., MORALES, R., SILVA, E. et al. Reproductive performance of Pelibuey and Blackbelly sheep under tropical management systems in Mexico. Small Rumin. Res., v.22, p.31-37, 1996

GIRÃO, R.N., MEDEIROS, L.P., GIRÃO, E.S. Índices produtivos de ovinos da raça Santa Inês no Estado do Piauí. Teresina: EMBRAPA - UEPAE, 1984. $5 p$.

GOMEZ-BRUNET, A.; LÓPEZ SEBASTIAN, A.; PICAZZO, R.A. et al. Reproductive response and $\mathrm{LH}$ secretion in ewes treated with melatonin implants and induced to ovulate with the ram effect. Anim. Reprod. Sci., v.39. p.23-34, 1995.

GONZALEZ, R.; ORGEUR, P.; POINDRON, P. et al. Female effect in sheep. I. The effects of sexual receptivity of females and the sexual experience of rams. Reprod. Nutr. Dev., v.31, p.97-102, 1991. 
GORDON, I. Controlled reproduction in sheep and goats. v.2, Cambridge: CABI Publishing, 1997. 450p.

GUERIN, M.V.; WATSON, R.; McLOUGHNEY, J. et al. The annual patterns of serum melatonin in Romney Marsh sheep held in natural photoperiodic conditions. Adv. Pineal Res., v.3, p.137-141, 1989.

GUNN, R.G.; MAXWELL, T.J.; SIM, D.A. et al. The effect of level of nutrition prior to mating on the reproductive performance of ewes of two welsh breeds in different levels of body condition. Anim. Prod., v.52, p.157-163, 1991.

HAFEZ, E.S.E. Studies on the breeding season and reproduction of the ewe. J. Agric. Sci., v.42, p.189-265, 1952.

HAFEZ, E.S.E.; SCOTT, F.P. The behaviour of sheep and goats. In: HAFEZ, E.S.E. The behaviour of domestic animals. London: Baillière, Tindall \& Cox, 1962, p.297-333.

HANRAHAN, J.P.; O'RIORDAN, E.G. Exploiting the ram effect for early breeding: effect of ewe age and breed. J. Irish Grass. Anim. Prod. Assoc., v.24, p.105-108, 1990.

HARE, L., BRYANT, M.J. Characteristics of oestrous cycles and plasma progesterone profiles of young female sheep during their first breeding season. Anim. Prod., v. 35, p. 1-7, 1982.

HAYNES, N.B.; HARESIGN, W. Endocrine aspects of reproduction in the ram important to the male effect. World Rev. Anim. Prod., v.23, n.1, p.21-28, 1987.

HEAPE, W. The sexual season of mammals. Quartely J. Microsc. Sci., v.44, p.1-44, 1990.

HULET, C.V.; SHUPE, W.L.; ROSS, T. et al. Effects of nutritional environment and ram effect on breding season in range sheep. Theriogenology, v.25, p.317-323, 1986. 
JAINUDEEN, M.R.; HAFEZ, E.S.E. Sheep and Goat. In: HAFEZ, E.S.E. Reproduction in farm animals. 6ed. Philadelphia: Lea \& Fabiger, 1993. p.330-342.

JORDAN, B.T.; HANRAHAN, J.P.; ROCHE, J.F. The effect of melatonin implantation in the middle of the breeding season on the subsequent reproductive activity of Scottish Blackface ewes. Anim. Reprod. Sci., v. 23, p.41-48, 1990.

KARSH, F.J; BITTMAN, E.L.; FOSTER, D.L. et al. Neuroendocrine basis of seasonal reproduction. Rec. Prog. Horm. Res., v.40, p.185-232, 1984.

KOTT, R. Sheep nutrition. [on line] Disponível na internet via www.url http://agadsrv.msu.edu/Extension/Sheep/Handbook/nutr.html. Arquivo capturado em 30 de janeiro de 2001.

LALIOTIS, V.; VOSNIAKOU, A.; LYMBEROPOULOS, A. et al. The effect of melatonin treatment in combination with progestagen pessaries on the reproductive performance of the ewes during the anoestrous period. Anim. Sci., v.65, p.71-74, 1997.

LAMMING, G.E.; MANN, G.E. Control of endometrial oxytocin receptors and prostaglandin $\mathrm{F} 2 \alpha$ production in cows by progesterone and oestradiol. J. Reprod Fert., v.103, p.69-73, 1995.

LEGAN, S.J.;l'ANSON, H.; FITZ-GERALD, B.P. et al. Importance of short luteal phases in the endocrine mechanism controlling initiation of oestrus cucles in anestrous ewes. Endocrinology, v.117, p.1530-1536, 1985.

LINCOLN, G.A. Clinical trends and basic reserch in animal reproduction, Photoperiod-pineal-hypothalamic relay in sheep, Netherlands, 1992. p.203217.

LINDSAY, D.R. Reproduction in sheep and goat. In: CUPPS, P.T. Reproduction in domestic animals. 4ed. San Diego: Academic Press, 1991. P.491-515. 
LINDSAY, D.R.; SIGNORET, J.P. Influence of behaviour on reproduction. In: INTERNATIONAL CONGRESS ON ANIMAL REPRODUCTION, 9, Madrid, 1980. Abstracts... v.1, p.83-92.

MALPAUX, B., MOENTER, S.M., WAYNE, F.J. et al. Reproductive refractoriness of the ewe to inhibitory photoperiodic is not caused by alteration of the circadian secretion of melatonin. Neuroendocrinology, $v$. 48, p. 264- 270, 1988.

MALPAUX, B.; VIGUIÉ, C.; SKINNNER, D.C. et al. Control of rhythm os reproduction by melatonin in the ewe. Brain Res. Bull., v.44, n.4, p.431438, 1997.

MARTIN, G.B.; OLDHAM, C.M.; COGNIE, Y. et al. The physiological response of anovulatory ewes to the introduction of rams. Rev. Livest. Prod. Sci., v.57, p.219-247, 1986.

MATTHEWS, C.D., SEAMARK, R.F., GUERIN, M.V. Plasma melatonin profiles of Romney Marsh sheep in natural photoperiod and in acutely extended darkness. J. Reprod. Fertil., v. 95, p. 869-75, 1992.

McDONALD, L.E. Patterns of reproduction. In: McDONALD, L.E.; PINEDA, M.H. Veterinary Endocrinology and Reproduction. 4ed., London, p.389-398, 1989.

MIES FILHO, A. A patologia da reprodução na espécie ovina. In: MATERA, E.A.; GRUNERT, E.; MIES FILHO, A. Preleções sobre patologia da Reprodução. Belo Horizonte, p.280-345, 1975.

MINTON, J.E., COPPINGER, T.R., SPAETH, C.W. et al. Poor reproductive response of anestrous Suffolk ewes to ram exposure is not due to failure to secrete luteinizing hormone acutely. J. Anim. Sci., v. 69, p. 3314-20, 1991.

MORAES, J.C.F. Emprego do "efeito macho" na indução e manipulação do ciclo estral em ovelhas durante o anestro. A Hora Veterinária, v.11, p.3234, 1991. 
MUKASA-MUGERWA, E.; ANINDO, D.; LAHLOU-KASSI, A. et al. Seasonal variation in ovarian and oestrus activity of tropical Menz sheep as affected by plane of nutrition . Reprod. Nutr. Dev., v.33, p.585-595, 1993.

NATIONAL RESEARCH COUNCIL (NRC). Nutrient requeriments of domestic animals: nutrient requeriments of sheep. 6. ed. Washington: D.C., 1985. 99 p.

NEARY, M. Reproductive management of the ewe flock and the ram. [on line] Disponivel na internet via www.url http://ag.ansc.purdue.edu/sheep/articles/repromgt.html. Arquivo capturado em 30 de janeiro de 2001.

NOTTER, D.R. \& CHEMINEAU, P. Nocturnal melatonin and prolactin plasma concentrations in sheep selected for fertility in autumm lambing. J. Anim. Sci., v.79, p.2895-2901, 2001.

NOWAK, R.; RAJKUMAR, R.R.; WEBLEY, G.E. et al. Effect of prolonged exposure to exogenous melatonin on the onset and end of the breeding season and on the growth rate of ewe lambs. Brit. Vet. J., v.146, p.17-23, 1990.

NUGENT III, R.A.; NOTTER, D.R.; BEAL, W.E. Effects of ewe breed and ram exposure on estrous bahavior in May and June. J. Anim. Sci., v.66, p.1363-1370, 1988.

NUNES, J.F., FIGUEIRÓ, P.R.P. Fatores que afetam o comportamento reprodutivo em ovelhas Corriedale e Polwarth. R. Centro Ci. Rur., v.5,n.4, p.301-307, 1975.

OLDHAM, C.M.; PEARCE, D.T. Alternative methods for synchronization of ewes in spring using the "ram effect". In: AUSTRALIAN SOCIETY ANIMAL PRODUCTION, 15, 1984. Proceedings..., 1984, p.158-170. 
OTTO, C.; ANDRIGUETTO, J.L.; SÁ, J.L. et al. Estudo do "efeito macho" na concentração dos partos de ovelhas e borregas expostas à monta no anestro sazonal. In: REUNIÃO ANUAL DA SOCIEDADE BRASILEIRA DE ZOOTECNIA, 35, Botucatu, 1998. Anais... Botucatu:SBZ, 1998. p.163165.

PEARCE, D.T.; OLDHAM, C.M. The ram effect, its mechanism and application to the management of sheep. In: LINDSAY, D.R.; PEARCE, D.T. Reproduction in sheep. Australian Academy of Science:Canverra, p.2634, 1984.

PERKINS, A.; FITZGERALD, J.A.; PRICE, E.O. Luteinizing hormone and testosterone response of sexually active and inactive rams. J. Anim. Sci., v.70, p.2086-2093, 1992.

PINEDA, M.H. Reproductive patterns of sheep and goat. In: McDONALD, L.E. Veterinary endocrinology and reproduction. 4ed., Philadelphia: Lea \& Fabiger, p.428-447, 1989.

PÔRTO, M.S.C.S., TESTON, D.C., SASA, A. et al. Perfil plasmático de melatonina e atividade cíclica reprodutiva de ovelhas lanadas tratadas com implante de melatonina durante $O$ anestro estacional. In: SIMPÓSIO INTERNACIONAL DE INICIAÇÃO CIENTÍFICA DO ESTADO DE SÃO PAULO, 9, Piracicaba, ESALQ, 2001. Anais..., Piracicaba, 2001. (Em CD $\mathrm{ROM})$

PRUCOLLI, J.O., BACCARI Jr, F.L. Estudos sobre estação de monta em ovinos no Estado de São Paulo. . Bol. Ind. Anim., v.24, p.75-80, 1967.

QUIRKE, J.F. Onset of puberty and oestrus activity in Galway, Finnish Landrace and Finn-cross ewe lambs during their first breeding season. Irish J. Agric. Res., v. 17, p. 15-23, 1978.

REKIK, M.; BRYANT, M.J.; CUNNINGHAM, F.J. Effects of treatment with melatonin on the response of seasonally anovular ewes to the introduction of rams. Anim. Prod., v.53, p.203-207, 1991. 
RIBEIRO, E.L A., ROCHA, M. A. da, SILVA, L.F. da. Aspectos reprodutivos em ovelhas Hampshire Down submetidas à monta contínua na região Norte do Paraná. Rev. Soc. Bras. Zootec., v.25, n.4, p.637-646, 1996.

ROBINSON, J.J.; WIGZEIL, R.P.; AITKEN, J.M. et al. The modifying effects of melatonin, ram exposure and plane of nutrition on the onset of ovarian activity, ovulation rate and the endocrine status of ewes. Anim. Reprod. Sci., v.26, p.73-91, 1991.

ROBINSON, T.J. Estrus cycle of the ewe and doe. In: COLE, H.H.; CUPPS, P.T. Reproduction in Domestic Animals. Academic Press: New York, 1959. 59

RODA, D.S., SANTOS, L.E. dos, CUNHA, E.A. da, et al. Desempenho de ovinos em sistema de acasalamento a cada oito meses. Bol. Ind. Anim., v.50, n.01, p.49-54, 1993.

RODRIGUES, P.A.; COELHO, L.A.; NONAKA, K.O. et al. Padrão sazonal das concentrações plasmáticas de melatonina em borregas da raça Santa Inês, sob fotoperíodo natural, no sudeste do Brasil. In: CONGRESSO DE INTEGRAÇÃO EM BIOLOGIA DA REPRODUÇÃO, 2001, Ribeirão Preto. Anais..., Ribeirão Preto, 2001, p.83.

RODRIGUES, P.A. Avaliação da sazonalidade reprodutiva e perfil secretório de melatonina em ovelhas (Ovis aries) das raças Romney Marsh, Suffolk e Santa Inês. Botucatu, 2001. 82p. Tese (Doutorado) Faculdade de Medicina Veterinária e Zootecnia, Universidade estadual Paulista.

RODRIGUES, P.A.; COELHO, L.A.; SASA, A. et al. Duration of melatonin nighttime in wool and hairless ewe lambs under natural photoperiod in southeast of Brazil and its relationship with incidence of estrous. In: EUROPEAN PINEAL \& BIOLOGICAL RHYTHMS SOCIETY SYMPOSIUM, 9, Aberdeen, 2002. Abstracts..., Aberdeen, 2002, p.97. 
RODRIGUEZ-IGLESIAS, R.M.; CICCIOLI, N.H.; IRAZOQUI, H. Daily distribution of teaser-induced oestrus in Corriedale ewes injected with progesterone or MAP. Rev. Arg. Prod. Anim., v.12, n.1, p.65-70, 1992.

RONDON, Z.; FORCADA, F.; ZARAZAGA, L. et al. Oestrus activity, ovulation rate and plasma melatonin concentrations in Rasa Aragonesa ewes mainted at two different and constant body condition score levels and implanted or reimplanted with melatonin. Anim. Reprod. Sci., v.41, p.225236, 1996.

ROSA, H.J.D.; JUNIPER, D.T.; BRYANT, M.J. The effect of exposure to oestrus ewes on rams sexual behaviour, plasma testosterone concentration and ability to stimulate ovulation in seasonally anoestrus ewes. App. Anim. Behav. Sci., v.67, p.293-305, 2000.

SANFORD, L.M.; PALMER, W.M.; HOWLAND, B.E. Influence of sexual activity on serum levels of LH and testosterone in the ram. Can. J. Anim. Sci., v.54, p.579-585, 1974.

SASA. A., RODRIGUES, P.A., TESTON, D.C. et al. Incidência sazonal de estros em borregas lanadas e deslanadas criadas no Estado de São Paulo. In: REUNIÃO ANUAL DA SOCIEDADE BRASILEIRA DE ZOOTECNIA, 38, 2001, Piracicaba. Anais..., Piracicaba, 2001a, p.383-384.

SASA, A.; TESTON, D.C.; SILVA, E.C.F. et al. Perfil plasmático de progesterona e incidência mensal de ovulações silenciosas, em borregas lanadas e deslanadas criadas no Estado de São Paulo. In: CONGRESSO BRASILEIRO DE ZOOTECNIA - ZOOTEC, 21, 2001, Goiânia. Anais...Goiânia, 2001b, p.16.

SASA, A.; TESTON, D.C.; RODRIGUES, P.A. et al. Concentrações plasmáticas de progesterona em borregas lanadas e deslanadas durante $\mathrm{O}$ período de abril a novembro no Estado de São Paulo. Rev. Bras. Zootec., v.31, n.3, p.1150-1156, 2002. 
SELMAOUI, B.; OGUINE, A.; THIBAULT, L. Effect of food access schedule and dietary composition on nocturnal variations of serum melatonin and pineal NAT activity in rats. In: EUROPEAN PINEAL \& BIOLOGICAL RHYTHMS SOCIETY SYMPOSIUM, 9, Aberdeen, 2002. Anais..., Aberdeen, 2002, p.19.

SILVA SOBRINHO, A.G. Criação de Ovinos. Jaboticabal:FUNEP, 1997. $230 p$.

SILVA SOBRINHO, A.G.; BATISTA, A.M.V.; SIQUEIRA, E.R. et al. Nutrição de ovinos. Jaboticabal: FUNEP, 1996. 258p.

SILVA, A.E.D.F., NUNES, J.F. Estacionalidade na atividade sexual e qualidade do sêmen nos ovinos deslanados das raças Santa Inês e Somalis Brasileira. Sobral, EMBRAPA - CNPC, 1987. 14p.

SILVA, A.E.D.F., NUNES, J.F., SANCHEZ, O. et al. Efeito do manejo nutricional sobre a taxa de ovulação e folículos, no decorrer do ano, em ovinos deslanados no Nordeste do Brasil. Pesq. Agropec. Bras., v.22, n.6, p.635-645, 1987.

SILVA, O.L. da, FIGUEIRÓ, P.R.P. Efeito da época de cobertura sobre a fertilidade de ovelhas e mortalidade de cordeiros na raça Corriedale. In: REUNIÃO ANUAL DA SOCIEDADE BRASILEIRA DE ZOOTECNIA, 17, 1980, Fortaleza. Anais... Viçosa, 1980. P.127.

SIMPLÍCIO, A.A., RIERA, G.S., NELSON, E.A. et al. Seasonal variation in the seminal and testicular characteristics of Brazilian Somalis rams in the semiaris climate of tropical notheast Brazil. J. Reprod. Fertil., v.66, n.2, p.735738, 1982.

SIQUEIRA, E.R. Produção intensiva de cordeiros - confinamento. Viçosa, CPT, 2000. 56p.

SIQUEIRA, E.R. Integração é a chave do sucesso. Rev. Bras. Agrop., n.1, p.6-11, 2000.

STOKKAN, K.A.; REITER, R.J.; NONAKA, K.O. et al. Food restriction retards aging of pineal gland. Brain Res., v. 545, p.66-72, 1991. 
SUSIN, I. Exigências nutricionais de ovinos e estratégias de alimentação. In: SILVA SOBRINHO, A.G.; BATISTA, A.M.V.; SIQUEIRA, E.R. et al. Nutrição de ovinos, Jaboticabal: FUNEP, p.119-137, 1996.

THIMONIER, J., MAULÉON, P. Variations saisonnières du comportement dóestrus et des activités ovarienne et hypophysaire chez les ovins. Annales de Biologie Animale, Biochimie, Biophysique, v. 9, p. 223-250, 1969.

THIMONIER, J.; COGNIE, Y.; LASSOUED, N. et al. L'effet mâle chez les ovins: une technique actuelle de maltrise de la reproduction. Prod. Anim., v.13, p.223-231, 2000.

TRALDI, A.S. Produção de ovinos: aspectos reprodutivos dos ovinos. In: Performance reprodutiva dos ovinos deslanados no Brasil. FUNEP, Jaboticabal: 1990. p.81-124.

UMBERGER, S.H.; JABBAR, G.; LEWIS, G.S. Seasonaly anovulatory ewes fail to respond to progestagen treatment in the absrnce of gonadotropin stimulation. Theriogenology, v.42, p.1329-1336, 1994.

WALLACE, J.M.; ROBINSON, J.J.; WIGZELL, S. et al. Effect of melatonin on hte peripheral concentrations of $\mathrm{LH}$ and progesterone after oestrus, and on conception rate in ewes. J. Endocrinol., v.119, p.523-530, 1988.

WATSON, R.H.; RADFORD, H.M. The influence of rams on onset of oestrus in Merino ewes in the spring. Austr. J. Agric. Res., v.11, p.65-71, 1960.

ZARAZAGA, L.A., MALPAUX, B., BODIN, L. et al. The large variability in melatonin blood levels in ewes is under strong genetic influence. Endocrinol. Metab., v. 274, p. 607-610, 1998

ZARCO, L.; STABENFELDT, G.H.; QUIRKE, J.F.; KINDAHL, H.; BRADFORD. G.E. Release of prostaglandin F-2 $\alpha$ and the timing of events associated with luteolysis in ewes with oestrus cycles of different lenghts. J. Reprod. Fertil., v.83, p.517-526, 1988. 